\title{
2.2 Academic subjects / Studiengänge / Disciplines
}

\author{
ACADEMIC SUBJECT: \\ COUNTRY: \\ CITY, INSTITION:
}

\author{
Archive Science \\ France \\ Paris, Ecole Nationale des Chartes (p. 22)
}

07 Diplôme d'archiviste paléographe

08 Elèves fonctionnaires stagiaires/élèves non fonctionnaires.

09 Concours d'entrée. Admission sur titres possible pour les étudiants étrangers.

10 Du ler au 31 janvier de chaque année.

1116 octobre

12 L'Ecole des Chartes a pour mission la formation de personnels scientifiques des archives et des bibliothèques et contribue à la formation de tous les personnels ayant en charge le patrimoine national (décret du 8 octobre 1987).

14 lère année: Enseignements communs: Paléographie moderne, Philologie romane, Histoire et techniques du livre et de la gravure, Bibliographie, Institutions et archives de l'époque moderne, Archéologie et histoire de l'art (Moyen Age-XXe s.), Méthodes de l'histoire économique et sociale, Informatique. Filière médiévale et moderne: Paléographie médiévale, Latin médiéval, Diplomatique médiévale, Paléographie (libraria). Filière moderne et contemporaine: Institutions et sources d'archives, Institutions et archives contemporaines, Méthodes de l'histoire économique contemporaine, Critique de l'image documentaire. 2ème année: Enseignements communs: Paléographie moderne, Philologie romane, Histoire et techniques du livre, Institutions et archives de l'époque moderne, Histoire du droit, Archéologie et histoire de l'art (Moyen Age-XVIIIe siècle), Bibliographie et méthodes de documentation. Filière médiévale et moderne: Diplomatique et archivistique médiévales, Histoire et tradition manuscrite des textes littéraires, Critique de l'image documentaire. Filière moderne et contemporaine: Sources et techniques de l'histoire des entreprises, Systèmes de communication, Histoire de l'art du XIXe siècle, Critique de l'image documentaire. 3ème année: Enseignements communs: Edition et critique des documents diplomatiques, Méthodes de l'édition des textes romans, Traitement et interprétation des documents archéologiques, Méthodes modernes de documentation. Options: Histoire des institutions modernes, Archivistique contemporaine, Structures et archives des entreprises, histoire du droit, Histoire du livre imprimé, Histoire et tradition manuscrite des textes littéraires, Systèmes de communication et critique de l'image documentaire.

15 Stages ne sont pas prevus. 
16 Examens de fin d'année obligatoires pour être admis dans l'année supérieure. A l'automne qui suit la 3ème année, les élèves déposent une thèse qu'ils ont commencé à préparer à partir de la fin de la lère année.

17 Trois ans et neuf mois.

18 Corps des conservateurs du patrimoine; Corps scientifique des conservateurs de bibliothèques.

ACADEMIC SUBJECT: COUNTRY:

CITY, INSTITUTION:

\author{
Archive Science \\ Italy \\ Ravenna, Università degli Studi di Bologna, sede di \\ Ravenna (p. 48)
}

\section{Diploma in Archivistica}

09 I titoli di ammissione sono quelli previsti per l'ammissione ai corsi di laurea e cioè il diploma rieasciato da un Istituto d'istruzione secondaria superiore di durata quinquennale, nonchè a Istituti Magistrali e Licei artistici a condizione del superamento del corso annuale integrativo. In base alle strutture disponibili la Scuola è grado di accettare un numero massimo di iscritti determinati in 30 per ciascun anno di corso e per un totale di 90 studenti.

11 I candidati ammessi, in base alla graduatoria dovanno presentare, entro e non oltre il 10 ottobre, i documenti neccessari.

12 I corsi sono integrati da esercitazioni pratiche. Sono inoltre previsti seminari di esperti del settore e visite di studio ad attrezzature e sistemi biblioteconomici e archivistici. Per lo svolgimento delle attività didattiche la Scuola può avvalersi oltre che delle strutture universitarie anche di quelle enti di ricerca, anche stranieri, specializzati nel settore. E' ora la richiesta di conversione in corso di laurea breve secondo la legge sugli ordinamenti didattici pubblicata il 23 novembre 1990. Il nuovo curriculum, a carattere interdisciplinare, integrerà anche l'area della Logica e delle Filosofia della Scienza, Storia della Scienza, Principi di informatica, Fondamenti di informatica per le Scienze umane, Automazione degli Archivi e delle Biblioteche.

14 I Anno: Archivistica generale e storia degli archivi, Elementi di diritto per archivisti e bibliotecari, Latino medievale e umanistico, Paleografia latina, Storia bizantina, Storia medievale, Corso opzionale.

II Anno: Applicazioni tecnichi agli archivi e alle biblioteche, Diplomatica, Letteratura latina medievale, Archivistica speciale, Storia moderna, Una lingua straniera moderna, III Anno, Biblioteconomia, Storia contemporanea, Codicologia, Letteratura italiana, Una lingua straniera moderna, Corso opzionale. Corsi opzionali sono scelti dagli studenti tra quelli attivati dal seguente elenco: e.d., Ialettologia italiana; Diplomatica; Elementi di tecnica del restrauro del documento manoscritto; Esegi delle fonti della storia d'Italia; Esegi storico-giuridica del documento in età contemporanea; (...) in età medievale; (...) 
in età moderna; Filologia bizantina; (..) italiana; (...) medievale e umanistica; (...) romanza; Greco medievale; Latino; Litteratura greca medievale; (...) italiana moderna e contemporanea; Lingua francese; (...) greca; (...) inglese; spagnola; tedesca; Paleografia e diplomatica; (...) greca; (...) musicale; Papirologia; Science ausiliarie della storia; Tecnica dei cataloghi e classificazione

173 anni

18 Archivisti, bibliotecari, docenti di discipline storiche e storici professionali.

! la Rata (da pagarsi all'atto dell immatricolazione o iscizione): Matricole $=403.500 \mathrm{~L}$; Quota ridotta Matricole $=15.500 \mathrm{~L}$; Anni successivi $=341.500 \mathrm{~L}$.; fuori Corso $=$ 341.500 L.; 2a Rata (da pagarsi entro il 31 marzo): Matricole e anni successive in corso $=584.000 \mathrm{~L}$; ; Fuori Corso $=250.000 \mathrm{~L}$.

ACADEMIC SUBJECT: COUNTRY: CITY, INSTITUTION:

\author{
Archive Science \\ United Kingdom \\ London, University College of London (p. 88)
}

07 Diploma, Master of Arts (MA), Master of Philosophie (MPhil), Doctor of Philosophy $(\mathrm{PhD})$ in Archive Studies

08 2nd level; full-time, part-time

09 The course is open to candidates with a first or second class Honours degree from a British university, or the equivalent from an overseas university.

10 Deadline for enrolment is March 31 st of each year.

11 Studies start in October.

12 The course has been provided for three types of archivists: the traditional archivist employed in the United Kingdom who has to be able to deal with records dating from the eleventh century to the present day, the modern archivist who is concerned only with very recent records, and the archivist from overseas.

13 All students have to do four basic courses and Diploma students must in addition pass at least one examination in Administrative History and one on Paleography and Diplomatic.

14 Introduction to Automation; Record Office Management; Preparation of Finding Aids; Description of Documents; English Administrative History from c. 1100 to c. 1800 ; English administrative History from c. 1800; Overseas Administrative History; Medieval Palaeography and Diplomatic; Reading and Interpretation of Documents, Local Government Organization; Historical Sources, England and Wales; Historical and Bibliographical Sources; Business Archives; The Use of Computers in Record Offices. 
15 Pratical studies are intended.

16 The examination will consist of eight papers. An oral examination may also be required.

17 For full-time students: one year and for part-time students over two years.

! Composition fees due in any session become payable.

\author{
ACADEMIC SUBJECT: Archive Sciences \\ COUNTRY: \\ CITY, INSTITUTION: Loughborough, Loughborough University of \\ Technology (p. 90)
}

07 Master of Arts (MA), Master of Science (MSc), Diploma Loughborough University of Technology (DLUT) in Records Management \& Archives

08 2nd level; full-time, part-time

09 Applicants should have a good honours degree and about one year's experience (six week's minimum in exceptional circumstances), which can encompass a whole range of library or information-related jobs.

11 In October of each year.

12 This programme is intended for students who wish to pursue a career in Records Management, Archives, or Museum Documentalism. It looks at efficiently managing documents, in whichever form organizations have to create and use them in order to carry out their day-to-day operations. The programme aims to provide students with an understanding of the nature of the archive-creating process, both in the past and the present, and to provide a firm basis in the management and exploitation of archive collections of every kind, in the private as well as the public sector.

14 Records Management, Archive Administration, Preservation in Libraries and Archives, Information Handling, Information Management, optional modules: Health and Welfare Information Management, Human Factors in Information Systems Design, Local Studies Librarianship, Mass Media an Audio-visual Communication

16 Assessment for the MA or MSc degrees is by course-work and dissertation; for the DLUT by course-work and project report.

171 year full-time or 3 years part-time 
ACADEMIC SUBJECT: COUNTRY:

CITY, INSTITUTION:
Audiovisual Studies

France

Toulouse, Université Le Mirail-Toulouse II (p. 28)

07 lère année DEUP d'Etudes Audiovisuelles

Licence d'Etudes Audiovisuelles

Maîtrise d'Etudes Audiovisuelles

08 Temps plein

09 Etre titulaire de la lère année de DEUG ou équivalent et passer un concours.

10 Pré-inscription à faire avant le 20 juin.

11 Octobre

12 Préparation aux métiers de l'Audiovisuel: du Généraliste au Spécialiste. Cinq options: Ingénieur du son, Chef de la photographie, Conception générale, Infographiste, Architecture et décors. L'enseignement dispensé vise à offrir à tout étudiant la perspective d'être un jour "l'interface intelligente" d'une société, d'une entreprise ou d'une collectivité, capable d'allier la connaissance audiovisuelle aux questions techniques, scientifiques, culturelles à traiter.

13 lère année DEUP: 960 h; 2ème année Licence: 1270 h; 3ème année Maîtrise: 1350 h.

14 Expression audiovisuelle; Enseignements scientifiques fondamentaux; Technologie générale; Informatique; Langues; Information et Communication; Droit, Economie et gestion de l'audiovisuel; Technologie, pratiques et travaux; Esthétique; Réalisations.

15 Stages sont prevus.

16 Contrôle continu par module. Chaque étudiant conduira un projet personnel que sera évalué en 2 temps: étape de la recherche en fin de lère année, résultat de la recherche en fin de 2ème année. En ce qui concerne la Maîtrise, l'étudiant mènera son projet de recherche en fonction de la spécialité retenue et devra produire un mémoire d'au moins 200 pages dactylographiées pour accompagner sa production audiovisuelle.

173 années pour la Maîtrise

18 Métiers de l'Audiovisuel, Métiers de la Communication, etc. 
ACADEMIC SUBJECT: COUNTRY:

CITY, INSTITION:
Bibliographical Technics

France

Besançon, Université de Franche-Comté (p. 13)

07 Diplome d'Etudes Supérieures Spécialisées (DESS) en Bibliographie Informatisée

08 3ème cycle; temps plein ou temps partiel

09 Maîtrise et/ou DEA

10 Candidature: avant le 15 juillet; Inscriptions définitives: avant le 30 octobre.

11 Début 15 octobre

12 Finalité professionelle. Formation de personnels scientifiques (Laboratoires-InstitutsCentres de recherche ...) et Documentation-niveau Ingénieur.

13 Le semestre d'hiver est consacré aux enseignements. Appelé aussi "stage interne", il commence au début d'octobre par une session d'information/sélection à l'issue de laquelle le candidat est définitivement admis à s'inscrire en 3ème cycle pour cette formation. Dans la semaine suivant cette session, une mise à niveau intensive dans l'apprentissage de techniques de base informatiques est organisée avec les candidat(e)s retenu(e)s pour lesquel(le)s le jury estimerait ce complément de formation indispensable. Il se termine à la veille de Pâques par un examen comportant un écrit (3 épreuves) et un oral (2 épreuves).

Le semestre d'été est consacré au stage externe. Le candidat en choisit lui-même l'adresse selon ses meilleures possibilités personnelles. Le stage comporte d'une part une période de mise en route et d'initiation à l'organisme dans lequel le candidat a été admis; puis d'autre part une période active, au cours de laquelle il doit produire un travail original. Ce travail fait l'objet d'un "Mémoire" que le candidat rédige, qu'il soumet au jury de la formation et qu'il soutient devant lui avant la fin de l'année civile en cours.

14 Les cours portent sur les spécialités suivantes: Catalogage (rédaction des références); Abstracts (rédaction d'analyses); Bibliographie générale. Langages d'indexation et Thesaurus; Histoire et Epistémologie de l'Archive; Stratégie de la recherche d'information; Problèmes linguistiques et textuels; Informatique: La formation est organisée autour de deux types de machines: la gamme P.C. et la gamme Macintosh.

15 Le stage s'effectue pendant le deuxième semestre.

16 Examen de fin de stage interne (fin mars): Ecrit: Catalogage (rédation de références bibliographiques); Abstracts (rédaction de 2 résumés) $=$ Durée totale: 4 heures; Informatique (2 heures) Oral: Bibliographie (stratégie d'une recherche sur un sujet; bibliographie générale et spécialisée); Informatique 
171 an (temps plein) ou 2 ans (temps partiel)

18 Responsables Documentation/Recherche

$\begin{array}{lll}\text { ACADEMIC SUBJECT: } & \text { Book } & \text { Science } \\ \text { COUNTRY: } & \text { France } \\ \text { CITY, INSTITUTION: } & \text { Bordeaux, IUT de l'Université de Bordeaux II (p. 13) } & \text { Dijon, IUT de l'Université de Bourgogne (p. 15) } \\ & \text { Grenoble, IUT de l'Université de Grenoble II (p. 15) } \\ & \text { Nancy, IUT de l'Université de Nancy II (p. 20) } \\ & \text { Paris, IUTde l'Université René Descartes-Paris V (p.24) } \\ & \text { Paris, IUT de l'Université de Paris X (p. 27) }\end{array}$

07 Diplôme Universitaire de Technologie (DUT) option Métiers du Livre

08 ler cycle; temps plein

09 Sur dossier de candidature pour les titulaires du baccalauréat, d'un titre admis en équivalence ou sur validation des acquis.

10 Mois de juin au plus tard.

11 Vers le 15 septembre

12 Elle prépare les étudiants essentiellement au métiers des bibliothèques/médiathèques et du livre. Les étudiants doivent posséder une excellente connaissance du milieu interprofessionnel dans lequel s'exercera leur compétence.

13 Deux années de formation (voir ci-dessous)

14 Les bases théoriques, Le milieu professionel, La technologie de la profession, Le monde environnant, La mise en situation professionnelle.

15 Stage en deuxième année (10 semaines); stages à l'étranger sont possibles.

16 Système de contrôle continu.

172 années après le Bac, 1 année pour l'Année Spéciale

18 Bibliothèques des collectivités territoriales, Maisons d'édition, Librairies

! Tous les Départements Information-Communication d'IUT appliquent le même programme, qui est défini nationalement, et peuvent donc se décrire à peu près de la même façon. Ils peuvent comporter deux options: l'option "Documentation d'Entreprise" est ouverte dans 9 IUTs et l'option "Métiers du Livre" est ouverte seulement dans 6 IUTs. 


\section{ACADEMIC SUBJECT: Book Science \\ COUNTRY: \\ CITY, INSTITUTION: Mainz, Johannes-Gutenberg-Universität (p. 42)}

07 Magister Artium (MA), Doktor der Philosophie (Dr. phil.) der Buchwissenschaft

08 2. und 3. Ebene; Vollzeitstudium; das Fach Buchwesen kann als Haupt- und Nebenfach gewählt werden. Es kann mit allen historischen und literaturwissenschaftlichen Fächern, aber auch mit Jura und BWL studiert werden. Das Studium umfaßt im Hautpfach 58 und im Nebenfach 28 Semesterwochenstunden (SWS).

09 Allgemeine Hochschulreife oder ein gleichwertig anerkanntes Zeugnis; Latinum; zwei moderne Fremdsprachen

11 Zum Sommer- oder Wintersemester

12 Historische Buchforschung, Buch- Schrift- und Druckgeschichte

13 Das Studium gliedert sich in Grund- und Hauptstudium. Das Grundstudium vermittelt elementare Sach-, Problem- und Theoriekenntnisse, wissenschaftliche Arbeitstechniken, Hilfsmittel und Methodenkenntnisse. Das Hauptstudium gibt den Studierenden die Möglichkeit, sich fundierte Kenntnisse zu erwerben und in wissenschaftliche Spezialgebiete nach eigener Wahl einzuarbeiten.

14 Im Grundstudium: Handschriftenkunde, Schriftgeschichte, Typographie; im Hauptstudium: Druckgeschichte, Verlagsgeschichte, Autorbezüge

15 Praktika können sowohl im Grundstudium wie im Hauptstudium an Stelle von Übungen gewählt werden. Sie können in der eigenen Lehrdruckerei durchgeführt werden. Auslandspraktika werden empfohlen.

16 Zwischenprüfung nach dem vierten Semester; Magisterprüfung bzw. Rigorosum.

178 Semester Regelstudienzeit; die durchschnittliche Studiendauer beträgt 10 bis 12 Semester.

18 Lektoren, Journalisten, Hersteller im Verlag; Kustoden in Museen und Bibliotheken

\begin{tabular}{ll} 
ACADEMIC SUBJECT: & \multicolumn{2}{c}{ Business Information } \\
COUNTRY: & The Netherlands \\
CITY, INSTITUTION: & Deventer, Rijkshogeschool IJselland (p. 53)
\end{tabular}


08 1st level; full-time

09 A-level. No limitation (100 students each year).

10 First of December until first of June of each year.

11 First of September.

12 To train students as information specialists for business. Graduates of this programme can also establish themselves as independent information advisors or brokers.

13 The curriculum is divided into subject areas which are further sub-divided into modules. These are complete subject units which are concluded with a test. Every modul has a study load of 40 hours or a multitplication thereof; most are 80 hours.

14 Theory of Decision Making; Communication; Storage and Retrieval; Economics and Business; Information Science; Practical Training.

15 Practical studies are intended.

16 Exams at the end of each term.

17 Four years (eight terms).

18 Working environments also in large and medium businesses, corporate industrial organizations and organisational advisory bureaus and chambers of commerce.

ACADEMIC SUBJECT:

COUNTRY:

CITY, INSTITUTION:
Computing and Information Systems

United Kingdom

Bradford, University of Bradford (p. 83)

07 Bachelor of Science (BSc) Hons in Computing and Information Systems

08 1st level; full-time

09 Equivalent of mid range A-level scores (wide range of qualifications accepted).

10 Preferably by August 1st but not essential.

11 First of October

12 Our coures have three main objectives: to provide you with an awareness of the broad range of knowledge required in modern computing; to equip you with specialized knowledge required in the particular area of computing you wish to enter; to develop the analytical and personal skills you will require to make effective use of this knowledge 
when you obtain a job after graduation. Computing and Information Systems concentrate on the use of computing systems to handle information within a business environment.

13 Term modules, $3 \times 10$ week terms per year

14 Year One: Discrete Mathematics and Formal Specification; Human-Computer Interface; Logic Programming; Operating Systems; Software Construction; Year Two: Quantitative Analysis of Computer Systems; Software Engineering; Software Engineering Group Project; Information Systems Development; Decision Support Systems; Year Three: Proceed directly to Final Year; Final year: Real-Time Systems; Theory of Computing

15 Undergraduate courses contain a sensible balance of practical work (assessed by coursework); Practical studies can be carried out by supervised laboratory classes plus work (using computers) outside normal class hours; in industrial placement year students can work abroad.

16 Assessment by coursework plus examinations at the end of each term.

179 terms; 3 years or 4 years for courses with industrial placement year.

18 Graduates from our courses have in past obtained very interesting and responsible work; in both public and private sector, in manufacturing and in non-manufacturing or service industries. University of Bradford has excellent careers records. Initial salaries in 1990 ranged up to $£ 16,500$ with an average of $£ 11,375$.

! Accommodation fees will be supplied to you on a separate sheet, or may be obtained on request. But as a guide, in 1991-1992 fees at Revis Barber and Dennis Bellamy were approximately $£ 45$ per week, while fees in the self-catering halls were approximately $£$ 27 per week. Hall fees are likely to increase each year, and you should find out the latest situation when you need to know this. But fees at Bradford are generally lower than at other universities in the $\mathrm{UK}$, and are likely to remain so.

ACADEMIC SUBJECT:

\section{COUNTRY:}

CITY, INSTITUTION:
Computing and Information Systems

United Kingdom

Brighton, University of Brighton (p. 83)

07 Bachelor of Science (BA (Hons)), Diploma of Higher Education (DiphHE) in Computing and Information Systems

08 1st level; full-time, sandwich

09 Five GCSE, too at A-level or four at AS-level; English or mathematics at O-level or the equivalent; maximum number of students decided each year (currently 45 ).

10 August for September of each year; earlier application recommended as limit on numbers 
11 Autumn term end of September.

12 The course prepares the graduate for a career in which a sound knowledge of the theory and practice of computing is essential, and where there is particular emphasis on the ability to relate computer-based solutions to the wider needs of organizations, users and society in general.

14 The Information Environment: Human Organizations; Organizations at Work; Human/Computer Interaction; Management Techniques; System Analysis: The Nature of Systems, Structured Methodologies; Information Systems Analysis; Information Systems Design; Software Principles: Introduction to Software; Applications Programming; Data Bases; Applications Architecture; Information Technology; Data Processing Concepts; Technology Concepts; Computer Systems; Data Communication; Final year components: Information System Methodologies; IT Applications; plus two from: Auditing of Computer Systems; Data Management; Design of Complex Systems; Knowledge Based Systems; Marketing of IT; Software Trends; Project Management; Multimedia

15 Practical studies are intended; 12 month placement in year 3.

174 years sandwich-BA; 3 years full-time-BA; 2 years full-time-DipHE

18 System Analysis, Business Analysis, User Support, Technical Writing, Marketing, Training, Teaching, Technical Journalism, Electronic Publishing, Programming, Applications Development, Database Administration, Information Retrieval

! Students who have completed three years' ordinary residence within the EC will be assessed at the EC rate for fees purposes.

ACADEMIC SUBJECT:

COUNTRY:

CITY, INSTITION:

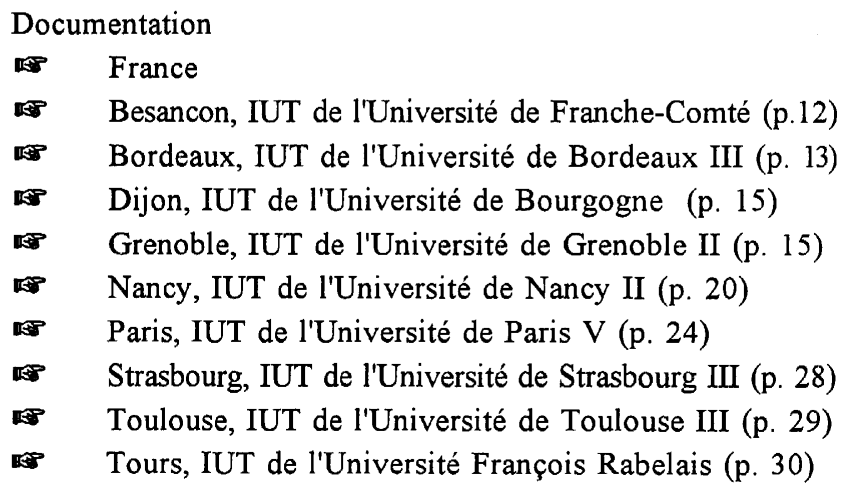

07 Diplôme Universitaire de Technologie (DUT) option Documentation d'Entreprise

08 ler cycle; Formation initiale à temps plein. 
09 Baccalauréat ou diplôme équivalent. Sélection sur dossier scolaire, tests écrits et entretien oral.

10 Mois de juin au plus tard.

11 Vers le 15 septembre.

12 Les futurs gestionnaires de l'information devront être des spécialistes polyvalents, capables de participer à la constitution d'une banque de données, mais aussi à l'analyse des besoins documentaires dans leur entreprise, tout comme à la mise en oeuvre de stratégies d'information.

13 Deux années de formation (voir ci-dessous).

14 Le programme s'organise autour de 8 modules: Le Culture Générale; La Connaissance du Monde Professionnel; Les Outils Méthodologiques et les Techniques; Le Traitement des Documents; La Recherche Documentaire; L'Informatique Documentaire; Le Management des Systems d'Information Documentaire; La Mise en Situation Professionnelle.

15 Deux stages obligatoires: 1 mois au moins en fin de lère année; 3 mois en fin de 2ème année. ler stage: Stage d'observation avec rapport de stage à rédiger. 2ème stage: Stage d'application avec rédaction d'un mémoire sur un projet en rapport avec le lieu de stage.

16 Modalités d'évaluation: Contrôle continu des connaissances sous forme de travaux écrits ou oraux, individuels ou de groupe, sur place ou en dehors de l'IUT. L'assiduité au cours et TP est obligatoire.

172 années après le Bac, 1 année pour l'Année Spéciale.

18 Documentaliste d'entreprise, secteur associatif, secteur privé, service public; Bibliothécaire spécialisé. Spécialiste de l'information. Iconographe

! Tous les Départements Information-Communication d'IUT appliquent le même programme, qui est défini nationalement, et peuvent donc se décrire à peu près de la même façon. Ils peuvent comporter deux options: l'option "Documentation d'Entreprise" est ouverte dans 9 IUTs et l'option "Métiers du Livre" est ouverte seulement dans 5 IUTs.

\begin{tabular}{lll} 
ACADEMIC SUBJECT: & \multicolumn{2}{c}{ Documentation } \\
COUNTRY: & France \\
CITY, INSTITUTION: & Lyon, Université Jean-Moulin-Lyon III (p. 18)
\end{tabular}

07 Certificat Attidude Professionnelles Etudes Supérieures de Documentation (CAPES) de documentation

08 2ème cycle; temps plein 
12 L'Université prépare aux deux épreuves écrites (dossier documentaire, épreuve à option) et aux épreuves orales (techniques documentaires et étude de cas). L'épreuve écrite á option correspond à une des épreuves d'admissibilité d'un de CAPES ou CAPET suivants: Lettres modernes, Histoire, Géographie, Langues vivantes (anglais) et Technologie. Seule la préparation à cette derniére option n'est pas assurée par l'Université JeanMoulin.

14 Documentation générale; Elaboration d'un dossier documentaire; Le centre de documentation et d'information et son environnement éducatif; Gestion et transfert de l'information-méthodes et techniques.

! Pour de plus amples informations sur le concours, se reporter au Bulletin officiel de I'Education Nationale.

ACADEMIC SUBJECT: COUNTRY: CITY, INSTITUTION:
Documentation

$\infty$ Germany

Hamburg, Fachhochschule Hamburg (p. 37)

07 Diplomdokumentar im Studiengang Mediendokumentation

08 1. Ebene; Vollzeitstudium

09 Fachhochschulreife oder allgemeine Hochschulreife oder fachgebundene Hochschulreife

10 1. Juni bis 15. Juli eines jeden Jahres (Ausschlußfrist); es können nur 30 Studenten im Jahr aufgenommen werden

11 Das Studium kann nur zum Wintersemester aufgenommen werden.

12 Mediendokumentation hat zum Ziel, auf unterschiedliche Medien fixierte Informationen zu beschaffen, zu sammeln, zu ordnen und wiederauffindbar zu machen, so daß sie für journalistische und redaktionelle Arbeit in Medieneinrichtungen genutzt werden können.

133 Semester Grundstudium, 1 Praxissemester und 4 Semester Hauptstudium

14 Strukturen und Konzepte des Mediensystems; Informationsmanagement und Informationstechnologie; Redaktionelle Praxis; Informationsarbeit und Informationsdienstleistungen; Fachwissenschaftliche Grundlagen der Mediendokumentation

15 Im 4. Semester ist ein Praxissemester in einer externen Mediendokumentationsstelle und im 6. Semester ein fachpraktisches Projekt in Zusammenarbeit mit einer externen Einrichtung abzuleisten.

178 Semester (Regelstudienzeit) 
18 Bisher noch keine Absolventen.

! Das Studium kann erstmals im Wintersemester 1993/94 aufgenommen werden.

$\begin{array}{ll}\text { ACADEMIC SUBJECT: } & \text { Documentation } \\ \text { COUNTRY: } & \text { Germany } \\ \text { CITY, INSTITUTION: } & \text { Hannover, Fachhochschule Hannover (p. 38) }\end{array}$

07 Diplomdokumentar (FH) im Studiengang Allgemeine Dokumentation

08 1. Ebene; Vollzeitstudium

09 Studienberechtigt sind Bewerberinnen und Bewerber mit allgemeiner oder fachgebundener Hochschulreife, mit Fachhochschulreife, bestandener Immaturenprüfung oder einer beim Kultusminister als gleichwertig anerkannten Vorbildung.

11 Wegen begrenzter Studienkapazität und hoher Bewerberzahlen ist die Zulassung in der Regel beschränkt. Sie erfolgt jeweils zum Wintersemester nach den für Numerus-claususFächern geltenden Rechtsvorschriften durch das Immatrikulationsamt der FH Hannover. Ausländische Interessenten erfahren die für sie geltenden Zulassungsbedingungen beim Institut für ausländische Fachhochschulbewerber. Das Studium wird zum 21. September aufgenommen. Bewerbungsschluß ist der 15. Juli.

12 Der Studiengang "Allgemeine Dokumentation" vermittelt neben bibliothekarischem Grundwissen eine umfassende dokumentationsmethodische Ausbildung, die den Absolventen mit dem Titel "Diplomdokumentar" den Zugang zu Berufsfeldern öffnet, in denen die effektive Handhabung von Informationen unter Einsatz modernster und rationellster Methoden ein wesentliches Element ist.

13 Das Studium gliedert sich in ein zweisemestriges Grund- und ein sechssemestriges Hauptstudium.

14 Pflichtfächer im Grundstudium: Betriebslehre der IuD-Einrichtung; Formale Erfassung; Grundlagen der inhaltlichen Erschließung; Grundlagen der Informationsvermittlung; Grundlagen der Informatik; Deskriptive Statistik, Informationssoziologie und -psychologie. Von den Wahlpflichtfächern muß eines gewählt werden: Grundlagen des Rechts des Bibliotheks- Informations- und Dokumentationswesens; Buchbinden, Druck- und Reprotechnik; Fachenglisch. Pflichtfächer im Hauptstudium: Informationssysteme; Theorie und Praxis der inhaltlichen Erschließung; Theorie und Praxis der Informationsvermittlung; Informatik (Programmieren); Daten- und Faktendokumentation; Informationsmanagement; Analytische Statistik; Organisation des Bibliothekswesens. Von den Wahlpflichtfächern müssen drei gewählt werden: Ausgewählte Fragen der Informatik; Produktion und Präsentation von Informationsdienstleistungen; Angewandte Informationsvermittlung; Informationsrecht; Ausgewählte Fragen der Wissensverarbeitung; Wissenschaftskundlicher Vertiefungsbereich; Fachsprachen. 
15 Das vierte Semester ist als Praxissemester in einer Informations- und Dokumentationsstelle, einer Bibliothek oder einer Technischen Dokumentationsabteilung zu absolvieren. Das siebte Semester kann als Praxissemester auch im Ausland durchgeführt werden.

16 Diplomvorprüfung am Ende des 2. Semesters. Diplomprüfung im 8. Semester. Die Prüfungen sind teilweise während des Studiums abzuleisten.

178 Semester

18 Diplomdokumentare können überall da eingesetzt werden, wo es gilt, Informationen jeder Art zu sammeln, zu strukturieren, zu speichern und zu vermitteln. Die Einsatzbereiche reichen dabei von Fachinformationszentren für Fachliteratur bis zu Banken und BTXAgenturen, vom betriebsinternen Informationsmanagement bis $\mathrm{zu}$ internationalen, wissenschaftlich-technischen Verbundsystemen. In jedem Fall sind Flexibilität und Gespür für die Auswahl adäquater Techniken der Informationsaufbereitung und -verarbeitung gefragt.

\section{ACADEMIC SUBJECT: COUNTRY:} CITY, INSTITUTION:

\author{
Documentation \\ 1 Germany \\ Hannover, Fachhochschule Hannover (p. 38)
}

07 Diplomdokumentar (FH) im Studiengang Biowissenschaftliche Dokumentation

08 1. Ebene; Vollzeitstudium

09 Studienberechtigt sind Bewerberinnen und Bewerber mit allgemeiner oder fachgebundener Hochschulreife, mit Fachhochschulreife, bestandener Immaturenprüfung oder einer beim Kultusminister als gleichwertig anerkannten Vorbildung.

10 Bis zum 15. Juli eines jeden Jahres.

11 Wegen begrenzter Studienkapazität und hoher Bewerberzahlen ist die Zulassung in der Regel beschränkt. Sie erfolgt jeweils zum Wintersemester nach den für Numerus-claususFächern geltenden Rechtsvorschriften durch das Immatrikulationsamt der FH Hannover. Ausländische Interessenten erfahren die für sie geltenden Zulassungsbedingungen beim Institut für ausländische Fachhochschulbewerber. Das Studium wird zum 21. September aufgenommen.

12 Im Mittelpunkt der Ausbildung steht der dokumentarische Aspekt. Die Einbeziehung eines Ausbildungsschwerpunktes Biowissenschaften dient der Schaffung von fachwissenschaftlichen Grundlagen für die Bewältigung spezifischer Dokumentationsprobleme im biowissenschaftlichen Bereich. Demzufolge erfolgt schwerpunktmäßig die Vermittlung elementarer biologischer und medizinischer Kenntnisse, nicht jedoch die Vermittlung systematischen Detailwissens. Die Entscheidung zum Studium sollte deshalb nicht vorrangig von speziellen medizinischen oder biologischen Interessen abhänigig gemacht werden. Sie sollte vielmehr berücksichtigen, daß nach dem Abschluß des Studiums 
ausschließlich dokumentarische Tätigkeiten ausgeübt werden. Dabei spielen umfassende anwendungsbezogene Kenntnisse in den Fächern Informatik und Statistik eine zentrale Rolle.

13 Das Studium gliedert sich in ein zweisemestriges Grund- und ein sechssemestriges Hauptstudium.

14 Pflichtfächer: Biowissenschaften; Betriebslehre der BID-Einrichtungen; formale Erfassung; inhaltlichen Erschließung; Informationsvermittlung; Informationsmanagement; Informationssysteme; Datenverarbeitung/Informatik; Statistik/Biometrie; Spezielle Datendokumentation in den Biowissenschaften; Projektarbeit. Von den Wahlpflichtfächern müssen fünf gewählt werden: Klinische Dokumentation; Praktisches Erstellen von Programmen; Mikrobiologie und Biotechnologie; Physiologische Chemie; Datenbankpraktikum; Datenbanken auf PC; Seminar zur angewandten Informationsvermittlung; Methoden der klinischen Statistik; Spezielle Pharmakologie; Ökologie; Klinische Pharmakologie.

15 Das vierte Semester ist als Praxissemester in einer Informations- und Dokumentationsstelle, einer Bibliothek oder einer Technischen Dokumentationsabteilung zu absolvieren. Das siebte Semester kann als Praxissemester auch im Ausland durchgeführt werden.

16 Diplomvorprüfung am Ende des 2. Semesters. Diplomprüfung im 8. Semester. Die Prüfungen sind teilweise während des Studiums abzuleisten.

\section{Semester}

18 Derzeit können die Ausbildungsstätten den Bedarf des öffentlichen Dienstes und der Industrie nicht ausreichend decken. Aufgrund des Fehlens tarifvertraglicher Festlegungen ist die Vergütung nicht einheitlich. Im öffentlichen Dienst sollte jedoch mindestens eine Vergütung nach BAT IV a erfolgen. In der Industrie liegen die Anfangsgehälter bei ca. 3500 DM, Spitzengehälter erfahrener biowissenschaftlicher Dokumentare bei ca. 6000 DM.

ACADEMIC SUBJECT: COUNTRY: CITY, INSTITUTION:

\author{
Documentation \\ IP Germany \\ Potsdam, Fachhochschule Potsdam (p. 42)
}

07 Diplomdokumentar (FH)

08 1. Ebene; Vollzeitstudium

09 Allgemeine Hochschulreife/Fachhochschulreife. Es gibt Zulassungsbeschränkungen.

10 Im Mai-Juni eines jeden Jahres.

11 Wintersemester 
12 Ausbildung von Diplomdokumentaren für Wissenschaft und Wirtschaft.

13 Das Studium ist gegliedert in Grund- und Hauptstudium. Pflichtnebenfach ist Archivoder Bibliothekswesen.

15 Insgesamt acht Monate Praktikum müssen während des Studiums abgeleistet werden. Es gibt die Möglichkeit zu Auslandspraktika.

16 Zwischenprüfung nach den 4. Semester einschließlich einer praktischen Arbeit, am Ende des Studiums steht die Diplomprüfung.

178 Semester Regelstudienzeit

ACADEMIC SUBJECT:

COUNTRY:

CITY, INSTITUTION:

\section{Documentation}

\section{(E) Germany}

Stuttgart, Fachhochschule für Bibliothekswesen (p. 46)

07 Diplomdokumentar

08 1. Ebene; Vollzeitstudium

09 Fachhochschulreife

11 Mitte Oktober

12 Handlungskompetenz für alle Aufgaben der Informationsvermittlung zur selbständigen Erledigung mit Ausnahme der Referate-Erstellung.

13 Das Studium gliedert sich in Grundstudium (1. u. 2. Semester), praktisches Studiensemester (3. Semester) und Hauptstudium (4. bis 7. Semester).

14 Informationswesen, Betriebslehre, Medien- und Informationsbeschaffung, Aufbau von Datenbanken und Wissensbasen, Datenverarbeitung, Infometrie und Statistik, Informationsvermittlung, fachorientierte Informationserschließung und -vermittlung, Recht, FachEnglisch, Technik des wissenschaftlichen Arbeitens. Das Studienangebot umfaßt Pflichtfächer und das Wahlpflichtfach "Fachorientierte Informationserschließung und -vermittlung".

15 Ein praktisches Studiensemester und 8 Wochen zwischen den Semestern, die Einweisung zu den Praktikumsstellen erfolgt durch die Fachhochschule.

16 In jedem Semester sind Prüfungen mündlicher und/oder schriftlicher und/oder praktischer Form abzulegen. Am Ende des Studium muß eine Diplomarbeit angefertigt werden.

$17 \quad 7$ Semester

18 Diplomdokumentar in IuD-Stellen 
ACADEMIC SUBJECT:

COUNTRY:

CITY, INSTITUTION:

\author{
Documentation \\ Portugal \\ Coímbra, Universidade de Coímbra (p. 62)
}

07 Diplôme du Cours Specializaçào em Ciencias Documentais

09 Diplôme universitaire de Licenciatura ou de son équivalent (cursus universitaire de 4 ans) et épreuve de sélection.

12 L'objectif est de former des archivistes professionnels appelés à travailler dans le secteur public ou dans le secteur privé.

14 Sujets généraux: Histoire (30h); Droit et économie (2h), Science de l'Information (120h), Bibliothéconomie (120h), Latin (60h), Sociologie de l'information (30h), Informatique (50h).

15 L'expérience se déroule au long du cours avec des travaux pratiques faits pour plusieurs disciplines.

16 Diplôme délivré à l'issue de la scolarité complète, un contrôle continu ou un examen final, un travail de recherche et des exercices pratiques ou études de cas.

172 ans

ACADEMIC SUBJECT: COUNTRY: CITY, INSTITUTION:

\author{
Documentation \\ (5) Portugal \\ Lisboa, Universidade de Lisboa (p. 64)
}

07 Certificat de Spécialisation en Sciences Documentaires / Curso de Especialização em Ciencias Documentais

09 Diplôme Universitaire de Licenciatura

12 L'objectif est de former des archivistes professionnels appelés à travailler dans le secteur public ou dans le secteur privé, de former des gestionnaires de documents et du personnel de conservation.

14 Sujets généraux: Histoire (40h), Sciences de l'Information (70h), Bibliothéconomie (150h), Gestion (60h)

16 Diplôme délivré à l'issue de la scolarité complète, un contrôle contenu ou un examen final, un travail de recherche et des exercices pratiques ou études de cas.

$17 \quad 2$ ans 


\section{ACADEMIC SUBJECT: Health Informatics \\ COUNTRY: \\ CITY, INSTITUTION:

07 Bachelor of Science (BSc) in Health Informatics

08 1st level; full-time

12 The Health Informatics BSc course at City University offers broad yet focused study in this vitally important area with an exciting interdisciplinary mix for students interested in medical and health care subjects as well as computing and the management of information.

14 Core modules: Logic and Language of the Health Care; Health Care provision and systems; Medical Informatics; Introduction to Sets and Logic; Data and Knowledge Representation; Systems and Modelling Concepts; Introduction to Computer Systems; Introduction to Software Engineering; Introduction to Databases; Data Networking; Introduction to Business Systems; Business Systems Analysis; Business Decision Making; Information Communities and Users. Optional modules will be offered in a variety of specialised health informatics topics.

173 years

$\begin{array}{ll}\text { ACADEMIC SUBJECT: } & \text { Information Analysis } \\ \text { COUNTRY: } & \text { United Kingdom } \\ \text { CITY, INSTITUTION: } & \text { Aberdeen, Robert Gordon University (p. 80) }\end{array}$

07 Postgraduate Diploma, Master of Science (MSc) in Information Analysis

08 2nd level; full-time

09 A degree of a University of the United Kingdom or a degree of the Council for National Academic Awards or a degree from an Overseas University, or degree equivalent qualifications, subject to the approval of this Institute.

11 Application forms are available from and should be returned to the Admissions Office, RGU, Schoolhill, Aberdeen, AB9 1FR (Tel: +44(0)224-63.36.11)

12 The aim of the course is to prepare students to work as Researchers and Information Analysists: that is to be able to locate, bring together and analyse information from all relevant sources; to manipulate the information to extract its significance; to be able to present the information in a useful manner; and to provide information which is based on a clear understanding of the organizational context in which it will be used, both strategically and operationally. 
13 The diploma stage of the course is full-time for three terms. Students who successfully complete this part of the course and who do not wish to proceed a Masters degree will be awarded the postgraduate Diploma. Students who proceed to the Masters degree will continue on a part-time basis for 4 months whilst preparing their dissertation. In the first part of the course, studies are arranged so that staff/student contact time is concentrated in the first term to afford the student time to complete project work and also prepare for written examinations. The timetable allows for a flexible pattern of smallgroup teaching, lectures, individual tutorials and pratical work.

14 Business Policy, Planning and Decision Making, Publicy, Policy and Management, Financial Analysis and Decision Making in Business, Information Studies, Information Consolidation, Technical Communication, Information Technology, Research Methods

171 to 2 years

18 A wide variety of libraries and information centres, and positions outwith information world.

! UK \& EC domiciled self-financing: $£ 666$ pa. b) UK \& EC domiciled sponsored students, e.g., SOED, Employer: $£ 2650$ p.a. CNAA Registration Fee: $£ 25$

ACADEMIC SUBJECT:

COUNTRY:

CITY, INSTITION:

\author{
Information and Communication \\ France \\ Lyon, Université Jean Moulin-Lyon III (p. 18)
}

07 Licence, Maîtrise d'Information et Communication

08 2ème cycle; temps plein

09 Licence: réussir un test d'admission; sinon sur dossier; test de français si diplômés non francophones

10 Juin

11 Début mois d'octobre.

12 Former, à l'issue de deux années d'études et de stages, des généralistes de l'Information et de la Communication. Les options offertes en Maîtrise n'ont pas pour objet de préparer les étudiants à des métiers particuliers. Leur finalité est de former des cadres capables d'appréhender, de comprendre et de maîtriser les problèmes d'information et de communication interne ou externe qui se posent au sein d'une organisation (entreprise ou toute autre institution), puis de concevoir et de mettre en oeuvre une politique de communication globale et/ou de transfert d'information.

14 Licence: Théories et Pratiques de la Communication; Connaissance du Monde Contemporain sous ses divers aspects: Economiques, Politiques, Sociaux; Technique d'expression 
en usage dans les relations professionnelles (expression écrite, expression orale, bureautique, langue étrangère); Techniques de Recherche d'Information, à la base de tout métier de l'Information et de la Communication.

Maîtrise: Tronc commun (220 heures/étudiant): Aspects théoriques, Droit de l'information, Economie de l'information, Expression audio-visuelle, Publication assistée par ordinateur, Langue vivante: Option 1: Journalisme (190 heures/étudiant); Option 2: Communication d'entreprise

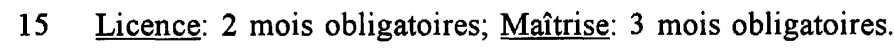

16 Le diplôme est attribué à l'étudiant s'il a obtenu une moyenne au moins égale à 10/20 pour chacune des unités de valeurs (contrôle continu et examen terminal) et le stage.

171 an pour chaque diplôme.

18 Métiers de l'information et de la communication d'entreprise, administrative, des collectivités locales.

ACADEMIC SUBJECT:

Information and Communication

COUNTRY:

CITY, INSTITION:

\author{
France \\ Lyon, Université Jean Moulin-Lyon III (p. 18)
}

07 DEA (Diplôme d'Etudes Approfondies) en Sciences de l'Information et de la Communication en association avec l'Université Lumière Lyon II et l'Ecole Nationale Supérieure des Sciences de l'Information et des Bibliothèques. ou DESS (Diplôme d'Etudes Supérieures Spécialisés)

08 3ème cycle; temps plein

09 Dossier de candidature.

10 Fin juin et mi-septembre.

11 Début du mois d'octobre.

12 Le but du DEA est l'apprentissage de la recherche: fondements épistémologiques, choix méthodologiques, construction d'une problématique, acquisition des instruments de la recherche. Le DEA constitue donc le début de la formation doctorale qui conduit à la préparation d'une thèse en 3 ou 4 ans.

DESS: Cette formation a pour but de préparer des cadres supérieurs aux métiers de l'information et la communication, notamment dans les domaines de la communication et de la documentation des entreprises et des organismes publics. Elle appartient à la catégorie des "DESS-double compétence": elle doit donc permettre à des étudiants ayant une formation supérieure dans un autre domaine d'acquérir une seconde compétence en Information et Communication. 
13 DEA: La formation comporte deux ensembles: un tronc commun, centré sur l'épistémologie et la méthodologie de la recherche, et cinq options qui permettent l'ancrage de la discipline dans un domaine particulier.

DESS: Modules théoriques; Modules méthodologiques; Langue étrangère (Anglais); Etudes de cas.

14 Tronc commun: Epistémologie, Méthodologie, Enseignement pratique: Option 1: Langages et symboliques de la communication et des médias. Option 2: Communication, organisation, représentation des connaissances. Option 3: Systèmes d'information documentaire. Option 4: Evolution et conservation des supports d'information. Option 5: Economie et management des services d'information

15 DEA: Des stages sont prevus. DESS: 4 mois obligatoires

16 DEA: Préparer un mémoire dans le cadre d'une des options, deux épreuves d'épistémologie, deux épreuves dans le cadre de l'option.

DESS: Pour être diplômé, chaque candidat doit obtenir une note moyenne au moins égale à $10 / 20$ pour l'enseignement théorique, les études de cas et le mémoire de stage.

1720 sémaines + stages en entreprise

18 Recherche et enseignement

ACADEMIC SUBJECT: COUNTRY:

CITY, INSTITUTION:
Information and Communication

United Kingdom

London, University of North London, Faculty... (p. 89)

07 Bachelor of Science (BSc (Hons)) in Applied Social Sciences (Information and Communication); Certificate in Higher Education (Successful completion of the Preliminary Level); Diploma in Higher Education (Successful completion of the Intermediate Level); Bachelor of Science (BSc (Hons)) Applied Social Science (Successful completion of the Final Level)

08 1st level; full-time

09 The sort of evidence that we are looking for includes: a) general awareness of current social/political/economic/ethical issues through reading of quality newspapers, relevant journals (eg. New Stateman and Society), popular social science paperbacks; b) relevant voluntary activity or paid work (prior practical experience of social work in either a paid or unpaid capacity is a compulsory requirement for admission to Social Work pathway); c) possession of the appropriate level of academic skills and aptitudes required to cope with first year undergraduate work, e.g., 5 GCE subjects with 2 at A-level; professional or academic qualifications equivalent to the above; The overall criterion for admission to the scheme is that students must be able to benefit from the study involved and be likely to succeed in obtaining the award for which they aim. 
11 Mid september normally-mid february in special circumstances.

12 This innovative scheme adopts interdisciplinary approach to the public issues in contemporary British society. The course enables traditional subject boundaries to be redrawn and contributes in new way to areas of study defined by both the issues and problems of Britain in the late 20th century and by the employment opportunities for social science graduates. Five main "pathways" through the scheme are offered: Health Studies, Information and Communication, Policy Studies, Social Research, Social Work. The name of the chosen pathway will be reflected in the final award.

13 The basic building block of the course is the unit of study. All units are of equal length 15 weeks or one semester. There are two semesters in the acedemic year, separated by one week, such that: Semester A runs from September/October to mid-February, Semester B rund from mid-February to June/July. All students normally take 24 units to complete the Honours degree programme, 20 units to complete the Degree programme, 116 units to complete the diploma programme, and 8 to complete the certificate programme. Units are designed by Level: Preliminary, Intermediate and Final. When you join the course, you will take a set of common foundation units: The pathway "Information and Communication" is designed to development both theoretical insights and practical competence in three broad inter-related fields: Information Technology, Librarianship and Mass Communication.

The specific aims of the pathway are as follows: a) to promote an appreciation of the contribution of the social sciences to understanding the role of information and communication systems in the contemporary world; b) to examine the technical, economic, legal, political and social contexts of the production, distribution and consumption of information; c) to analyse the growth and development of the Information and Communications Industry and its related professions; to equip students with the technical skills for understanding, programming, handling and analysing data appropriate to the latest development in Information Systems; d) to enable students with a vocational commitment to Library and Information services to undertake studies to professional recognition as Librarians, Information Scientists and Communication Specialists.

14 Individual in Society I, Social History and Social Policy, Introduction to Law, Information Skills, these units represent the basic requirements for all five pathways and also act as "tasters" for subjects where students have little or no previous experience. This will help you to decide on your subsequent choice of programme.

You then choose four option units from the following nine offered at this Level: Economy and Society, Individual and Society II, Information Needs Analysis, Introduction to the Administration of Justice, Political Institutions \& Processes, Political Philosophy \& State Intervention, Social Structure \& Social Process, Social Thought \& Social Change, Information and Society, or up to two options from courses elsewhere in the University. You may defer your final choice of pathway until the end of the Preliminary Level: Information and Communication: intermediate Level: Fundamentals of Automated Information Processing, Computers and Information Access, Cultures, Information and Communication, Political and Economic Analysis of Information and Communication Systems, final Level: Principles and Practice in Information and Communication Work, Information and Communication Project, New Directions in Communication and Information, Consultancy and Research in Information and Communication work. 
15 Practical studies are intended; practical studies can be carried out by various worker projects, group work, practical placements, computer-based-projects; we have exchange agreements with same institutions and are exploring links with more in Europe and the USA.

164 exams and end of first semester at Preliminary Level. Therafter a mixture of exams and coursework assessment according to modulars chosen.

17 Preliminary Level: 2 Semesters of 15 week each. Intermediate and Final Level: both of 15 weeks each of two semesters, growing a totalite of 6 semesters over 3 years. The Degree is modular requiring students to take 4 modules each semester, 8 per year, and 24 over the three years. Results for taken in the first year do not came towards the degree classification.

18 The design of information systems and the provision of information services in a wide variety of institutions and environments - e.g., commerce, industry, National Health Service (NHS) and other care agencies, central and local government, trade unions, voluntary agencies; public, academic and specialist libraries, information management in financial services, research and development organisations, and knowledge-based industries; specialist information and communication roles in publishing, journalism, and broadcasting, the media and recording industries; public relations, promotional activities, community information services, information consultancies.

ACADEMIC SUBJECT:

COUNTRY:

CITY, INSTITUTION:

\author{
Information and Computer Science \\ Sweden \\ Lund, Lunds Universitet, Informationsbehandling - \\ ADB (p. 77)
}

07 Bachelor of Science (BSc), Master of Social Science (MSSc); Doctor of Philosophy $(\mathrm{PhD})$ in Information and Computer Science

08 1st and 3rd level; full-time

09 A complete upper secondary education such as High School, Abitur, Baccalaureate, CGE-O/A levels, etc. A good command of the Swedisch language; A good command of English; A good knowledge of Mathematics and Civics.

11 December first, deadline for submitting applications for studies to the Swedish Embassy/Consulate in your home country; April 15th, deadline for English proficiency test results; January-May, evaluation for each applicant's qualifications; March-April, after beeing notified by UHÄ (Universitets- och Högskoleämbetet = National Swedisch Board of Universities and Colleges), the Swedish local Embassy/Consulate will call each eligible applicant for an interview concerning the residence permit. If you have been found not eligible, you will be notified directly by UHÄ; May-June, if admitted, you will receive a letter of acceptance from UHÄ.

12 To get a good knowledge of Systems Design. 
14 Information and Computer Science, General Course I, II + III , Data Communication, Decision Support Systems, Designing for Communications and Cooperation, Design Science, Human Computer Interaction, Information and Computer Security, Introduction to Knowledge-based Systems, Knowledge-based Systems in Administrative Systems; advanced courses: Strategical Evaluations of Information Systems, Systems Theory, Information and Computer Science I, II + III, Degree project

15 Practical studies are not intended.

16 Exams after each course

173 years for a Bachelor of Soc. Sciences

18 Programmer, System Designer

! Before you will be granted a residence permit, the Swedish Immigration board will request you to prove that you will have enough money to cover your expenses during your entire stay in Sweden. At present (spring 91) a sum of 4700 SEK per month, for at least 10 months of year is required. Studies at universities and university colleges are free of charge.

ACADEMIC SUBJECT: COUNTRY:

CITY, INSTITUTION:

\author{
Information and Computing Studies \\ United Kingdom \\ Loughborough, Loughborough University of Tech- \\ nology (p. 90)
}

07 Bachelor of Science (BSc (Honours)) in Information and Computing Studies

08 1st level; full-time, part-time

09 The GCSE or O-level passes at grade $\mathrm{C}$ or above must normally include Mathematics or a science subject, and a modern language. If you are applying straight from school, you usually need to obtain grades BC if taking two, or CCC if taking three A-levels. There are no specific A-level subject requirements for Information and Library Studies as such, but for certain of the minor subjects you will be expected to have appropriate A-level pass.

11 In October of each year.

12 This course is designed to meet the exploding demand for graduates across the whole range of communication industry. It offers an integrated approach to all forms of humancomputer interaction, with a special emphasis upon automated Information Handling and Information Management.

14 Computing, Application Environments, Information and Society, Information Management, Data Analysis and Presentation, Human Factors in Equipment Design, Information 
Systems, Human Computer Systems, Systems Analysis and Development, Information Management, Information Services, Human Information Processing

173 or 4 years

18 On completing the course students will be equipped to take up a first professional post in an information service or a library, or in any of the many organizations requiring a skilled information professional.

\author{
ACADEMIC SUBJECT: Information and Documentation \\ COUNTRY: \\ Belgium \\ CITY, INSTITUTION: Bruxelles, Université Libre de Bruxelles (p. 4)
}

07 Licence spéciale en Sciences de l'Information et de la Documentation; Doctorat en Philosophie et Lettres

08 2ème et 3 ème cycle; temps plein

09 Les systèmes d'information sont susceptibles de couvrir l'éventail complet des disciplines scientifiques. Il n'est évidemment pas concevable de donner aux spécialistes de l'information un enseignement encyclopédique qui s'étendrait à toutes les branches du savoir. La connaissance des matières traitées dans les systèmes d'information doit donc être acquise ailleurs. $C^{\prime}$ est la raison pour laquelle l'accès aux cours de la section n'est ouvert que a) aux porteurs d'un diplôme de deuxième cycle d'une Université belge ou d'un diplôme jugé équivalent par le jury; b) aux porteurs d'un diplôme de l'enseignement supérieur non universitaire belge ayant rempli une fonction de responsabilité dans une bibliothèque ou un service de documentation pendant une période continue de trois ans au moins; c) à titre exceptionnel, aux porteurs d'un diplôme de l'enseignement moyen (cycle supérieur) belge, ayant rempli une fonction de responsabilité dans une bibliothèque ou un service documentation pendant une période continue de cinq ans au moins.

10 Tous le candidats devront introduire, avant le 31 août, une demande d'admission, accompagnée d'un dossier auprès du Bureau des Equivalences, Université Libre de Bruxelles, C.P. 176, Avenue F.D. Roosvelt 50, B-1050 Bruxelles.

11 L'année académique se déroule du 25.9 au 30.6.

12 La section INFODOC a pour vocation d'apporter aux praticiens et futurs praticiens de bibliothèques et centres de documentation ainsi qu'aux concepteurs des systèmes $\mathrm{d}^{\prime}$ information les connaissances leur permettant de maîtriser la diversité croissante des flux d'informations, de s'adapter aux besoins fluctuant des utilisateurs et de dominer une technologie en pleine évolution.

13 Les cours sont conçus pour permettre l'accès des personnes déjà engagées dans la vie professionelle. 
14 lère année: Système d'information; Psychosociologie du traitement de l'information; Indroduction à l'Informatique; Algorithmique et programmation; Télématique; Méthodes d'analyse statistique; Langages de représentation des connaissances; Introduction à la bibliothéconomie; Introduction à la documentologie; Système d'information d'entreprise; 2ème annee: Management des systèmes d'information; Systèmes de gestion de la connaissance I + II; Travaux pratiques de micro-informatique; Banques d'information; un cours optionnel à choisir parmi: Automatisation de bibliothèques; Automatique documentaire; Représentation et traitement des connaissances; Traitement automatique de langages naturels.

15 Les stages ne sont pas prévus dans le programme. Toutefois, à la demande des étudiants, dans des cas particuliers, il est possible d'envisager de telles activités.

16 Tous les cours doivent faire l'objet d'un examen sauf si une dispense résultant de la formation antérieure a pu être accordée.

$17 \quad 2$ ans

ACADEMIC SUBJECT: COUNTRY: CITY, INSTITUTION:

\author{
Information and Documentation \\ France \\ Lyon, Université Jean-Moulin-Lyon III (p. 18)
}

07 Diplôme d'Etudes Universitaires Scientifiques et Techniques (DEUST), Diplôme d'Etudes Universitaires Générales (DEUG) en Information-Documentation

08 ler cycle; temps plein

12 Les entreprises recherchent un personnel ayant à la fois une bonne culture générale, qui est donnée par un premier cycle d'enseignement supérieur, et une solide formation technique, assurée par des professionnels et complétée par un stage en entreprise. On a noté auprès de petites et moyennes entreprises et des établissements de l'artisanat le besoin d'un service commun de secrétariat capable d'assurer ausssi les services de documentation, d'archivage et de traitement de informations.

14 Premiere annee: DEUG: Histoire; Géographie; Lettres Modernes. DEUST: Dactylographie; Rédaction; Anglais; Gestion et comptabilité; Micro-économie; Connaissance de l'entreprise; Communication de l'entreprise. Cours de culture générale du tronc commun. Deuxieme anne: L'étudiant doit donc subir trois types d'épreuves: matières de dominante d'un DEUG; matières spécifiques du DEUST et une option (entreprise; bibliothèque; doc. adminsitrative).

15 Un stage de deux mois.

16 L'assiduité est obligatoire et contrôlé.

$17 \quad 2$ ans 
ACADEMIC SUBJECT: COUNTRY:

CITY, INSTITUTION:
Information and Documentation

France

Los Lyon, Université Jean-Moulin-Lyon III (p. 18)

07 Module d'Information-Documentation associé à une Licence.

08 2ème cycle; temps plein

09 Procédure habituelle d'inscription en Licence.

12 Ce module est un enseignement d'initiation à la recherche, à la gestion et au traitement de l'information.

14 Recherche et techniques documentaires; Informatique documentaire; Techniques de communication; Fonction et gestion d'un service d'information; Economie de l'information.

16 Le contrôle des aptitudes et connaissances se fera sous la forme de cinq devoirs écrits en temps limité.

171 an

! La Maitrise des Sciences de l'Information et de la Documentation, la préparation au CAPES de Documentation, constituent des suites possibles, et naturelles, aux licences assorties de ce module.

\section{ACADEMIC SUBJECT \\ COUNTRY: \\ CITY, INSTITUTION:}

\author{
Information and Documentation \\ France \\ Paris, Institut d'Etudes Politiques de Paris (IEP) (p.23)
}

07 Diplôme d'Etudes Supérieures Spécialisées (DESS) en Information et Documentation

083 ème cycle; temps plein

09 Niveau de diplôme exigé: Maîtrise $(B A C+4)$ en Sciences sociales ou humaines ou titulaire d'un diplôme d'Institut d'Etudes Politiques ou d'une école de commerce. Nombre d'étudiants limité à 20 (pas d'adultes ayant déja une expérience professionnelle).

10 Dates d'inscriptions: du ler Juin au 13 Juillet; retour du dossier: 24 Juillet au plus tard.

111 an: de mi-octobre (rentrée et stages) à mi-octobre (soutenance du mémoire).

12 Le DESS a pour finalité de former des spécialistes capables de concevoir et de gérer des systèmes et/ou des services d'information dans des secteurs d'activité extrêment diver- 
sifiés (administrations, organismes para-publics, banques, entreprises et sociétés de services).

13 Au moins 500 heures de cours théoriques et pratiques, travaux personnels, visites, quatre mois de stages.

14 Introduction Générale; 1. Informatique Générale et Informatique Documentaire; 2. Analyse et Traitement de l'Information; 3. Recherche de l'Information; 4. Organisation et Gestion de l'Information; 5. L'Entreprise: son Information et son Environnement; 6: Mathematiques et Statistiques; 7. Bureautique et Télématique; 8. Droit de l'Information; 9. Audiovisuel; 10. Anglais

154 mois de stages (parfois 6 mois); 3 types de stages: 2 stages d'initiation d'une semaine chacun (micro-informatique et introduction au monde professionnel; 1 stage de formation aux logiciels documentaires ( 3 semaines); 1 stage d'application (de 3 à 6 mois) avec rédaction d'un mémoire. Les stages peuvent se dérouler à Paris, en province ou à l'étranger.

16 Examens passés de manière continue (travaux sur table / en groupe) pendant la scolarité.

171 an à temps plein.

18 Documentalistes chargés d'études documentaires; Responsables de services d'information; Consultants en systèmes d'information; Ingénieurs linguistes pour l'information et la documentation.

\begin{tabular}{lll} 
ACADEMIC SUBJECT: & \multicolumn{2}{l}{ Information and Documentation } \\
COUNTRY: & Germany \\
CITY, INSTITUTION: & Darmstadt, Fachhochschule Darmstadt (p. 35)
\end{tabular}

07 Diplominformationswirt in Information und Dokumentation

08 1. Ebene; Vollzeitstudium; der Fachbereich Information und Dokumentation der FH Darmstadt bietet im Studiengang Information und Dokumentation zwei Fachrichtungen an: 1. Medien- und Wirtschaftsinformation und 2. Chemieinformation.

09 Allgemeine Hochschulreife oder Fachgebundene Hochschulreife; Studienbewerber mit DDR-Zeugnissen oder aus den neuen Bundesländern müssen diese beim Hessischen Ministerium für Wissenschaft und Kunst, Luisenplatz 10, D-65185 Wiesbaden, Tel: $+49(0) 611-16.50$, anerkennen lassen; Studienbewerber mit ausländischem Bildungsnachweis müssen ihre Hochschulzugangsberechtigung durch das Studienkolleg für ausländische Studierende, Wiesenstr. 14, D-35390 Giessen, Tel: +49(0)64.11-30.92.50, bewerten lassen. Ausreichende deutsche Sprachkenntnisse sind bei der Bewerbung nachzuweisen. EG-Bürger mit ausländischem Bildungsnachweis werden zulassungsrechtlich wie deutsche Studienbewerber behandelt. Trotzdem ist es erforderlich, die Zeugnisse in Giessen bewerten zu lassen sowie deutsche Sprachkenntnisse nachzuweisen. 
11 Ein Studienbeginn ist nur im Wintersemester möglich. Die Bewerbung muß bis spätestens 15. Juli (Ausschlußfrist) an die FH Darmstadt gerichtet sein.

12 "Informationsspezialisten" moderner Ausprägung werden nur dann qualitativ gute Informationen leisten können, wenn sie in den drei wichtigen Aspekten der Informationsarbeit eine auf wissenschaftlicher Basis fundierte berufs- und praxisbezogene Ausbildung vermittelt bekommen: Informationstechnik (Anwendung moderner Techniken für die Zwecke der Informationsvermittlung), Informationsmethodik (Methoden und Verfahren der Erfassung, Erschließung und Vermittlung der Information), Fachanteil (Kenntnis über die wichtigen Zusammenhänge in dem Fach, über das informiert werden soll). Hierzu werden die beiden Fachgebiete Medien- und Wirtschaftsinformation und Chemieinformation angeboten.

13 Das Studium gliedert sich in ein Grundstudium von 2 Semestern und ein Hauptstudium von 4 Semestern zuzüglich eines berufspraktischen Studiensemesters. Im 8 . Semester wird der 2. und 3. Teil der Diplomprüfung abgelegt (Prüfungssemester).

14 Das zweisemestrige gemeinsame Grundstudium vermittelt Grundlagen der Informationstechnik und Informationsmethodik: Informationsmethodik I+II, Datenstrukturierung I+II, Praxis der Informationssysteme, Information Management I+II, Struktur des IuD-Wesens I+II, Technik der Informationssysteme I+II, Informationswissenschaft I, Medien- und Wirtschaftsinformation I+II, Massenkommunikation I, Englisch I, Wahlpflichtfach "Sozial- und Kulturwissenschaften", Chemie-Information I+II. Im Hauptstudium der Fachrichtung "Medien- und Wirtschaftsinformation" werden die Fachanteile Massenkommunikation, Wirtschaftswissenschaften und Statistik neben den informationsbezogenen Lehrinhalten vermittelt: Informationsmethodik III+IV, Datenstrukturierung III+IV, Praxis der Informationssysteme III+IV, Informationsmanagement III+IV, Praktikumsbegleitendes Kolloquium, Technik der Informationssysteme III+IV, Informationswissenschaft II-IV, Medien- und Wirtschaftsinformation III+IV, Massenkommunikation II-IV, Wirtschaftswissenschaften I-IV, Englisch II, Projektarbeit I+II, Wahlpflichtfächer Information und Dokumentation, Wahlpflichtfächer Sozial- und Kulturwissenschaften, Vorbereitung auf die Diplomarbeit, Statistik I+II. Im Hauptstudium der Fachrichtung "Chemieinformation" werden in sehr hohem Maße die chemischen Fachanteile vermittelt, die durch das Fach Chemie-Information auf die Informationsarbeit hin ergänzt werden. Mathematik, Physik I+II, Labor- und Sicherheitstechnik, Allgemeine Chemie, Anorganische u. Analytische Chemie I+II, Anorganisches und Analytisches Praktikum, Organische Chemie I+II, Org. Chemisches Praktikum, Physikalische Chemie, Technische Chemie I+II, Verfahrenstechnisches Praktikum, Wahlpflichtfächer Chemie, Wahlpflichtfächer IuD, Wahlpflichtfächer Sozial- und Kulturwissenschaften, Chemieinformation III+IV, Informationsmethodik III, Informationsmanagement III, Informationswissenschaft II, Technik der Informationssysteme III, Projektarbeit, Vorbereitung auf die Diplomarbeit, Praktikumbegleitendes Kolloquium.

15 Nach dem Grundstudium ist ein berufspraktisches Studiensemester abzuleisten.

16 Die Diplomprüfung ist am Ende des 8. Semesters abzulegen

178 Semester 
18 Die Tätigkeitsfelder der Diplominformationswirte sind: Informationsvermittlungs- und Beratungsstellen, Informations- und Dokumentationsstellen der Forschung und Entwicklung (z. B. Patentabteilungen), der Bereich der innerbetrieblichen Information und Dokumentation, der Bereich der Entwicklung von Informationssystemen, der Bereich der Beratung und Schulung bei Datenbankanbietern und Hosts, Informationsvermittlungsstellen der Presse, des Rundfunks, Unternehmen und der Verbände der Wirtschaft.

! Ca. 70\% der Studierenden sind weiblichen Geschlechts; extrem hoher Anteil an LaborÜbungen (Praxis-Bezug).

ACADEMIC SUBJECT: COUNTRY: CITY, INSTITUTION:
Information and Documentation

\section{CS Germany}

Potsdam, Institut für Information und Dokumentation(IID) (p. 43)

07 Wissenschaftlicher Dokumentar in Information und Documentation

08 3. Ebene; Vollzeitstudium; berufsbegleitende Ausbildung zum Wissenschaftlichen Dokumentar

09 Abgeschlossenes Hochschulstudium, $1 \mathrm{Jahr}$ Berufstätigkeit in einer IuD-Einrichtung. Im Jahr der fachtheoretischen Ausbildung muß der Student in einer einschlägigen Praxisinstitution berufstätig sein. Englische Sprachkenntnisse sind nachzuweisen.

10 Bewerbungsschluß ist der 1. Oktober eines jeden Jahres.

11 Jeweils zu Beginn des Jahres.

12 Beschäftigte in den Praxisbereichen des Informationswesens sollen eine wissenschaftlich fundierte und praxisbezogene Qualifikation erwerben, die ihre beruflichen Chancen erhöht. Dazu gehören: 1. Vermittlung informationswissenschaftlicher Ansätze und Verfahren, 2. Vermittlung informationsmethodischer Kenntnisse und Fähigkeiten, 3. Vermittlung informations- und kommunikationstechnologischer Kenntnisse und Fähigkeiten, 4. Förderung der Fähigkeit, einzelne Verfahren und Methoden in übergeordnete Zusammenhänge einordnen zu können, 5. Förderung der Fähigkeit, durch geeignete Arbeitsund Planungsmethoden informationelle Systeme und Prozesse gestalten zu können.

1313 anwesenheitsbezogene theoretische Ausbildungswochen innerhalb eines Jahres.

14 Informationswesen, Entwurf von Informationssystemen, InhaltlicheErschließung/Wissensrepräsentation, Information Retrieval, Informationmanagement

15 Praktika sind nicht vorgesehen.

165 Leistungsnachweise, Abschlußprüfung bestehend aus schriftlicher Abschlußarbeit und mündlicher Prüfung. 
$171 \mathrm{Jahr}$ mit 13 anwesenheitsbezogenen Ausbildungswochen

18 Dokumentar, Informationsvermittler

! Die Studiengebühren betragen 5000 DM plus 500 DM Prüfungsgebühr.

ACADEMIC SUBJECT: Information and Documentation

COUNTRY:

Spain

CITY, INSTITUTION: Madrid, Centro de Información y Documentación

Científica (CINDOC) (p. 71)

07 Certificado de Aistencia en Información y Documentación para Titulados y Documentalistas

09 Derechos de matrícula. Plazas limitadas.

11 Según el programa de cursos.

12 Formación de científicos documentalistas.

14 Formación de usuarios de los servicios de Información y Documentación, fuentes de Información en ciencias humanas; Aproximación teórico práctica a los lenguajes documentales, Introducción a los tesauros; Recursos de Información en ciencias sociales; Introducción a la terminología científica; Análisis documental; Introducción a las busquedas retrospectivas en linea; Fuentes y recursos de Información en ciencias historicas; Formación de usuarios de Información y Documentación científica y técnica; Creación de bases de datos

15 Realización de supuestos.

16 Ninguno.

17 Una semana.

18 Científicos documentalistas

$\begin{array}{ll}\text { ACADEMIC SUBJECT: } & \text { Information and Library Management } \\ \text { COUNTRY: } & \text { United Kingdom } \\ \text { CITY, INSTITUTION: } & \text { Manchester, Manchester Metropolitan University (p. 91) }\end{array}$

07 Bachelor of Arts (Honours) in Information and Library Management

08 1st level; full-time or part-time 
09 Normal Entry: Applications for admission to the start of the course will be considered on the basis of standard academic criteria (e.g., 2 A-level passes plus 3 O-level/GSCSE passes, including English and Mathematics) or equivalent qualifications. Applicants with "mature status" (over 21) will be considered on the basis of their work experience and potential ability to complete the course successfully.

Admission with Advanced Standing: Admission with Advanced Standing is available to applicants with a suitable mix of academic qualifications and/or relevant work experience. Such applicants will be considered for direct entry to the second year of the full-time course, or its part-time equivalent. Such applicants may be required to undergo a oneweek learning/assessment programme for which a fee will be charged.

11 In September; Applications for entry to the First Year of the full-time mode should be made through PCAS, PO Box 67, Cheltenham, UK-Gloucestershire GL50 3SF.

12 This stimulating and challenging Honours degree course offers an opportunity to develop the skills necessary for Information and Library Managers in meeting the information and communication needs of modern society. The effective control and management of information is necessary in all organizations, including libraries of various types and sizes, educational establishments, central government, and business and commercial organizations. Many of the skills and the knowledge that the information professionals needs are common to a wide variety of work environments. For example, one of the core topics covered on the course is Information Access, which is the identification, organisation and retrieval of information. This is equally important to the librarian in public and academic libraries, and to the business manager who requires accurate and up to date information for effective decision-making.

13 The aim of the course is to develop your intellectual, social, and personal abilities, but especially, at the conclusion of the course you will have acquired the following skills and knowledge: an understanding of the needs of information users; the ability to organise information for retrieval; the ability to locate information in electronic and printed sources; an appreciation of the role of management; an understanding of the role of information professional in organisation and society. In addition you will have gained experience of working independently and as part of a group; the use of information technology, numerical and expressive skills; the analysis and synthesis of information, and the identification of problems, together with the development of solutions.

14 Information Access, Management of Library and Information Systems, User Communities/elective studies, Information Technology, Library and Information Environment/Information and Society, Communication Skills, Research Methods, Information Management.

15 Students undertake two periods of 5 week work placement, in organizations that are relevant to their study and specific interests in year 1 and year 3 of the course.

16 Exams in all subjects in end of year 1; assessed course works in year 1-3; final exams in year 3; 50/50 exams/assessed

173 years 
18 Libraries, public, special, academic; Information Management Research; Computer System Management

! Entrance without fee.

ACADEMIC SUBJECT:

COUNTRY:

CITY, INSTITUTION:

\section{Information and Library Management}

United Kingdom

Newcastle upon Tyne, University of Northumbria at Newcastle (p. 92)

07 Bachelor of Arts (BA), University Diploma; Master of Arts (MA)/Master of Science (Taught courses); Master of Philosophy (MPhil); Doctor of Philosophy (PhD by research) in Information and Library Management

08 1st, 2nd or 3rd level; full-time, part-time

09 For BA: two Advanced Level subjects or equivalent; for Master: first degree at recognised institution in any subject.

Number of students they can start studies each term: BA: 50 full-time, 12 part-time; Diploma: 48 full-time, 10 part-time; MA-MSc: 10 full-time (part-time route also avaiable).

10 The deadline for enrolment is the first day of course. Applications should be submitted as soon as possible in previous academic year.

11 The studies start September annually.

12 To prepare graduates for employment, particulary in information and library environments.

13 Currently 3 term year; moving to $2 \times 15$ week semesters in 1994 . Average 15 hours per week; $50 \%$ lecture and $50 \%$ practical/seminars.

15 Practical studies are compulsory. Practical studies can be carried out: BA: 3 weeks at end of year $1 ; 4$ weeks at start of year 3; possibilities to have practical studies in foreign countries.

16 BA course: $2 \times 3$ hour exams at end years $1 \& 2 ; 1 \times 3$ hour exams at end year 3 . Diploma courses: no exams. All have continuous assessment of course work.

17 BA full-time: 3 years (9 terms); BA part-time: 5-7 years; Diploma full-time: 10 months; Diploma part-time 2 years (20 months); MA/MSc full-time: 14 weeks; MA/MSc parttime: $15-36$ months.

18 Information officers and Librarians in wide range of institutions. IT related posts in business and industry. 
$1 \quad$ Unitisation across institutions to allow wider choice of options. Diploma Information and Records Management to be offerd from September 1992. BSc Communication analysis with Languages and Information Technology from September 1994.

\section{ACADEMIC SUBJECT: COUNTRY:} CITY, INSTITUTION:

\author{
Information and Library Science \\ United Kingdom \\ Birmingham, University of Central England (UCE) in \\ Birmingham (p. 82)
}

07 Bachelor of Arts (BA (Hons)), Postgraduate Diploma, Master of Arts (MA), Master of Science (MSc) in Librarianship and Information Studies

e8 1st or 2nd level; full-time, part-time

09 A-Level examination and subject to interview or attendance at open day.

10 No deadline for enrolment, but course may fill up.

11 September/October of each year.

12 a) To provide an education to honours degree level in Librarianship/Information Studies in which the academic and personal development of the student during the in-college course is integrated with the development of professional and personal competence during a supervised placement in a Library and Information Service. b) To promote the intellectual development of the students and to enhance their critical awareness through the study of a range of aspects of Library and Information Services and their value to the communities and users for whom they are provided. c) To enable students to study one of a range of specialized pathways within the information professions. d) To encourage the development of student's confidence and maturity through independent work, rading, discussion and creative problem solving in a supportive environment. e) To enable students to develop professional awareness an involvement within an approved Library and Information Service and to formulate career plans. f) To encourage the ability to evaluate and communicate data, information and ideas.

14 Core units Level 1: Communication and reseach methods 1; Information Resources; Information Retrieval 1; Information Society; Information Technology. Foundation Units Level 1: Business Information; Information Management; Libraries in Education; Public Librarianship. Core Units Level 2: Information Retrieval 2; Information Services; Management; Management Decision Making. Pathway Units Level 2: Business Information Sources; The Child and the Society; Human Aspects of Management; Records Management; Retrieval System Design. Pathway Units Level 3: Business Information or Information Management; Libraries in Education or Public Libraries. Other Units: Children's Literature; Information Design and Repacking; Local Studies; Popular Fiction

15 The undergraduate course contains 9 month full-time (paid) placement across year 2 and year 3 . 
16 The placement will be assessed on the basis of a) written theme paper and formal presentation, b) work record book and c) appraisal of professional competencies. The determination of the class of degree contained of the a) placement project, b) assessed work from 8 in-college pathway units, c) assessment of placement units and d) performance on pathway examinations.

173 years $(9$ terms)

18 Enormous variety: public libraries, school libraries, university libraries, government libraries, business information, health information, software suppliers, research

ACADEMIC SUBJECT:

\section{COUNTRY:}

CITY, INSTITUTION:

\author{
Information and Library Science \\ United Kingdom \\ Glasgow, University of Strathclyde (p. 85)
}

07 Master of Science (MSc), Postgraduate Diploma in Information and Library Studies

08 2nd level

09 Diploma / Master of Science; Honours Degree of Equivalent

11 September

12 To create graduates capable of working in a wide range of information careers in the public and private sectors.

14 Information Technology and Systems; Information Needs and Users; Publishing and the Distribution of Information; Information Sources and Resources; Management of Library \& Information Systems

15 Software applications packages for all courses for 3 weeks in library or information services.

16 Examination in all classes, taken in May/June.

18 Range of professional information posts in public and private sectors. 


\begin{tabular}{lll} 
ACADEMIC SUBJECT: & \multicolumn{2}{c}{ Information and Library Science } \\
COUNTRY: & United Kingdom \\
CITY, INSTITUTION: & Liverpool, Liverpool John Moores University (p. 86)
\end{tabular}

07 Bachelor of Arts (BA (Hons)), Bachelor of Science (BSc (Hons)), University Diploma, Master of Arts (MA), Master of Philosophie (MPhil), Doctor of Philosophy (PhD) in Information and Library Studies

08 1st, 2nd or 3rd level; full-time, part-time

09 BA (Hons), Bsc (Hons): You must be at least 18 years old und should normally hold one of the following qualifications: a) GSCE/GCE passes in five subjects of which one must be English Language und two must be at A/AS-level; b) GCSE/GCE passes in four subjects of which one must be English Language und three must be at A/AS-level; c) a good BTEC National Award or Ordinary National Certificate or Diploma; d) an equivalent qualification.

Mature students over 21 without basic qualifications will also be considered for direct entry. For all candidates a good reference is essential.

MA and PgD: The course is normally open to students holding degrees awarded either by UK universities or by the Council for National Academic awards (CNAA). Students from holding degrees from overseas universities or other equivalent qualifications may be admitted at the discretion of Board of Studies.

10 15th December of each year.

12 To provide information workers/librarians who are qualified to play a sophisticated role in our developing technological society.

13 Courses are taught on a modular/credit basis.

14 BA (Hons) and BSc (Hons): The course reflects a natural development from traditional Librarianship, with its emphasis on books, to present day Information Handling, with greater emphasis on the use of machine-readable sources. It also stresses the importance of people in information services.

$\mathrm{PgD}$ and MA: Information Needs and Services, Library and Information Services, Information Sources, Information Storage and Retrieval, Information Technology, Special Study.

15 Students go out on professional placements.

16 Students are assessed by a mixture of examinations and coursework for the BA/BSc and by coursework only for the Diploma and MA.

17 BA and BSc 3 years, PgD one year full time, MA one year part time.

18 Libraries, information services and other information related posts 
ACADEMIC SUBJECT:

COUNTRY:

CITY, INSTITUTION:

\author{
Information and Library Science \\ United Kingdom \\ Loughborough, Loughborough University of Techno- \\ logy (p. 90)
}

07 Bachelor of Arts (BA), in Bachelor of Science (BSc (Honours)) in Information and Library Studies

08 1st level; full-time

09 The GCSE or O-level passes at grade C or above must normally include Mathematics or a science subject, and a modern language. If you are applying straight from school, you usually need to obtain grades BC if taking two, or CCC if taking three A-levels. There are no specific A-level subject requirements for Information and Library Studies as such, but for certain of the minor subjects you will be expected to have appropriate A-level pass.

11 In October of each year.

12 This course provides a balanced and critical study of all important aspects of library and information work.

13 During the first two years of the course, students study a foreign language and an minor subject chosen from: Economics, Social Science, English, Geography, Computing, Human Sciences, Historical Studies, Education. In the third or fourth year of the course, students take further courses in the management of information services and legal and professional issues together with three optional courses.

14 Information Handling, Information and Society, Management of Information Services, Applications of Information Technology, Data Collection and Analysis, optional courses: Publishing and Book Trade, Mass Media and Audio-visual Communication, Archive Administration, Records Management, Childhood and Childrens' Literature, Local Studies Librarianship, Health and Welfare Information Management, History of Communication, Preservation in Libraries and Archives, Human Factors in Information Systems Design, Business Information, International Librarianship and Information Work.

15 In order to extend students' professional knowledge and skills a period of six weeks' work experience is undertaken in the two long vacations.

16 Students undertake a project essay about 10.000 words (or the equivalent in software and a user manual and report).

173 or 4 years

18 On completing the course students will be equipped to take up a first professional post in an information service or a library, or in any of the many organizations requiring a skilled information professional. 


$\begin{array}{lll}\text { ACADEMIC SUBJECT: } & \text { Information and Library Science } \\ \text { COUNTRY: } & \text { United Kingdom } \\ \text { CITY, INSTITUTION: } & \begin{array}{l}\text { Loughborough, Loughborough University of } \\ \text { Technology (p. 90) }\end{array}\end{array}$

07 Master of Arts (MA) Master of Science (MSc), Diploma of Loughborough University of Technology (DLUT) in Information and Library Studies

08 2nd level; full-time, part-time

09 Applicants should have a good honours degree and about one year's experience (six week's minimum in exceptional circumstances), which can encompass a whole range of library or information-related jobs.

11 In October of each year

12 This programme aims to give students a broad professional education that will enable them to enter confidently into a range of library and information jobs. It provides a broad understanding of the principles of librarianship and information work, of the organisation of libraries and other information agencies, and of the handling, storage and retrieval of information in all media.

14 Information Management, Information Source, Use and Searching, Collections and Services, Information Handling, optional modules: Archive Administration, Business Information, Childhood and Children's Literature, Health and Welfare Information Management, Human Factors in Information Systems Design, International Librarianship and Information Work, Legal and Professional Issues, Mass Media and Audio-visual Communication, Preservation in Libraries and Archives, Publishing and Book Trade, Records Management.

16 Assessment for the MA or MSc degrees is by course-work and dissertation; for the DLUT by course-work and project report.

171 year full-time or 3 years part-time

$\begin{array}{ll}\text { ACADEMIC SUBJECT: } & \text { Information Management } \\ \text { COUNTRY: } & \text { Austria } \\ \text { CITY, INSTITUTION: } & \text { Wien, Wirtschaftsuniversität Wien (p. 2) }\end{array}$

07 Magister der Sozial- und Wirtschaftswissenschaften (Mag. rer. soc. oec), Doktor der Sozial- und Wirtschaftswissenschaften (Dr. re. soc. oec) in Spezieller Betriebswirtschaftslehre Informationswirtschaft im Rahmen der Studien Betriebswirtschaft, Handelswissenschaft und Wirtschaftspädagogik an der Wirtschaftsuniversität Wien 
08 2. Ebene; Vollzeitstudium

09 Der 1. Studienabschnitt an der WU sollte abgeschlossen bzw. weit fortgeschritten sein. Voraussetzung für die Wahl der Besonderen Betriebswirtschaftslehre Informationswirtschaft ist neben dem Interesse für Informationswirtschaftliche Fragestellungen die Bereitschaft zu selbständiger projektorientierter Arbeit.

11 Studienbeginn ist zu jedem Semesterbeginn möglich (WS = Oktober, SS = März). Zur Zeit ca. 30 Neuaufnahmen pro Semester.

12 Die Ausbildung konzentriert sich auf: a) Prozesse und Maßnahmen zur effizienten Nutzung von Information und zur Gestaltung effizienter Informationsverarbeitung, b) zeitlose Theoreme und Erkenntnisse im Informationsverarbeitungsbereich und c) die ökonomische Effekte von Information und Informationstechnik.

14 Grundlagenprogramm: Informationsmanagement in Organisationen I+II, Datenmanagement in Organisationen, Programmierarbeitsgemeinschaft. Es sind einer der drei folgenden Forschungsschwerpunkte zu wählen: Informationsbeschaffung und Informationserzeugung, Informationsmanagement und Informationsorganisation, Informationsverwertung und Informationsmärkte, Anwendungsprojekt, Seminar aus Informationswirtschaft.

15 Praktika sind vorgesehen als Anwendungsprojekt in einer Programmiersprache.

16 Am Ende des Studiums der speziellen Betriebswirtschaftslehre ist eine schriftliche und eine mündliche Diplomprüfung abzulegen.

173 Semester; Regelstudienzeit 3 bis 4 Semester.

18 Organisationsprogrammierer, Systemanalytiker, EDV-Vertriebsbeauftragte, Informationsmanager, Datenbank- und Unternehmensadministrator und Wissensingenieur.

! Der Einfluß der Information auf das Wirtschaftsgeschehen ist stetig im Steigen begriffen. Die ab dem Wintersemester 1990/91 von der Abteilung für Angewandte Informatik insbesondere Betriebsinformatik des Instituts für Informationsverarbeitung und Informationswirtschaft erstmals angebotene besondere Betriebswirtschaftslehre Informationswirtschaft trägt dieser Entwicklung Rechnung, indem sie Information zum Gegenstand betriebswirtschaftlicher Forschung und Lehre macht.

\section{ACADEMIC SUBJECT: COUNTRY: CITY, INSTITUTION:} Information Management

France

Paris, Institut National des Sciences et Technique de l'Information (INTD-CNAM) (p. 23) 
08 3ème cycle; temps plein

09 Cette formation s'adresse à des étudiants français ou étrangers diplômés des Grandes Ecoles (scientifiques ou de gestion); titulaires de diplômes universitaires de niveau équivalent $(\mathrm{bac}+5)$ dans les domaines scientifique et technique, économique de l'INTD qui justifient obligatoirement une expérience professionnelle en entreprise.

10 Délai à observer du ler Juni au ler Septembre; 12 étudiants sont admis chaque année pour le Mastère.

1116 Novembre

12 L'INTD, fort d'une position de leader acquise depuis quarante ans dans le domaine de la formation aux techniques documentaires les plus récentes et au traitement avancé de l'information, propose une spécialisation sur les questions de veille stratégique en entreprise. Ce Mastère a comme objectif de former au plan national des personnes ayant déjà une expérience professionnelle, ou d'améliorer la formation des titulaires de diplômes universitaires.

13 La formation se déroule sur 8 mois sous forme de séminaires d'une semaine par mois. Cela équivaut à 250 heures de séminaires et de travaux dirigés, sans compter les travaux personnels et d'équipe, le stage et la réalisation de la thèse.

14 Connaissance de l'entreprise; Techniques et méthodes de traitement de l'information; Organisation d'une fonction de veille; Maîtrise et développement des outils informatiques; Acquisition de méthodes; Stage en entreprise; La thèse professionnelle

15 Des stages sont prevus pour tous les cycles.

$17 \quad 1$ an

ACADEMIC SUBJECT: Information Management COUNTRY: CITY, INSTITUTION:

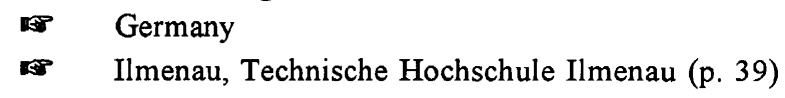

07 Diplom Wirtschaftsinformatiker; Fachinformator

08 1. Ebene; Vollzeitstudium; Wahlpflichtfach ist Informationsmanagement / Informationswissenschaft

09 Allgemeine Hochschulreife oder eine vom Landesministerium als gleichwertig anerkannte Hochschulzugangsberechtigung.

11 Jeweils zum Sommer- oder zum Wintersemester.

12 Aufbau, Entwicklung und Implementierung von Wirtschafts- und Fachinformationssystemen. Entwicklung von Unternehmensinformationskonzepten. 
13 Gliederung in ein Grund- (4 Semester) und ein Hauptstudium (5 Semester). Wahlpflichtkombination ab dem 5. Semester

14 Kombination von Informatik-, Wirtschaftsinformation- und informationswissenschaftlichen Fächern; Projektarbeit

Zusatzstudium Fachinformation: Grundlagen, Bedarfsanalyse und Resourcenmanagement; spezielle Informations- und Kommunikationssysteme; Informationsquellen; Inhaltliche Erschließung; Information Retrieval; Spezielle Fachinformationsdienste und -leistungen; Projektarbeit

15 Insgesamt 36 Wochen mit individueller Gestaltung müssen abgeleistet werden.

16 Vordiplomprüfung nach dem 4. Semester.

179 Semester; Zusatzstudium Fachinformation: 3 semestriges Korrespondenzstudium mit monatlichen Konsultationstagen oder einsemestriges Direktstudium.

ACADEMIC SUBJECT: COUNTRY: CITY, INSTITUTION:

\author{
Information Management \\ $\leftarrow$ The Netherlands \\ Maastricht, Rijkshogeschool Maastricht (p. 54)
}

07 Hoger Beroepsonderwijs (HBO) in Information Resource Management

08 1st level; full-time

09 To qualify for admission to Hoger Beroepsonderwijs (HBO) in the Netherlands, students must have a diploma from one of several types of secondary-schools: "VWO" diploma (Voorbereidend Wetenschappelijk Onderwijs = pre-university education: 6 years after 6 years of primary education), or the "HAVO" diploma (Hoger Algemeen Voortgezet Onderwijs = general secondary education, higher level: 5 years after 6 years of primary education), or an appropriate "MBO" diploma (Middelbaar Beroeps Onderwijs = secondary vocational education, intermediate level: 3 or 4 years after 6 years of primary education). Applicants over the age of 21 who does not possess one of the above diplomas may be granted admission on the basis of other evidence which proves that they have the background knowledge necessary for HBO study (" 21 + entrance examination").

11 September of each year.

12 Educating students for functions in Information Management.

14 The following modules are taught: Introduction Information Resource Management, Computerized Information Processing, Documentary Information Systems; Economics of Information I+II, Management/Information Resource Management, Management II, Projectmanagement, Databases and Database Management, Systems Development, Office Management and Telematics, Organization of Administration, Staff Management, 
Research Methodology, Strategic Management, Information Management, Oral and Written Communications

15 Practical studies are intended; practical work can be carried out in a broad variety of organizations; practical studies can be possible in USA, UK, Germany and Belgium.

16 By the end of each module; several exams have to be passed.

174 years

18 A wide variety of jobs in the information field (Librarian, Documentalist, Information Manager, System Analyst etc.)

\begin{tabular}{ll} 
ACADEMIC SUBJECT: & \multicolumn{2}{l}{ Information Management } \\
COUNTRY: & Northern Ireland \\
CITY, INSTITUTION: & Belfast, Queen's University of Belfast (p. 55)
\end{tabular}

07 Diploma, Master of Science (MSc) in Information Management

08 2nd level; full-time

09 Candidates must be graduates of this or any other approved university or recognized institution (or expect to graduate before the course commences).

10 Applications must be received by March first to be considered for admission in September.

11 September of each year.

12 The course is accredited by the Library Association but is primarily intended to equip students to work in a wide range of occupations involving the management of information.

13 Two semesters (September-January and February-May): 5 courses in each semester (lectures, seminars and practicals). 1 short project. Dissertation: June-September for MSc.

14 Information Resources Management, Information Technology I+II, Marketing, Organizational Behaviour, Systems Analysis and Design, Information Management in Practice, Business Information Resources I+II, Communicating and Presenting Information, Project.

15 Information technology practicals are included.

16 All courses are assessed on the basis of work submitted.

178 months Diploma, 12 months MSc 
18 Librarians and Information Officers

! This University is Member of British Association for Information and Library Education (BAILER) and Research and of European Association for Library and Information Education and Research (EUCLID).

ACADEMIC SUBJECT: COUNTRY:

CITY, INSTITUTION:

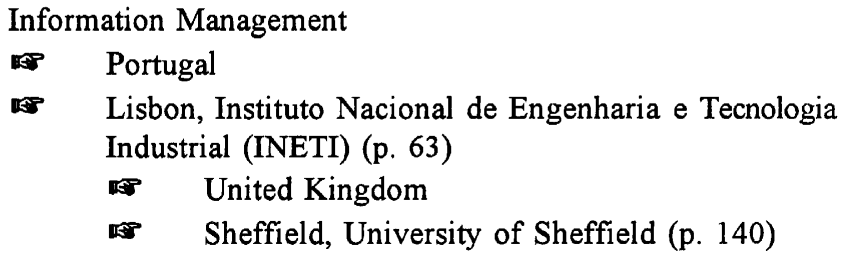

ACADEMIC

CITY, INSTITUTION:
St. Gallen, Hochschule St. Gallen (p. 79)

07 Lizeniat der Wirtschaftswissenschaften Hochschule Sankt Gallen (lic.oec. HSG), Doktor der Wirtschaftswissenschaften Sankt Gallen (Dr. oec. HSG) in Information and Technology Management

08 1st level; full-time

09 Passing an entrance examination for foreigners with no Swiss Matura.

11 In October of each year.

12 The graduates are educated to support general and line management in identifying new information technology based business solutions and in transforming them into design and development processes.

134 half-years of basic studies; 4 half years of specialized studies in Information Management.

14 Basic studies: Business Administration, Economy, Law, spezialized studies: Information Technology, Systems Engineering, Quality Managment, Innovation Managment, Office Automation, Information Resource Management, Organization and Information Processing.

15 A half-year pratical study is intendet.

16 After the second term "Vordiplomprüfung Part I"; after the fourth term "Vordiplomprüfung Part II"; term 5 til 8 four "qualifizierte Testate"; after the eight term Diplomprüfung Part II.

174 years 


\begin{tabular}{ll} 
ACADEMIC SUBJECT: & \multicolumn{2}{l}{ Information Management } \\
COUNTRY: & United Kingdom \\
CITY, INSTITUTION: & Glasgow, University of Strathclyde (p. 85)
\end{tabular}

07 Master of Science (MSc), Postgraduate Diploma in Information Management

08 2nd level

09 Diploma/Master of Science; Honours Degree of Equivalent

11 September

12 To create graduates capable of working in a wide range of information careers in the public and private sectors.

14 Information Resource Management; Information Policy and Economics; Information Technology, Systems and Services; Information Processing Applications; Information Networks; Knowledge Management

15 Software applications packages for all courses for 3 weeks in library or information services.

16 Examination in all classes, taken in May/June

18 Range of professional information posts in public and private sectors.

$\begin{array}{ll}\text { ACADEMIC SUBJECT: } & \text { Information Management } \\ \text { COUNTRY: } & \text { United Kingdom } \\ \text { CITY, INSTITUTION: } & \text { Manchester, Manchester Metropolitan University (p. 91) }\end{array}$

07 Master of Science (MSc) in Information Management

08 2nd level; full-time

09 Applicants are normally required to have a degree in any subject of a university in the United Kingdom or of the CNAA. Applicants with other qualifications or other university degrees are considered on their merits.

12 Course aims are to develop the students' knowledge and skills to: manage and develop information systems and resources, using appropriate information technologies in support of organisational objectives, and cope with contigent change and to implement directed change in the management of information within their organizations. Course specific objectives are to enable the student to understand the role of information in the achiement of organizational objectives, understand the process and management of change in 
organizations, identify corporate, sectional and individual information needs, devise appropriate systems to faciliate the satisfaction of these needs, develop competences in analysing synthesising and presenting information, analyse and evaluate developments in information technology applicable to the managment of information.

13 The course is offered on a structured modular basis. There are ten taught modules and the final integrating element. Either a Major Project or Review and Evaluation.

14 Information Resources; Organizations as Information Processing Systems; Records Management; Systems Investigation and Development; Investigating Systems; The Organization and its Environment; Systems Monitoring; Enabling Technologies; Study Areas; Management of Change; Review and Evaluation; Major Project.

173 years

18 Major concerns of information managers are the application of management skills; the information resources available to organizations; and the application of appropriate information technologies.

! The tuition fee for $1992 / 1993$ is $£ 396$ per year. All students pay a conferment fee of $£$ 12 at the start of the course. The tuition fee for year 2 is $£ 396$ and for year $3 £ 132$.

ACADEMIC SUBJECT:

\section{COUNTRY}

CITY, INSTITUTION:

\section{Information Management}

United Kingdom \& Portugal

Sheffield, University of Sheffield (p. 93) \& Lisbon, Instituto Nacional de Engenharia e Tecnologia Industrial (INETI) (p. 63)

07 Master of Science (MSC) in Information Management

09 Licenciatura (4 to 5 years course at University) and good knowledge of English language; 25 to 30 students can start studies each term.

10 There is a deadline for enrolment; please ask the secretary.

11 The date for starting studies varies.

12 The Master of Science in Information Management, based in INETI is an expeiment: it is an experiment in international cooperation, an experiment in cooperation between an educational institution and a research and development organization, and it is an experiment in teaching methods. We expect success, but we also expect that problems will arise, both educationally and organizationally.

The programme offers a unique opportunity for you to gain an understanding and awareness of the newly emerging field of Information Management. We live in an "Information Age" and, increasingly, organizations of all kinds are looking for people with a broad appreciation of the benefits that computer-based information systems can bring. 
13 The course consists of five dual modules and a single module on research methods. These modules are taught in four terms.

14 Information Management I+II; Information Services I+II; Computers and Information I+ II; Information and Database Systems I+II; Information Storage and Retrieval I+II; Research Methods for Information Management

15 Practical work is intended; practical studies can be carried out by microinformatics Laboratory or stages in companies or other organizations.

16 Each student is assessed through coursework produced for each module and the final dissertation.

1718 months

18 Students get jobs in information related jobs in a variety of organizations (Industrial Associations, Banks, etc.).

! The students are registerd for the degree at the University of Sheffield, but the course takes place in Lisbon, on the premise of INETI, at Lumiar.

ACADEMIC SUBJECT: COUNTRY: CITY, INSTITUTION:

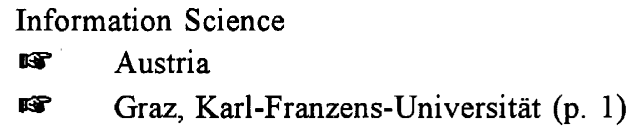

07 Magister Artium (MA) der Sozial- und Wirtschaftswissenschaften / Dr. der Sozial- und Wirtschaftswissenschaften in Informationswissenschaft

08 2. Ebene; Vollzeitstudium; 1. Betriebswirtschaftslehre (BWL), Volkswirtschaftslehre (VWL) und Wirtschaftspädagogik mit Informationswissenschaft als Wahlpflichtfach; 2. Volkswirtschaftslehre (VWL) und Wirtschaftspädagogik mit Informationswissenschaft als Wahlfach; 3. Soziologie mit Informationswissenschaft als Fächerkombination

09 Nachweis der Hochschulreife und Hochschulberechtigung und Abschluß des 1. Studienabschnitts des jeweiligen Studiengangs (Betriebswirtschaftslehre (BWL), Volkswirtschaftslehre (VWL), Wirtschaftspädagogik, Soziologie).

10 Es gibt keine klassische Bewerbungsfrist. Die Lehrveranstaltungen beginnen jeweils Anfang Winter- und Sommersemester, also Anfang Oktober und Anfang März. Die Vorlesungen der Informationswissenschaft sind frei zugänglich, lediglich für die Proseminare besteht eine Anmeldepflicht. Die Anmeldefrist beginnt 14 Tage vor dem Start der Lehrveranstaltungen. Die Teilnehmerzahl ist auf ca. 25 Studenten begrenzt.

11 Die Möglichkeit zur Ausbildung innerhalb der Informationswissenschaft besteht nur für Studenten im zweiten Studienabschnitt der Studienrichtungen Betriebswirtschaftslehre, 
Volkswirtschaftslehre, Wirtschaftspädagogik und Soziologie. Die Studenten müssen also bereits in diesen Fächern immatrikuliert sein.

12 Untersuchung von Informationsprozessen und -problemen in Wissenschaft, Gesellschaft, Wirtschaft und Verwaltung; Vermittlung der Methoden und Werkzeuge der Information, Dokumentation und Kommunikation sowie der Grundsätze des wirtschaftlichen Umgangs mit Information.

13 1. Wahlpflichtfach Betriebswirtschaftslehre: 2 Grundvorlesungen, 2 Spezialvorlesungen, 3 Proseminare; 2. Wahlpflichtfach Volkswirtschaftslehre: 2 Grundvorlesungen, 2 Spezialvorlesungen, 3 Proseminare; 3. Wahlpflichtfach Wirtschaftspädagogik: 2 Grundvorlesungen, 2 Spezialvorlesungen, 3 Proseminare; 4 . Wahlfach Volkswirtschaftslehre: 2 Grundvorlesungen, 1 Spezialvorlesungen, 2 Proseminare; 5 . Wahlfach Wirtschaftspädagogik: 2 Grundvorlesungen, 1 Spezialvorlesungen; 6. Im Rahmen der Fächerkombination Soziologie

14 Grundvorlesung Informationsvermittlung: Grundbegriffe der Dokumentation; Informationsbanken; Netze; Präsentation von Information; Grundvorlesung Information Management (IM): Grundbegriffe des IM; Kommunikations-Management; Informationsressourcen-Management; Informationsverarbeitungs-Management; die Praxis des IM; Grundvorlesung Sozio-ökonomisches Umfeld: Rechtsfragen; Informationsmarkt; Geschichte des Faches; Spezialvorlesung Dokumentationsmethoden: Methoden des Information Retrieval; Aufbau und Betrieb von Datenbanken; Spezialvorlesung Elektronisches Publizieren: Schreiben am Computer; Elektronische Manuskripte; Verlage und elektronische Publikationen; Nutzen elektronischer Publikationen; Elektronisches Publizieren in der Fachkommunikation; Spezialvorlesung Fachinformation: Bibliotheks- und Dokumentationswesen; Datenerschließung und -aufbereitung, Elektronische Datenverarbeitung im Bibliothekswesen. Zur Vertiefung des Lehrstoffes werden Seminare und Übungen aus den Teilgebieten Elektronische Datenverarbeitung, Informationsmanagement und IDB (Information, Dokumentation und Bibliothek) angeboten: Information, Dokumentation und Bibliothek: Information Retrieval; Nutzung von Informationssystemen; Aufbau von Informationssystemen; Informationsmanagement: Datensicherheit; Information im Unternehmen; Elektronische Datenverarbeitung: Software-Engineering; Datenbanksysteme; Konzeption von Anwendungssystemen.

15 Praktika sind nicht vorgesehen.

16 Studenten der Betriebswirtschaft müssen im Rahmen ihrer informationswissenschaftlichen Ausbildung vier Vorlesungen und drei Proseminare absolvieren, um zur Diplomprüfung antreten zu dürfen. Die Prüfung besteht aus einem schriftlichen und einem mündlichen Teil und findet an vier Terminen pro Studienjahr statt.

173 bis 4 Semester

18 Die Absolventen finden überwiegend Beschäftigung als Betriebswirte. 


$\begin{array}{ll}\text { ACADEMIC SUBJECT: } & \text { Information Science } \\ \text { COUNTRY: } & \text { Czech Republic } \\ \text { CITY, INSTITUTION: } & \text { Praha, Univerzita Karlova (p. 6) }\end{array}$

07 Bachelor of Arts (BA), Master of Arts (MA) in Information Science and Librarianship, Doctor of Philosophy (PhD) in Librarianship

$08 \quad 1$ st, 2nd and 3rd level

09 Applicants are expected to have the A-level in secondary education or some kind of higher education.

11 Applicants should be submitted before 31st of February of each year.

12 To prepare graduates for a wide range of careers in the library and information systems here.

14 Social Sciences Background, Library and Information Science Background, Foreign Languages, Librarianship, Bibliology (Historical Bibliography), options (lectures or seminar): Theory and Practice of Contemporary Information Activities, Marketing, Scientometrics and Bibliometrics, Informatization of Society, Algebraic Linguistics and Machine Translation, Personal Documentation for Scholars and Specialists, Standardization and Patent Information, Creativity, Comparative Librarianship, Reader Psychology, Sociology of Reading, Children's Literature, Work with Children and Young People, Contemporary Czech and Slovak Literature, Music Librarians, Book Illustration and Typography, Manuscript Illustration, Czechoslovak Publishers and Booksellers in the 17 th and 18 th centuries.

15 Practical studies are intended; practical studies can be carried out by the three-week training stay managed by some specialist and supervised by the department.

16 By the end of the 4th study year students must pass examinations in three languages (1 major, 2 minor): selection: English, German, French, Russion, Latin. Requirements in specializations: Scientific information: major exam in English; Bibliology: major exam in German, minor exam in Latin.

$17 \quad 4-5$ years

18 Librarian-specialists; managers and key-workers in libraries, information centers and other information institutions

! It is to stress that we are now in the process of the new curriculum creating. One of the biggest changes will be the experiment with the MA studies for the BA students from other faculties and universities. Entrance without fees. 
ACADEMIC SUBJECT:

COUNTRY:

CITY, INSTITUTION:

\author{
Information Science \\ France \\ Bordeaux, Université Michel de Montaigne- \\ Bordeaux III (p. 14)
}

07 Maîtrise de Sciences de l'Information et de la Documentation

09 Licence plus Module de Documentation.

10 Il y a un délai à observer pour l'inscription.

11 1er novembre.

15 Stages sont possibles.

161 an

18 Documentaliste

ACADEMIC SUBJECT:

COUNTRY:

Information Science

CITY, INSTITUTION:

France

Lyon, Université Jean-Moulin-Lyon III (p. 18)

07 Maîtrise des Sciences de l'Information et de la Documentation

08 2ème cycle; temps plein

09 Tout étudiant ayant obtenu soit une Licence avec la mention Documentation soit la Licence des Techniques d'Archives et Documentation est autorisé às'inscrire en Maîtrise. A titre dérogatoire, les étudiants titulaires d'une Licence et qui ont suivi, avec succés, le module de Documentation de niveau Licence sont aussi autorisés à s'inscrire en Maîtrise.

10 Mai

11 Octobre

12 A l'issue de cette formation, les étudiants doivent être aptes à concevoir et gérer des services et systémes d'information spécialisée. Ces étudiants devront, non seulement, être capables de maîtriser les outils et techniques de recherche, d'élaboration et de diffusion de l'information, mais aussi, disposer des connaissances minimales en communication, linguistique, psychologie, informatique, économie et sociologie pour leur permettre de faire évoluer ces outils et ces techniques. 
14 Histoire de la circulation des idées et des connaissances; Approche théorique de l'information et de la cognition; micro-économie et information; Recherche et transmission de l'information; Analyse et représentation de l'information; Sciences et technologies de l'information; Bases de données et bases de connaissances; Analyse et évaluation des besoins en information; Conception et management d'un système d'information; Droit de l'information; Anglais spécialisé.

15 A l'issue de la période d'enseignement, chaque étudiant doit faire un stage de trois mois en entreprise et mener à bien un travail précis proposé par celle-ci.

16 Les modalités précises de contrôle des connaissances sont fixées par les conseils de Faculté et d'Université.

172 ans

ACADEMIC SUBJECT:

COUNTRY:

CITY, INSTITION:

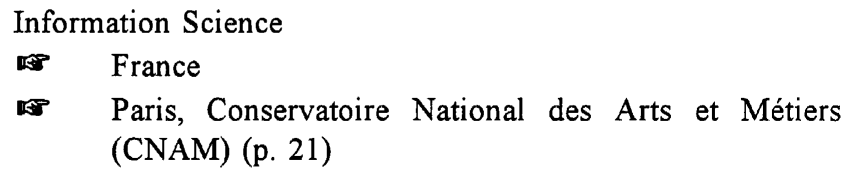

07 Diplôme d' Etudes Approfondies (DEA) en Information Scientifique et Technique (IST)

083 3ème cycle; temps plein/temps partiel

09 Maîtrise $(\mathrm{Bac}+4)$ scientifique (les Maîtrises de sciences humaines ne sont pas actuellement acceptées); Ingénieur

1030 juin

11 Début novembre

12 Formation à la recherche; enseignants-chercheurs; ingénieurs de recherche

$14 \underline{\text { ler semestre }}=$ tronc commun. 2ème semestre $=$ options: Systèmes et produits d'information, Informatique pour l'information. 9 matières sont nécessaires pour être diplômé.

15 Un stage: 6 mois à partir de janvier à mi-temps (3 jours par semaine); possibilité d'aller à l'étranger.

169 examens: 4 en février et 5 en juin

171 an à temps plein/2 ans à temps partiel

185 préparent un doctorat; 12 font du développement dans des entreprises informatiques. 
ACADEMIC SUBJECT:

Information Science

COUNTRY:

France

CITY, INSTITUTION: Paris, Institut National des Techniques de la Documentation (INTD-CNAM) (p. 23)

07 Diplôme supérieur des Sciences et Techniques de l'Information et de la Documentation

08 3ème cycle; temps plein

09 Diplôme de fin d'études du deuxième cycle universitaire $(b a c+4)$ ou licence et trois années d'activité professionnelle en tant que cadre.

10 Les dossiers d'inscription peuvent être retirés du 1er Juni au 1er Septembre au secrétariat de l'INTD; 66 étudiants sont admis chaque année pour le cycle supérieur.

118 Octobre

12 A l'issue de leur formation, les élèves ajoutent à leur compétence première dans un domaine des sciences humaines ou exactes ou dans un secteur d'activité la maîtrise des concepts, des méthodes, des technologies et du managament du traitement de l'information. Ils sont capables de conduire des projets, de gérer un centre de documentation ou d'information, d'élaborer des produits d'information et de communication, et de les diffuser.

13 Formation en un an à temps plein-ou en deux ans à temps partiel pour les cadres envoyés par leur entreprise, associant des enseignements théoriques, des nombreux travaux dirigés, des projets, individuels ou en groupe, en relation directe avec la vie professionnelle, des stages en entreprises et un mémoire de fin d'études.

14 Le Traitement de l'Information; La Recherche de l'Information; La Communication et le Management; Les Technologies de l'Information; L'Informatique; la Télématique et la Bureautique

15 Des stages sont prevus pour tous les cycles.

$17 \quad 1$ an

ACADEMIC SUBJECT:

COUNTRY:

CITY, INSTITUTION:
Information Science

France

Paris, Université Paris Nord-Paris XIII (p. 27)

07 Licence, Maîtrise des Sciences de l'Information et de la Communication

08 2ème cycle; temps plein 
09 Etudiants étrangers: Contacter le service des équivalences de l'UFR (Unité de Formation et de Recherche) concernée.

10 Septembre

11 Octobre

17 Une année Licence, une année Maîtrise.

$\begin{array}{lll}\text { ACADEMIC SUBJECT: } & \text { Information Science } \\ \text { COUNTRY: } & \begin{array}{l}\text { Germany } \\ \text { Berlin, Freie Universität, Arbeitsbereich Informations- } \\ \text { wissenschaft (p. 30) }\end{array}\end{array}$

07 Magister Artium (MA); Doktor der Philosophie (Dr. phil) in Informationswissenschaft

08 2. und 3. Ebene; IW im 1. und 2. Hauptfach, Nebenfach oder Zusatzstudium

09 Allgemeine oder fachspezifische Hochschulreife; universitätsinterne Zulassungsbeschränkung

11 Jeweils im Wintersemester; alle Zulassungsfragen behandelt das Zulassungsbüro der Freien Universität Berlin, Boltzmannstr. 3, D-14195 Berlin.

12 Die Informationswissenschaft befaßt sich mit der Erforschung der Grundlagen der systematischen, kontinuierlichen Organisation von Kommunikationsprozessen mit dem Ziel der bedürfnisbezogenen Information von Individuen, Gruppen, Organisationen und der Gesellschaft als Ganzem. Von besonderer Bedeutung ist hierbei die Untersuchung der Einsatzbedingungen und Anwendungsmöglichkeiten von Informations- und Kommunikationstechnologien. Sie nimmt derart eine Brückenfunktion zwischen den betreffenden Ingenieur- und Kommunikationswissenschaften wahr. Die Brückenfunktion ist von dem sozialwissenschaftlichen Ansatz der Informationswissenschaft geprägt. Das Studium der Informationswissenschaft soll dazu befähigen 1. Prozesse der Informations- und Wissenspräsentation, Informations- und Wissensspeicherung, -repräsentation, -vermittlung und des Austauschens von und Zugriffs auf Informationen und Wissen systematisch zu organisieren, 2. Systeme, die dazu dienen, zu analysieren, zu kritisieren, zu entwerfen und zu implementieren. Dabei soll der jeweils neueste Stand der infragekommenden Technologien ebenso einbezogen werden wie andere technische oder nicht-technische Lösungen.

13 Der Teilstudiengang im Magisterstudium ist kombinierbar mit über 50 überwiegend geistes- und sozialwissenschaftlichen Fächern. Der Magisterstudiengang ermöglicht entweder zwei Hauptfächer oder ein Haupt- und zwei Nebenfächer. Einziges Kombinationsverbot: Informationswissenschaft und Publizistik als zwei Hauptfächer. Informationswissenschaft im Nebenfach ist mit folgenden Fächern sinnvoll und möglich: Informatik, BWL/VWL, Linguistik/Semiotik, Publizistik, Soziologie. 
14 Informationswissenschaft als Hauptfach: 1. Pflichtveranstaltungen (Grundstudium): Einführung in die IW I+II; Einführung in die Informationstechnik I+II; Proseminare Technik; Proseminare Theorie; 2. Wahlveranstaltungen (Grundstudium): Grundlagen und Methoden aus Linguistik/Semiotik/Logik. Grundlagen und Methoden aus Sozialforschung/Wirtschaftswissenschaften; Grundlagen und Methoden aus den historischen/ hermeneutischen Wissenschaften; Grundlagen und Methoden aus den Natur- und Ingenieurwissenschaften; 3. Schwerpunkte im Hauptstudium: Informations- und Kommunikationsmanagement; Wissensbasierte Systeme; Technikfolgenabschätzung; Visuelle Kommunikation und elektronisches Publizieren

Informationswissenschaft als Nebenfach: Veranstaltungen im Grundstudium: Einführung in die IW; Proseminare in Technik; Proseminare in Theorie/ Veranstaltungen im Hauptstudium: Theorie und Methodik der Informationswissenschaft I+II; Grundlagen der Informationsvermittlung/Wissensorganisation und -repräsentation; Überblick über Informations- und Kommunikationstechnologien; Informations- und Kommunikationsmanagement; Gesellschaftliche Aspekte des Einsatzes von Informations- und Kommunikationstechnologien; Kulturelle Aspekte des Einsatzes von Informations- und Kommunikationstechnologien; Methodik der Einsatzforschung.

15 Praktika sind in den Studienordnungen nicht vorgesehen, werden den Studierenden aber in der Beratung empfohlen und werden - nach Prüfung der Gleichwertigkeit - auch auf das Studienprogramm angerechnet (jeweils im Einzelfall gemäß der geltenden Gleichstellungsregelungen). Im Einzelfall können Studenten bei Bedarf auch bei der Praktikumsstelle unterstützt werden (etwa durch Empfehlungsschreiben).

16 Den Abschluß des Grundstudiums bildet die Zwischenprüfung. Den Abschluß des Hauptstudiums bildet die Magisterprüfung bzw. die Nebenfachprüfung im Rahmen der Magisterordnung.

17 Die Regelstudienzeit beträgt 9 Semester. Dabei ist von 8 Semestern Studium und einem Semester für die Magisterprüfung auszugehen. Die durchschnittliche Studiendauer beträgt (1992) 15,1 Semester.

18 Das Spektrum reicht von Anstellungen in Software-Firmen über Unternehmensberatungen bis zum Museumswesen.

\author{
ACADEMIC SUBJECT: Information Science \\ COUNTRY: \\ CITY, INSTITUTION: Bielefeld, Universität Bielefeld (p. 34)
}

07 Diplom in Sozial- und Erziehungswissenschaft (DSE)-Wahlpflichtfach;Richtung: Informatik im Bildungs- und Sozialwesen; Promotion (nach vorherigen Abschluß)

08 2. Ebene; Vollzeitstudium

09 Allgemeine Hochschulreife; keine Zulassungsbeschränkung; keine Beschränkung bei den Neuaufnahmen pro Semester. 
11 Sowohl zum Sommer- als auch zum Wintersemester

12 Es sollen pädagogisch relevante Grundkenntnisse und Grunderfahrungen in der EDV und der in pädagogischen Handlungsfeldern einsetzbaren Hard- und Software vermittelt werden.

13 Grundlagenbereich: 6 SWS (Problemfeld A), 2 SWS (Problemfeld E); weiterführender Bereich: 2 SWS (Problemfeld B), 6 SWS (aus den Problemfeldern und aus D); Wahlbereich: 4 SWS (aus dem Lehrangebot der Informatik im Bildungs- und Sozialwesen)

14 A: Grundlagen der Informatik für Pädagogen; B: Standardanwendungen in pädagogischen Aufgabenbereichen; C: Informatik in schulischen und außerschulischen Lehr- und Lernprozessen; D: Informatik in Erziehungs-, Beratungs-, und Bildungseinrichtungen; E: Informatik und Gesellschaft

15 Praktika sind vorgesehen.

16 Im Grundstudium muß ein und im Hauptstudium müssen zwei Leistungsnachweise erworben werden.

179 Semester (140 SWS)

18 EDV-Leiter, Beauftragter im Bildungs- und Erziehungswesen

\begin{tabular}{lll} 
ACADEMIC SUBJECT: & \multicolumn{2}{l}{ Information Science } \\
COUNTRY: & $\begin{array}{l}\text { Germany } \\
\text { CITY, INSTITUTION: }\end{array}$ & $\begin{array}{l}\text { Düsseldorf, Heinrich-Heine-Universität Düsseldorf } \\
\text { (p. 36) }\end{array}$
\end{tabular}

07 Magister Artium (MA); Doktor der Philosophie (Dr. phil) in Informationswissenschaft

08 2. Ebene; Vollzeitstudium; Informationswissenschaft im Nebenfach und kann mit folgenden Hauptfachstudiengängen kombiniert werden: Philosophie, Geographie, Erziehungswissenschaft, Sozialwissenschaft, Geschichte, Kunstgeschichte, Allgemeine Sprachwissenschaft, Klassische Philologie, Germanistik, Anglistik und Romanistik.

09 Allgemeine Hochschulreife

10 Die Einschreibung für das Fach IW im Magisterstudiengang setzt die Immatrikulation an der Philosophischen Fakultät für ein Hauptfach und ein weiteres Nebenfach voraus. Studierende an anderen Universitäten können in Düsseldorf als Zweithörer für das Nebenfach IW eingeschrieben werden, wenn die Universität des Hauptfaches dies zuläßt.

11 Nur zum Wintersemester (bis 1. Oktober eines jeden Jahres).

12 Das Studium der IW ist gerichtet auf die systematische Behandlung von Informationsprozessen und -systemen in Wissenschaft, Wirtschaft und Verwaltung. Im Vordergrund 
steht die Vermittlung von konzeptionellem, methodischem und technischem Wissen zur Analyse, Verwaltung, Zugänglichkeit und Verarbeitung von Informationen.

13 Grundstudium (vier Semester mit 26 SWS), Hauptstudium (vier Semester mit 14 SWS). $\mathrm{Zu}$ belegen sind 40 Semesterwochenstunden (SWS).

14 Lehrgebiete der Übersichtsvorlesungen im Grundstudium: Einführung in die Informationswissenschaft; Fachkommunikation und Literaturdokumentation; Wissensorganisation; Technologie der Fachinformation; Lehrgebiete der Übersichtsvorlesungen im Hauptstudium: Informationsmanagement; Informationsbedarf und -verhalten; Informationsökonomie; Information und Gesellschaft;

Folgende Vorlesungen können wahlweise im Grund- oder Hauptstudium besucht werden: Internationale Informationsorganisation und -politik; Faktendokumentation und Retrieval; Einführung in die wissensbasierte Informationsverarbeitung ("künstliche Intelligenz"); Datenorganisation.

$\mathrm{Zu}$ den Vorlesungen werden inhaltlich bezogene Seminare angeboten.

15 Am Ende des Grundstudiums ist ein mehrwöchiges Praktikum in Fachinformationseinrichtungen bzw. in Informationsabteilungen von Unternehmen, Behörden, Verbänden etc. vorgesehen, das die Studierenden mit den Bedingungen der Praxis ihrer künftigen Arbeitswelt bekannt machen will. Für die Vermittlung der Praktikanten steht eine Datenbank zur Verfügung.

16 Nach dem Grundstudium Zwischenprüfung; am Ende des Hauptstudiums Teilprüfung im Rahmen der Magisterprüfung.

17 Regelstudienzeit: $8+1$ Prüfungssemester

18 Das Studium der IW will auf eine Berufstätigkeit in den Bereichen Information und Dokumentation vorbereiten, so vor allem in Fachinformationszentren, in den Dokumentationsstellen der Wissenschaft und Wirtschaft, in innerbetrieblichen Informationseinrichtungen und solchen von Behörden, von Verbänden und Stiftungen, in Verlagen, Pressehäusern, Rundfunk- und Fernsehanstalten, in Informationsvermittlungsstellen von wissenschaftlichen und öffentlichen Bibliotheken, Handelskammern, Technologietransferund -beratungssinstituten etc. sowie im Fortbildungsbereich. Weiterhin ist der Lehrstoff auf das Aufgabenfeld eines Informations-Managers in Forschungseinrichtungen, Wirtschaftsunternehmen und Behörden bzw. im Bereich der Unternehmens- und Innovationsberatung ausgerichtet.

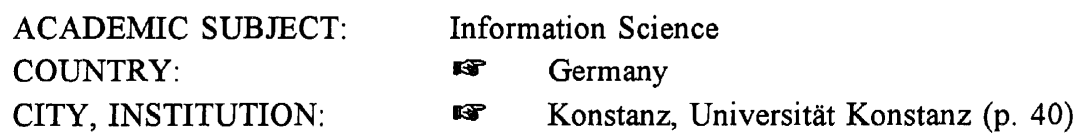

08 3. Ebene; Vollzeitstudium 
09 Ein abgeschlossenes Hochschulstudium muß nachgewiesen werden; die Auswahl der Studierenden erfolgt nach dem gültigen Verfahren der Zulassungsabteilung der Universität. Dabei ist vor allem die Gesamtnote des Primärstudiums entscheidend. Diese muß in der Regel mindestens "gut" betragen.

10 Bewerbungsfrist bis zum 15. Juli eines jeden Jahres.

11 Jeweils zum Wintersemester.

12 Das Aufbaustudium Informationswissenschaft will in der Kombination mit dem Erststudienfach eine Weiterqualifikation in den Vertiefungsrichtungen Informationsvermittlung, Informationsmanagement und wissensbasierte Informationssysteme ermöglichen.

134 Semester Regelstudienzeit inkl. 3 Monate Praxisaufenthalt nach dem zweiten Semester. Im ersten Semester sind Grundkurse und Pflichtkurse zu besuchen. Ab dem zweiten Semester werden Wahlpflichtkurse, Spezialkurse und freie Wahlpflichtkurse besucht. Für das dritte Semester sind Wahlpflichtkurse und Spezialkurse vorgesehen, außerdem können Projektkurse besucht werden.

14 Grundkurse: Einführung in die Informationswissenschaft; Informations- und Kommunikationstechnologien; formale Systeme; Betriebwirtschaftlehre für die Informationswissenschaft. Pflichtkurse: Informationsvermittlung; Informationsmanagement; Wissensbasierte Informationssysteme 1: Modellierungsmethoden. Wahlpflichtkurse: Informationsvermittlung,Informationsmarkt; Informationsaufbereitung; Informationsmanagement; Datenbanksysteme; Wissensrepräsentation; Modellierung von Informationssystemen. Spezialkurse Informationsvermittlung: Automatische Verfahren der Dokumentenrepräsentation; Kurse zu Programmiersprachen; Multimediale Anwendungen; Informationsvermittlung-Projektkurse. Spezialkurse Informationmanagement: Strategische Informationsplanung; Datenmodellierung, Metainformationssysteme; Datenbanksysteme 2; IM-Projektkurse. Spezialkurse wissensbasierte Informationssysteme: Wissensrepräsentation 2; Wissensbasierte Informationssysteme 2; Kurse zu wissensbasierten Programmiersprachen; Seminar zu wissensbasierten Informationssystemen; Wissensbasiserte Informationssysteme-Projektkurse. Gebietsübergreifende Spezialkurse: Informationsmarketing, Management von Informationsorganisationen, Information und Gesellschaft; Entwurf von Benutzerschnittstellen

153 Monate Praxisaufenthalt in einer einschlägigen Institution.

1611 Leistungsnachweise, am Ende des Studiums Diplomarbeit und mündliche Prüfung.

17 Regelstudienzeit 4 Semester, durchschnittliche Studiendauer 6 Semester

18 Der Karriereeinstieg der ersten 19 informationswissenschaftlichen Absolventen gelang in folgenden Tätigkeiten: DV-Ausbildung (2), Unternehmensberatung, wissenschaftliche Mitarbeit (2), Entwicklung von Büroretrievalsystemen, EDV-Beratung, Innovationsberatung, Geschäftsführungsassistenz, Informationsvermittlung, Organisation, IuD-Vertrieb, Kommissarische Leitung der IuD-Weiterbildung, Dokumentation und Entwicklung von Dokumentationssystemen. 
ACADEMIC SUBJECT:

Information Science

COUNTRY:

Germany

CITY, INSTITUTION: $\quad$ Regensburg, Universität Regensburg (p. 44)

07 Magister Artium (MA); Promotion in linguistischer Informationswissenschaft

08 2. Ebene; Vollzeitstudium; Das Studienfach kann mit Wirtschaftsinformatik kombiniert werden.

10 Allgemeine Hochschulreife; sonst keine weiteren Zulassungsbedingungen.

11 Das Studium kann nur zum Wintersemester aufgenommen werden.

12 Das Ziel des Studiums ist der Erwerb des berufsqualifizierenden Abschlusses zum Linguistischen Informationswissenschaftler.

13 Das Studium ist in ein Grund- und ein Hauptstudium gegliedert

15 Praktika sind im Curriculum nicht vorgesehen, werden aber auf freiwilliger Basis empfohlen.

179 Semester

ACADEMIC SUBJECT:

COUNTRY:

CITY, INSTITUTION:
Information Science

Germany

Saarbrücken, Universität des Saarlandes (p. 44)

07 Magister Artium (MA); Doktor der Philosophie (Dr. phil., Promotion als 1. Studienabschluss und nach abgeschlossenem Hochschulstudium möglich) in Informationswissenschaft

08 2. und 3. Ebene; Vollzeitstudium; Haupt- oder Nebenfachstudium. Im Magister-Studiengang sind neben dem Hauptfach zwei Nebenfächer oder ein Nebenfach und drei Studieneinheiten zu wählen. Zunehmend werden auch Nebenfächer studiert, die nicht der Philosophischen Fakultät entstammen (z.B. Wirtschaftswissenschaft, Informatik). Umgekehrt kann Informationswissenschaft auch als Ergänzungsfach im Diplomstudium gewählt werden. Dies wird vor allem von Informatik-Studierenden genutzt.

09 Allgemeine Hochschulreife; für das Studium Informationswissenschaft besteht eine kapazitätsbedingte universitätsinterne Zulassungsbeschränkung (seit WS 92/93: 17 Neuaufnahmen pro Jahr im Hauptfachstudium). Die Zahl der Bewerbungen übersteigt die Zahl der Zulassungen regelmäßig bei weitem. 
10 Die Bewerbung erfolgt bei der Abteilung für studentische Angelegenheiten der Universität des Saarlandes, D-66041 Saarbrücken. Ende der Bewerbungsfrist ist der 15. Juli eines jeden Jahres.

11 Nur zum Wintersemester.

12 Informationswissenschaft nach dem "Saarbrücker Modell" stellt den (geglückten) Wissenstransfer in den Vordergrund. Demgemäß umfaßt das Studium vier Bereiche: Fachinformation und Dokumentation (vorwiegend Transfer von Fachwissen an Experten und interessierte Laien, u.a. unter Nutzung elektronischer Medien), Betriebliche Information und Kommunikation (Informationsmanagement in der Wirtschaft und in Behörden), Neue Medien;Publikumsinformation (Wissens- und Meinungstransfer an eine breite Öffentlichkeit), Informationsindustrie (Organisation, Methoden, Verfahrenstechnik und Ökonomie, Akzeptanz der Informationsvermittlung).

13 Das Studium ist in zwei Studienabschnitte zu je 4 Semestern (Regelstudium) untergliedert. Im 1. Studienabschnitt sind die Anforderungen an Haupt- und Nebenfachstudierende gleich. Nach dem 1. Studienabschnitt findet eine Zwischenprüfung statt. Der 2. Studienabschnitt ermöglicht im Rahmen der vier Bereiche das Setzen eigener vertiefender Schwerpunkte.

14 Die Veranstaltungen der Fachrichtung werden in einem vier- bzw. achtsemestrigen Zyklus angeboten. Die folgenden Veranstaltungstitel sind dabei grobe Schwerpunktangaben, die inhaltliche Ausprägung ist an den Entwicklungen bzw. auch an Fallstudien ausgerichtet. Über das garantierte Angebot des Veranstaltungszyklus hinaus bietet die Fachrichtung in der Regel zusätzliche Veranstaltungen an.

Erster Studienabschnitt: Proseminare können auch als Forschungsseminare angeboten werden, d.h. es werden Pro- und Hauptseminarscheine vergeben. VL Informationswissenschaft: Theoretische Grundlagen (Informationssysteme;Informationsrezeption) mit Proseminar zu Grundlagenfragen; VL Informationswissenschaftliche Methoden (Informations- und Systemananalyse (Benutzer-;Bedarfsanalyse) mit Proseminar zu Methoden; VL Grundlagen der Informations- und Dokumentationspraxis (Geschichte;Bausteine); (Die folgenden Vorlesungen jeweils mit einem Proseminar zu ausgewählten Themen:) VL Methoden und Verfahrensweisen praktischer Information und Dokumentation (Bibliotheken;Archive;Dokumentationsstellen); VL Grundlagen der Informationslinguistik; VL Grundlagen der Informationstechnologie (Informationsnetzwerke;Informationsbanken); VL Wissensrepräsentation; VL Soziale und psychische Faktoren der Information und Kommunikation. Zweiter Studienabschnitt: (jeweils mit Hauptseminar zu ausgewählten Themen): VL Informationsorganisation;-management; VL Fachinformation; VL Publikumsinformation; VL Informationsindustrie.

15 Praktika sind nicht verpflichtend, werden aber empfohlen. Es ist geplant, praktische Anteile in den Studiengang zu integrieren.

16 Am Ende des Grundstudiums ist die Zwischenprüfung im Haupt- und in den Nebenfächern, am Ende des Studiums die Magisterprüfung abzulegen. Die Magisterprüfung besteht aus der mündlichen und schriftlichen Prüfung im Hauptfach und in den Neben- 
fächern sowie der wissenschaftlichen Hausarbeit (Magisterarbeit), die innerhalb von sechs Monaten bearbeitet werden muß.

17 Die Regelstudienzeit beträgt 9 Semester (einschließlich Prüfungssemester).

18 Tätigkeitsfelder für ausgebildete Studenten sind Fachinformationseinrichtungen, größere Forschungseinrichtungen, Informationsvermittlungs- und Beratungsstellen, Informationseinrichtungen der Medien, Verlage, nationale und internationale Verbände. Hinzu kommt die Möglichkeit einer selbständigen Tätigkeit (z.B. Information broking).

! Bei Interesse am Studium der Informationswissenschaft wird angeraten, ein Beratungsgespräch mit dem Lehrstuhlinhaber, der Zentralen Studienberatung oder der Fachschaft zu vereinbaren! Eine Curriculumsrevision ist vorgesehen, bitte aktuellen Stand erfragen.

ACADEMIC SUBJECT:

COUNTRY:

CITY, INSTITUTION:
Information Science

The Netherlands

Amsterdam, Universiteit van Amsterdam (p. 52)

07 Masters Degree, Certificates in Book and Information Science

09 Secondary education, polytechnics.

10 First of December.

11 At start of each trimester. Preferably at start academic year.

12 Scientific education in the field of Information Management, especially documentary information.

13 Two graduation options: Book Science, Documentary Information Science.

14 After preliminary year (examination) 10 obliges, thesis, 6 moduls free to chose.

15 Pratical studies are intended.

16 At the end of each module and at the end of trimester.

17 Four years.

18 Graduates in all kinds of library/information functions. 


\begin{tabular}{lll} 
ACADEMIC SUBJECT: & \multicolumn{2}{l}{ Information Science } \\
COUNTRY: & Norway \\
CITY, INSTITUTION: & Oslo, Statens bibliotek- og informasjonshøgskole (p. 56)
\end{tabular}

07 Postgraduate in Information Science and Data Processing

09 To be accepted as student, one must have to be a generally well qualified librarian and have data processing, information retrieval and mathematics/statistics as major options in the 3 year undergraduate programme, or equivalent courses.

10 Observe the 15th of April as closing date for next years admission.

11 The studies are open to foreign students. The school can't offer support for living cost. The State Educational Loan Fund (P.B. 175, Økern, DK-0510 OSLO) may on certain conditions offer assistance to foreign students. All teaching takes place in Norwegian language. Students have to prove sufficent abilities to follow the programme.

12 The aim of the two year programme is to produce librarians with a sound competence in information handling, with special reference to automated methods, based on a thorough knowledge of administration, organization and retrieval of documents and data.

13 The scholastic year consists of 10-11 hours a scheduled student-lecturer contact hours a week, comprising traditional lectures, seminars, set questions and term paper discussions and a number of student organized sessions. In addition, individual non-scheduled tutorials are frequent.

14 Tool Studies/Introductory Courses, Programming, Database Management Theory, Information Retrieval, Information and Society, Advanced Seminar, Thesis, Project Work.

19 Two years

18 The candidates have left the school for a number of interesting and well payed jobs within the data processing industry (development of information retrieval and library software), library automation units, information units in oil industry, government offices and, of course, larger public and research libraries.

! Entrance without fee.

$\begin{array}{ll}\text { ACADEMIC SUBJECT: } & \text { Information Science } \\ \text { COUNTRY: } & \text { Poland } \\ \text { CITY, INSTITUTION: } & \text { Kraków, Uniwersytet Jagiellónski (p. 57) }\end{array}$

07 Diploma in Information Science 
11 Competitive examination is arranged on the beginning of July.

14 Theoretical and Methodological Problems of Librarianship and Information Science, Introduction to Computer Science, Information Systems, Database (Software) in Information Science and Libraries, The Use of Text Editors, Problems of Organization, Management and Marketing in Libraries and Publishing Houses, Setting Up One's Own Database.

16 To complete the postgraduate school students are required to pass one examination that covers courses no 2, 3 and 4; in addition each student has to set up his/her own database and demonstrate that he/she is able to work with a microcomputer.

171 year

! Participants of the Postgraduate School are charged a tuition fee.

ACADEMIC SUBJECT:

COUNTRY:

CITY, INSTITUTION:

\section{Information Science}

Spain

Barcelona, Universita Autònoma de Barcelona (p. 70)

07 Llicenciatura en Ciències de la Información

09 Condicions per a láccés a la Universitat per Facultas: Haver aprovato convalidat el COU i les Proves d'Aptitud per a l'accés a Facultas, Escoles Tècniques superiors o Col. legis Universitaris; Haver superat el COU abans del curs acadèmic 1974-1975; Haver superat les proves d'accés per a més grans de 25 anys al Centre respectiu (estan exempts de preinscripció); Estar en possessió del títol de Llicenciat de qualsevol Facultat o equivalent; Estar en possessió del títol de Diplomat d'Escola Universitària o equivalent.

10 Tant les persones admeses per primera vegada en un centre universitari com els estudiant dels altres cursos han de formalitzar la matrícula a 1 secretaria del centre corresponent $i$ durant els dies i mesos establerts amb aquesta finalitat.

11 Juliol; Alumnes més grans de 25 anys: Dia de juliol.

13 D'aquest només se'n faran quatre convocatòries d'examen en els dos cursos acadèmics següents. La inexistència de grups per a aquestes assignatures en extinció es suplirà amb tutories específiques.

14 Relació d'assignatures per cursos: Primer curs: obligatòries les assignatures: Introducció a la Communicació de Masses; Teoria i Estructura del Llenguatga (Llengua Catalana); Primer curs: assignatures optatives: Teoria i Estructura del Lenguatge (Llengua Castellana); Sociologia General; Història Universal Contemporània; Història del Pensament Politic i Social; Economia Politica.

Segon curs: obligatòries les assignatures: Teoria General de la Informació; Tecnologie de la Informació I; Mercadotècnica. Segon curs: assignatures optatives: Redacció Periodística I; Metodologia de les Ciències Sociales; Història d'Espanya Contemporània; Institucions 
Jurídico-Polítiques Contemporànies; Estructura Econòmica Mundial i d'Espanya; Documentació.

Tercer curs: obligatòries les assignatures: Història General de la Comunicació; Teoria i Tècnica de la Informació Audivisual I (Radio); Redacció Periodística II; Mètodes d'Investigació Motivacional. Tercer curs: assignatures optatives: Estructura social d'Espanya; Règim Polític Espanyol; Economia de la Informació; Literatura Espanyola; Moviments Artístics Contemporais; Opinió Pública; Literatura Catalana.

Quart curs: obligatòries les assignatures: Teoria i Tècnica de la Informació Audivisual II (TV). Quart curs: assignatures optatives (Secció Periodissme): Semiòtica de la Comunicació de Masses; Teoria i Anàlisi de la Televisió; Ràdio I (Mitjà d'Informació); Tecnologia de la Informació II (Premsa Escrita); Informació Periodística Especialitzada I; Teoria i Història del Cinema.

Cinqué curs: assignatures optatives (Secció Periodissme): Història de la Communicació Social a Espanya i Catalunya; Teoria de la Comunicació Social; Teoria, Història i Tècnica de la Image; Informació Periodística Especialitzada II; Rádia II (Mitjà d'Expressió); Dret de la Informació; Relacions Internationales; Televisió com a Mitjà d'Informació. Quart curs: assignatures optatives (Secció Publicitat): Estadística; Mitjans de Comunicació Publicitària; Creativitat Publicitària; Tecnologia dels Mitjans Audivisuals en Publicitat; Redacció Publicitària en Catalana; Semiòtica de la Comunicació de Masses.

Cinqué curs: assignatures optatives (Secció Publicitat): Empresa Publicitària i Dret de la Publicitat; Teoria i Tècnica de les Relacions Públiques; Marketing II; Teoria i Técnica de la Propaganda Política; Tecnologia dels Mitjans Impresos en Publicitat.

16 La matrícula dóna dret a dues convocatòries d'exàmens fínals, una al juny i una altra al septembre (Convocatòria ordinària).

17 Quart curs.

ACADEMIC SUBJECT: COUNTRY: CITY, INSTITUTION:

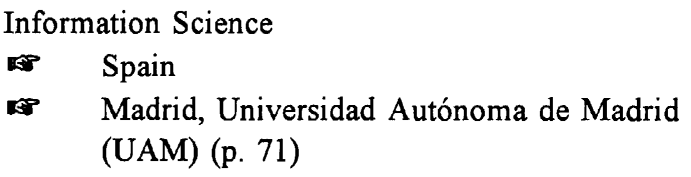

07 Doctor en Ciencias de la Documentación y la Información

08 tercer ciclo; Postgraduados; tiempo completo

09 Los estudiantes deben poseer un título de licenciado en alguna Universidad.

10 Comienza octubre de cada año académico.

11 Comienza octubre de cada año académico; los cursos empienzan en enero de cada año y terminan al final de marzo.

13 Se ofrecen cursos de Doctorado para cada disciplina que tienen carácter optativa. El estudio consiste en clases teóricas, seminarios, ejercicios prácticos y visitas profesionales. 
14 Fundamentos teóricos de la Información y de las Ciencias de la Documentación; Información como sistema; Sistemas de Información; Influencias sociales, económicas e industriales de la Información en la sociedad actual; Principios fundamentales de la automatización de la Información; Hardware, software y programas; Tratamiento de la Información; Lenguajes Terminológicos; Indización; Recuperación de la Información; Tesauros: construcción y uso; Bases de Datos; Construcción y uso de Bases de Datos; Utilización de ordenadores; Obtención de microfilms; Inteligencia Artificial; Sistemas Expertos; Hipermedia; Organización y gestión de servicios de Informción; Automatización de Bibliotecas.

15 Se realizan prácticas; las prácticas se pueden realizar en la Universidad o en alguna otra institución; existe la posibilidad de realizar prácticas en el extranjero.

16 Los exámenes pueden ser escritos u orales.

172 semestres

18 De momento no se tiene información sobre las posibilidades profesionales de los aprobados.

ACADEMIC SUBJECT:

COUNTRY:

CITY, INSTITUTION:

\author{
Information Science \\ United Kingdom \\ Glasgow, University of Strathclyde (p. 85)
}

07 Master of Science (MSc), Diploma in Information Science

08 2nd level; full-time

09 Bachelor

11 September

12 To create graduates capable of working in a wide range of information careers in the public and private sectors.

14 Information Resource Management; Information Networks; Communication of Information; Marketing of Information

15 Software applications packages for all courses for 3 weeks in Library or Information Services.

16 Examination in all classes, taken in May/June.

18 Range of professional information posts in public and private sectors. 
ACADEMIC SUBJECT: Information Science

COUNTRY:

United Kingdom

CITY, INSTITUTION: London, City University of London (p. 87)

07 Master of Science (MSc), Diploma in Information Science

08 2nd level; full-time, part-time

09 A good first degree.

11 October of each year.

12 Introduction of whole area of Information Science, specialization in chosen areas.

138 core modules, 2 core more elective modules, Dissertation

14 The core modules are: Information Industry and Information Resources; Computers and Communications Technology; Corporate Structures and Information Managment; Information Retrieval; Legal and Policy Aspects of Information Work; Research Methods

15 Practical work not during the course.

164 exam papers, 3 hours each

17 One year

18 Variety of work throughout information professions.

! Entrance with fees.

ACADEMIC SUBJECT: Information Science

COUNTRY: United Kingdom

CITY, INSTITUTION: $\quad$ London, University College of London (p. 88)

07 Master of Science (MSc) in Information Science: Computerized Systems for Librarians, Archivists and Informations Managers

08 2nd level; full-time; part-time

09 first degree + professional qualification + several years experience in information work

10 Deadline for enrolment is March 31st of each year.

11 Studies start October. 
12 The MSc is not intended as a first professional qualification but as a opportunity for established information professionals who wish to update their knowledge and gain practical experience of the new technologies.

13 The course is divided into three parts: Computer studies; applications of computers; project

14 Introduction to Computers; General Applications; Introduction to Programming; Management of Systems

15 Practical studies are intended.

16 The standard expected will depend on the individual piece of work.

17 For full-time students: one year; for part-time students two years

18 Continue in employment, perhaps with promotion

! EEC students may be eligible for funding under the ERASMUS scheme; further information may be obtained from the Registrar's Office, University College.

Composition fees due in any session become payable.

\author{
ACADEMIC SUBJECT: Information Studies \\ COUNTRY: Ireland \\ CITY, INSTITUTION: $\quad$ Dublin, University College of Dublin (UCD) (p.47)
}

07 Bachelor of Social Science (BSc) in Information Studies; at present the Degree of Bachelor of Social Science (BSocSci) may be conferred as a General Degree, an Honours degree or a Special Degree.

08 2nd level; full-time

09 Matriculation and Central Applications Office (Ireland)

11 Early October; early February on an exchange basis.

12 The Programme Students are able to develop some specialization in Information studies, which will enhance their preparation for careers in the information business or for further study within the information disciplines.

13 Students proceeding to the Degree of Bachelor of Social Science (General) must attend courses for three years and pass the following examinations: a) The First University Examination in Social Science (taken at the end of the First Year in three Subjects); b) The Second University Examination in Social Science (taken at the end of the Second Year) in two subjects; c) The Final University Examination for the Degree of Bachelor of Social Science (General) (taken in Summer at the end of the Third Year) in two 
subjects. The Degree of Bachelor of Social Science (General) may be awarded with Commendation in individual subjects provided a sufficiently high standard is reached.

14 First year: Sociology: Indroduction I+II, The Emergence of Sociological Perspectives I+II, The Methodology of Social Research I+II, The Social Structure of Ireland, Rural Sociology, Seminar, The Development of Social Policy in the 19th century, The Development of Social Policy in the 20th century, Indroduction to Social Policy: Theory and Concepts, Introduction to the Policy-making Process, Social Policy Research, Approaches to Social Issues, Irish Social Policy, Social Policy Seminar, Documentary Research, Workshop, Information and Society, Presentation of Information I, Literacy and Literature I, Organization of Information, second year: Information and Society, Presentation of Information I, General Information Resources, Studies in Literacy and Literature, Organization of Information, Indroduction to Computers, third year: Information in Organizations, Information Behaviour, Issues in Information Studies, Communication in Science and Technology, Presentation of Information II, History of Information Science, Business and Financial Information, Online Searching, Electronic Information Resources, European Information Market, Expert Systems, Subject Access to Information, Data Base Management Systems, Abstracting and Indexing, Microcomputers: Hard- and Software, Information Systems Analysis and Design

15 Practical studies are intended.

16 College and University exams at the end of each semester.

173 years

18 Personnel Manager; Information Scientist; Public Administration; Librarian

$\begin{array}{ll}\text { ACADEMIC SUBJECT: } & \text { Information Studies } \\ \text { COUNTRY: } & \text { Ireland } \\ \text { CITY, INSTITUTION: } & \text { Dublin, University College of Dublin (UCD) (p. 47) }\end{array}$

07 Master of Arts (MA) in Information Studies

08 2nd level; full-time

09 Candidates for the MA degree by thesis should normally a) have obtained at least Second Class Honours, Grade I in their primary degree examination, and if their primary degree is not in Information Studies, b) have attained at least Second Class Honours in the Diploma in Library and Information Studies of the University or its equivalent in another University. Candidates for the MA degree by examination should normally a) have obtained at least Second Class Honours, Grade II in their primary degree examination, and if their primary degree is not in Information Studies, b) have attained at least Second Class Honours in the Diploma in Library and Information Studies of the University or its equivalent in another University. 
11 Applications should be received by the Department on or before first May of the year in which the course begins. Selection will be by interview.

12 In this degree programme students are abel to develop their interests and skills to an advanced level in particular areas of study and to demonstrate their competence in a thesis on a theme relevant to their own careers and aptitudes.

14 Some of the following courses: Information and Society, Presentation of Information I-III, General Information Resources, Studies in Literacy and Literature I+II, Organization of Information, Introduction to Computers, Issues in Information Studies, Historical Bibliography, History of Information Science, Management of Information Agencies, Bibliographic Information Resources, Business and Financial Information, Online Searching, Electronic Information Resources, European Information Market, Literature for Children, Data Base Management Systems, Cataloguing Classification, Microcomputers: Hard- and Software, Information Storage Technology I, Information Policy, Information and Knowledge I, Rare Books Curatorship, Information Retrieval Theory, Electronic Library Systems, Research Methods

16 The MA degree may be taken by a major thesis (Mode A) or by examination and the presentation of a minor thesis (Mode B). All candidates will follow a course in research methods, and all candidates will attend research seminars as prescibed by the Department.

18 Students can expect to find careers in Information Analysis, Information Consultancy and Management, Librarianship, Information Science and Research. The Department's programmes are recognised by Irish and overseas professional associations.

ACADEMIC SUBJECT: COUNTRY: CITY, INSTITUTION:
Information Studies

United Kingdom

London, University of North London, School ... (p. 90)

07 Postgraduate Diploma, Master of Arts (MA) in Information Studies

08 2nd level; full-time, part-time, mixed-mode

092 A-Levels or equivalent. Non standard mature entrants also considered.

11 Mid September normally-mid February in special circumstances.

Intending students are advised to apply as early as possible as the number of full-time candidates that can be considered for bursaries is limited, and as the part-time course usually becomes full very quickly. Selection of applicants will be made from information provided on application forms and references, and, in most cases, by interview. Places on the course are limited, and technical eligibility is not in itself guarantee of acceptance. Information given on application forms must be correct and complete. We reserve the right to withdraw offers to places made on the basis of false or misleading information. Degree certificants or other evidence of examination results must be produced on request. 
Applicants may be required to furnish evidence of knowledge of and competence in the English language at the time of application or at a later date. The University cannot refund expenses incurred in travel to and from interview.

12 The School of Information Studies has, for over twenty years, offered postgraduate courses which have been characterised by a strong emphasis on assessment by coursework and a wide choice of options. This revised course offers postgraduate Diploma and MA components, enabling students to aquire knowledge, skills and other qualities appropriate for understanding and contributing to the development of information services. It places emphasis on Library and Information Service, on Information Technologies and on Mass Communications, and provides an intellectual underpinning for professional practice in a variety of information service contexts. It has been designed to be accessible both to full-time and part-time students.

14 Compulsory modules: Information and Society, Information Systems and their Users, Information Retrieval Systems: Design and Implementation, Essentials of Management. These options relate to the core course: Information and Society. International Information and Communications, Publishing, Bookselling and Reading, Information and Communication in Scientific Communities, Information Services and Ethnic Minorities, Information for Local History. These options relate to the core course: Information Systems and their Users: Bibliographic Systems and Sources, Subject Studies, Business Information and its Sources, Audio Visual Media, Customising Database Software, Intelligent Information Systems. These options relate to the core course: Information Retrieval Systems: Organizing Bibliographic Information: Standard Systems and Processes, Inhouse Computer-based Retrieval Systems, Information Software, Online Information Systems. These options relate to the core course: Essentials of Management, Information Services to Industrial, Commercial and Governmental Organizations, Information Services to Further and Higher Education, Information Services to Local Communities, Information Systems Analysis

15 Full-time students undertake a four week practical placement split equally between the end of the first semester and the beginning of the second semester. The placement is arranged by the School. Part-time students without appropriate experience may be required to undertake placement; practical studies can be carried out by various worker projects, group work, practical placements, computer-based-projects; we have exchange agreements with same institutions and are exploring links with more in Europe and the USA.

16 All modules are of equal weight and are separately assessed. Compulsory modules are assessed by a) an essay of 2.000 words or equivalent and b) a three-hour written examination paper. Optional modules are assessed by an essay of 4.000 words or equivalent. The MA component of the course is assessed by a) satisfactory attendance at tutorials and research seminars and b) a Masters project of 12.000-15.000 words.

173 years full-time, 6 years part-time for undergraduates; 1 year full-time, 2 years part-time for postgraduates 
18 The diploma course is designed as an intellectual and practical preparation for employment at professional level in information work of all kinds, library and non-library based. The course has been approved as meeting the professional and educational requirements of Library Association and the Institute of Information Scientists. Both have agreed to grant exemption from certain of their admission requirements. The MA course, as well as introducing students to independent research, is a suitable preparation for senior posts in information work.

! Fees 1991-1992: PG Diploma element full-time £ 1100.00 (Oct-June); PG Diploma element part-time $£ 400.00$ p.a. (Oct-June); MA element full-time $£ 400.00$ (July -Oct); MA element part-time $£ 400.00$ (Oct-July)

ACADEMIC SUBJECT:

Information Studies

COUNTRY:

United Kingdom

CITY, INSTITUTION: Loughborough, Loughborough University of Technology (p. 90)

07 Master of Arts (MA), Master of Science (MSc), Diploma of Loughborough University of Technology (DLUT) in Information Studies

08 2nd level; full-time, part-time

09 Applicants should have a good honours degree and about one year's experience (six week's minimum in exceptional circumstances), which can encompass a whole range of library or information-related jobs.

11 In October of each year.

12 The programme aims to equip students with an understanding of information, from its origination, communication, storage and retrieval through to its use. It has a vocational orientation in order to prepare graduates from a wide range of disciplines for a career in information work.

14 Information Management, Information Sources, Use and Searching, Information Technology, Information Handling, Database Structure and Design. optional modules: Business Information, Health and Welfare Information Management, Human Factors in Information Systems Design, Legal and Professional Issues, Mass Media and Audio-visual Communication, Records Management

16 Assessment for the MA or MSc degrees is by course-work and dissertation; for the DLUT by course-work and project report.

171 year full-time or 3 years part-time 
18 Many former graduates are now employed in information services-in business, industry, the professions and in the public sector. Other have gone into jobs in information systems design and development, and into consultancy.

$\begin{array}{lll}\text { ACADEMIC SUBJECT: } & \text { Information Systems } \\ \text { COUNTRY: } & \text { Poland } \\ \text { CITY, INSTITUTION: } & \text { Wrocław, Politechnika Wrocławska (p. 61) }\end{array}$

07 Master of Science (MSc) in Information Systems

08 2nd level; full-time

09 Good secondary school certificate; most foreign students have to take 1 year of Polish before the begin of studies.

10 Application for admission sent to Polish embassy or the University President

11 In the beginning of October.

12 The graduate of the Scientific Technical Information Systems Institute is a specialist in programming, organization and exploitation of computer information retrieval systems of any scale and subject, especially scientific-technical informations systems in any computer environment.

14 General computer education is realized on the two first years of studies. It contains Fundamentals of Electronics, Information Theory, Architecture of Computers and Specialistic Equipment Used in Information Systems and Knowledge of Methodology and practice of Programming. The programme of education in the later years of studies contains subjects from the range of the Theory of Information Retrieval, Information Retrieval Languages, Data Bases Technology, Fundamentals of Network Systems, Artificial Intelligence and Methodology of Information Systems Design.

15 It is possible to organize practical studies for students.

16 Students have to pass an exam in order to complete obligatory courses.

175 years

18 Programmers and system managers in banks, computer Software Companies, Computerized Libraries and Universities. 
ACADEMIC SUBJECT: COUNTRY:

CITY, INSTITUTION:

\author{
Information Systems \\ United Kingdom \\ Brighton, University of Brighton (p. 83)
}

07 Master of Science (MSc), Postgraduate Diploma in Information Systems

08 2nd level; full-time

09 A degree of class 2 or better or equivalent professional classification or equivalent overseas degree plus very limited computing experience.

10 When the course is full-normally April/May for September entry; 35 students can start studies each term.

11 Late September of each year.

12 To take students with little, or no, knowledge of information technology and to equip them with the necessary skills and knowledge for a demanding carrier in an information technology related field.

13 Students join the course at the start of the autumn term and the final Examination Board is in November of the following year. The first twelve week term, Foundation Studies, provides students with a basic grounding in computer related topics. The next one and a half terms, Application Studies, develop the skills of putting the theory into practice. Four subjects are taught during Foundation and Application Studies. They are two weeks duration in Foundation Studies and three weeks in Application Studies. One further assignment is set to be researched in the Spring term and handed in immediately after Easter. The second half of the summer term is concerned with assessment. The dissertation assessment involves every student presenting their own dissertation and assessing a number of their peer's dissertations.

14 System Analysis and Design; Application Building; Management in Information Systems; Technology; Dissertation; Project; Coursework

15 Practical studies are intended in the fourth term project.

16 Application Studies assessment will consist of three examinations, coursework and a dissertation. The three papers will be: a) a Problem Paper-drawing on the skills from all areas; b) a Case Study Paper-based upon the final term extended case study; c) a Technical Paper-based upon the final term extended case study.

17 The MSc runs for 53 weeks (= four terms).

! Students who have completed three years' ordinary residence within the EC will be assessed at the EC rate for fees purposes. 


$\begin{array}{lll}\text { ACADEMIC SUBJECT: } & \text { Library and Information } \\ \text { COUNTRY: } & \text { Germany } \\ \text { CITY, INSTITUTION: } & \text { Hamburg, Fachhochschule Hamburg (p. 37) }\end{array}$

07 Diplombibliothekar im Studiengang Bibliothek und Information

08 1. Ebene; Vollzeitstudium

09 Allgemeine Hochschulreife/Fachhochschulreife oder gleichwertig anerkannte Vorbildung. Die Zulassung ist beschränkt (145 pro Jahr)

11 Zum jeweiligen Semesterbeginn.

12 Diplombibliothekare arbeiten in öffentlichen Bibliotheken von Städten und Gemeinden. Sie leisten einen wesentlichen Beitrag zur Kulturarbeit durch qualifizierte und sachgerechte Beschaffung, Präsentation und Vermittlung von Medien für alle Bevölkerungsgruppen und deren unterschiedliche Informations-, Bildungs- und Unterhaltungsbedürfnisse. In wissenschaftlichen Universal- bzw. Spezialbibliotheken sowie in Einrichtungen aus den Bereichen Information und Dokumentation sind Diplombibliothekare Fachleute für Informationsvermittlung. Sie unterstützen wissenschaftlich und berufspraktisch Arbeitende bei der Suche nach Information und bei deren Beschaffung. Beide Berufsgruppen nutzen zunehmend neue Informationstechnologien wie CD-ROM und Datenbanksysteme.

13 Das Studium gliedert sich in ein dreisemestriges Grundstudium, ein Praxissemester in einer dem Studienschwerpunkt ÖB oder WB entsprechenden Bibliothek oder Informationseinrichtung und ein dreisemestriges Hauptstudium.

14 Inhaltliche und formale Erschließung von Medien, Bibliotheksbetriebslehre, Anwendung von EDV und AV Medien, Bestandsaufbau und -vermittlung, Publikations- und Medienkunde, Bibliographien und Auskunftsdienst, Statistik, Öffentlichkeitsarbeit, Benutzerforschung, Bibliotheksgeschichte

15 Praktika sind vorgesehen; das Hauptpraktikum dauert längstens 6 Monate und ist in einer Bibliothek/Informationseinrichtung gemäß dem gewählten Studienschwerpunkt (ÖB oder WB) in der Regel zwischen dem 3. und 4. Semester abzuleisten. Im ersten und 2. Semester finden sog. Praxistage in öffentlichen und wissenschaftlichen Bibliotheken statt.

16 Das Grundstudium wird mit einer Zwischenprüfung, das Hauptstudium mit der staatlichen Diplomprüfung abgeschlossen.

17 Regelstudienzeit: 6 Semester und 2 Monate; durchschnittl. Studiendauer: 7,4 Semester

18 Die Tätigkeitsfelder für Bibliothekare sind überwiegend Bibliotheken, seltener auch Dokumentationseinrichtungen und Informationsvermittlungsstellen. Die meisten Abgänger arbeiten als Angestellte, aber auch als Beamte oder Selbständige. In Schule, Hochschulen und öffentlichen Dienst sind knapp die Hälfte, in den Bereichen Kunst, Theater, Film und Funk, Verlags- und Pressewesen etwa ein Drittel aller Absolventen beschäftigt. 
ACADEMIC SUBJECT:

COUNTRY:

CITY, INSTITUTION:
Library and Information Science

Austria

Wien, Österreichische Nationalbibliothek (p. 2)

07 Grundausbildungslehrgänge Bibliotheks-, Dokumentations- und Informationsdienst für die Verwendungsgruppe A-Akademiker

08 3. Ebene; Vollzeitstudium

09 Abgeschlossenes Hochschulstudium und die Beherrschung von Englisch und zwei weiteren Fremdsprachen

10 Die Bewerbungsfrist wird durch Veröffentlichung im Amtsblatt der Wiener Zeitung bekannt gemacht.

11 Der Kursbeginn wird durch Veröffentlichung in der Wiener Zeitung bekannt gemacht. Interessenten werden vorher informiert.

12 Es soll ein Überblick über den praktischen Ablauf des Bibliotheksbetriebes, sowie Kenntnisse der formalen und inhaltlichen Erschließung, Informationsbeschaffung und -vermittlung sowie ein Überblick über die Theorie des Bibliotheks-, Dokumentations- und Informationswesens gegeben werden.

13 Der Kurs teilt sich in 3 Lehrgangsteile: der erste und sogenannte dezentrale Teil findet an verschiedenen Ausbildungsbibliotheken statt, der sogenannte Teil "praktische Verwendung" findet an verschiedenen Bibliotheken und Dokumentationsstellen statt, der zweite und sogenannte zentrale Teil findet an der Österreichischen Nationalbibliothek statt.

14 Rechtskunde; Entwicklung und Aufgaben, Organisation und Betrieb von Bibliotheken und Dokumentationsstellen; Dokumentenkunde, Dokumenterschließung, Informationsbeschaffung und -vermittlung (einschließlich Benutzerschulung und Öffentlichkeitsarbeit)

15 Praktika sind vorgesehen; die Möglichkeit von Auslandspraktika ist grundsätzlich gegeben.

16 Der Kurs endet mit der Anfertigung einer schriftlichen Hausarbeit.

172 Jahre

18 Bibliothekare, Dokumentare und Informationsfachleute

! Diese berufsbegleitende Ausbildung wird im Rahmen der österreichischen Beamtenausbildung absolviert. - Eine grundlegende Reform der Ausbildung ist in Vorbereitung. 


$\begin{array}{ll}\text { ACADEMIC SUBJECT: } & \text { Library and Information Science } \\ \text { COUNTRY: } & \text { Belgium } \\ \text { CITY, INSTITUTION: } & \text { Antwerp, Universiteit Antwerp (p. 3) }\end{array}$

07 Information professionals in Library and Documentation (postgraduate degree).

09 University graduates from all disciplines and graduates from institutes of higher education receive a diploma at postgraduate level.

10 The registration period runs from July first to October 11 th.

11 October at all uneven 4 years.

12 Education for Information professionals in Library and Documentation.

13 The programme consists of 7 parts spread over two academic years A and B, with a total of 600 college hours (excluding practical training and thesis).

14 Basic subjects: Formal Logic, Introduction to Linguistics, Organization Management, Social and Legal Aspects of Information, Data Communication, Instrumentarium, Introduction to Data Processing (Information Science), Data Processing: Applications and Practical, Mathematical and Statistical Methods, General Introduction to Information Management, Documentary Information Management, Documentary Information Systems, The Documentary Information Market, Book and Library Science, Knowledge Representation, Administrative Information Management, Electronic Document Processing, Subsidary Subjects, Practical Training, Thesis.

15 Practical studies are intended, integrated in curriculum; practical studies can be carried out by a practical seminars, internships and projects; practical studies in foreign countries are possible with the ERASMUS-Programme.

16 Each Semester for all courses given.

172 years part-time

18 Librarians and Documentalists, both in Public Service and Private Enterprises

! The registration fee for the first year is currently $15.500 \mathrm{BF}$ (enrolment, registration, and examination fees). The second year students have to enrol again but only pay an enrolment fee. Students wishing to enrol for a third year-to finish their thesis for example -pay $1.500 \mathrm{BF}$. The registration fee is established every academic year by Governing Body. 
ACADEMIC SUBJECT:

Library and Information Science

COUNTRY:

as Denmark

CITY, INSTITUTION:

Københaven, Danmarks Biblioteksskole (p. 7)

07 Master in Library and Information Science (MLISc)

08 2nd level; full-time, part-time

09 Students accepted for each programme: 30.

11 Course begins in Fall.

12 The goal of the curriculum is to give the student capabilities and competencies in: a) Information Need Assessment, b) Analysing Organizations Needs for Information Strategies and Information Managment, c) Implementation of Information Strategies, d) different aspects of Information Management, e) psychological and linguistic elements of Information Retrieval, f) use of Information Technologies, g) advanced Information Retrieval, h) Implementation, Design, and Management of Information Systems, i) Evaluation of Systems, j) Research Qualifications.

14 Information Science as a Discipline; Information Retrieval Theory; Information Management/Information Economics; Design; Indexing; Retrieval Systems; Value-added Information; Interface-problems.

15 No Practical Training is intended.

172 years (full-time), 4 years (part-time)

! There is no tuition fee at Danish universities and colleges.

ACADEMIC SUBJECT:

COUNTRY:

CITY, INSTITUTION:
Library and Information Science

Estonia

Tallinn, Tallinn Pedagogical University (p. 8)

07 University Diploma, Masters degree, Doctors degree in Librarianship and Information Science

09 To pass entrance examinations there is an Estonia language test at the beginning of July.

11 First September of each year.

12 To educate professionals for various sectors of Library and Information Services: for academic libraries, for public libraries, for children's and school libraries, for higher school and research libraries, for information centres, archives, museums, publishing 
houses, commercial and industrial companies, book restoration and conservation centres where knowledge of methods and mediums or document handling, unsorting, mediating, searching and analysing are needed.

13 The study programme includes general and special courses of 160 studyweek duration.

14 I. lower stage: general courses: Estonian History; Philosophy; Management; Estonian; Foreign Languages; Logic; Research Methods; Sociology; Social Psychology. general courses of the speciality: History of Culture; Scientology; Literature; Rhetoric and Elocution; Computer Studies. Ccourses of the speciality: Fundamentals of Librarianship; Information Sources; Fundamentals of Information Science; Cataloguing; Information Retrieval Languages; Technology of Libraries; History of Book; Bibliography; Information Services; Library and Information Services; Organization of Library Work; Subject Bibliography. II. higher stage: general courses: Estonian; Research Methods; Andragogic; Aestetics; Estonian Culture Sociology; deep-courses of speciality: Management of Library Work; Computer-based Information Systems; Organization and Arrangement of Publishing Activity; Subject Bibliography; Comparative Librarianship; Lectology; Social Psychological Problems of the Information Process; Contemporary Problems of the Speciality.

15 Practical studies are intended (altogether 23 studyweek).

16 The lower stage ends with a level examination of the Librarianship and Bibliography. The higher stage ends with the final examinations and diploma work. The coursework is guarded in the second, third and fourth year.

17 University diploma: 3 year basic level, 5 years $(3+2)$; master's degree: 1-2 years; Doctor's degree $1-4$ years

18 All kinds of libraries, information companies, book restoration and conservation centres.

! Entrance without fees.

\begin{tabular}{ll} 
ACADEMIC SUBJECT: & \multicolumn{2}{l}{ Library and Information Science } \\
COUNTRY: & Finland \\
CITY, INSTITUTION: & Abo/Turku, Abo Akademi University (p. 8)
\end{tabular}

07 Masters Degree, Licentiate, Doctorate in Library and Information Science

08 2nd and 3rd level; full-time

09 There are a number of basic qualifications which the applicant should have in order to be eligible for admission to Åbo. The following list specifies the requirements for students from Europe and the GUS: Baccalauréat (France), Abitur (Germany), General Certificate of education with at least two good A-level passes and three O-level passes (Great 
Britain), Bachillerato Unificado y Polivalente (BUP) plus Curs ode Orientacion University (COU) (Spain).

11 September (and January for postgraduate students)

12 Students are educated to hold posts in public, academic, and research libraries or information centres in both public and private sector and to do research, development and planing tasks in the field.

13 The courses taken for a basic degree are structured according to study programmes, and comprise courses in one main and in one or two subsidiary subjects. The total of 160 "study weeks" of credit required for the masters degree is divided into three different stages: a) General studies, b) Subject Studies, and c) Advanced Specialized Studies.

14 General studies: Introductory courses in the following subjects are compulsory to everyone studying: Library and Information Science, Accounting, Statistics, subject studies: Introduction to Library and Information Science, Field Work, Information Storage, Special Services, Use and Production of Material, Advanced Studies: Research: Theory and Methods, Libraries, the World of Science and Cultural Life, Seminars, Pro Gradu Thesis

15 Practical studies are intended; practical studies can be carried out by 12 weeks of field work (compulsory or a field work programme at an academic, a special or a public library or info centre + report).

16 Most courses have exams; Exams are usually taken at the end of the semester.

$17 \quad 5-6$ years

18 Librarians, information specialists, positions in government agencies

$\begin{array}{ll}\text { ACADEMIC SUBJECT: } & \text { Library and Information Science } \\ \text { COUNTRY: } & \text { Finland } \\ \text { CITY, INSTITUTION: } & \text { Tampere, Tampereen Yliopisto (p. 10) }\end{array}$

07 Master of Social Science (MSc); Licentiate of Social Science; Doctor of Social Science in Library and Information Science

08 2nd and 3rd level

09 If you have not yet attended any university: an official school-leaving certificate or transcript of secondary school record and official certificate giving evidence of your admission to a university of internationally recognized academic standing. This document must be signed by the appropriate university official and must specify the subject you are accepted to study. If you have attended a university: an official transcript of your university records. In all cases you need a certificate language test (e.g., TOEFL). Documents 
can be submitted in either Finnish, Swedish or English. - There is no fixed quotum for international students at the University of Tampere.

10 Application must have recieved by March 2nd of each year.

12 The Department educates professionals for service, administrative and planning purposes in the whole sector of library and information service. However, libraries and various information services form just one of the fields where the knowledge developed by information studies applies.

14 Foundations of Library and Information Science; Information Storage and Retrieval; Practical Work; Specializing Courses; Scientific Methods; Research in Information Storage and Retrieval; Research on Information Needs and Seeking; Reception of Culture; Research on Library and Information Service Institutions; Research on Publishing and Library Collections; Research Oriented Studies; Researchg Project and Masters's Thesis

15 Three months practical work are intended.

16 Written exam after every course and master's thesis.

176 years of study.

18 Librarians, Information Specialists, Information Managers

! The language of instruction is Finnish and English.

Please note that if you are accepted you will required to produce a financial statement that you have at your disposal at least FIM 20.000 when you apply for a residence from your local Finnish Embassy or Consulate.

ACADEMIC SUBJECT:

COUNTRY:

CITY, INSTITUTION:

\author{
Library and Information Science \\ Hungary \\ Budapest, Eötvös Loránd Tudományegyetem (p. 46)
}

07 Bachelor of Arts (BA); Master of Arts (MA); Doktor of Philosophy (PhD) in Library and Information Study

08 2nd and 3rd level; Library and Information Studies are possible to combine with all subjects teached on the Philological Faculty and the Faculty of Science.

09 Matriculation and entrance examination; there is a limitation concerning admission; 25-30 students can start studies each term.

10 The first March in each year.

11 October of each year. 
12 To educate first of all librarians and information specialists (for different types of libraries and other cultural, financial and other institutions).

13 Bachelor: 1. term: Fundamentals; 2.-4. term: Historical Subjects, Librarianship, Library Administration and Management; 5.-8. term: Information, Bibliography and Documentation, Information and Computer Studies

Master: 1.-4. term: Special studies according to choosing: A) Library Administration and Management, B) Information and Documentation, C) Library History and Museology

14 Fundamentals of Communication of Library and Information Science, History of Books and Libraries, Librarianship and Library Administration, Library Management, Information Science in each term. Lectures (60\%), Seminars (20\%) and Practicum (20\%).

15 The first rigorosum in vacation (200 hours in a public library) and in the 7 . or 8 . term 200 hours in a special library. Pratical studies in a foreign country is possible.

16 In each term about 3-4 oral examinations, in the end of 4th term the first rigorosum and the end of 8 . term the second rigorosum and state examen.

$17 \mathrm{BA}=4$ years $(8$ terms $) ; \mathrm{MA}=6$ years (12 terms); average duration of studies is $8-10$ terms.

18 Librarian, information specialist and editor

\author{
ACADEMIC SUBJECT: Library and Information Science \\ COUNTRY \\ $\infty$ Ireland \\ CITY, INSTITUTION: Dublin, University College of Dublin (UCD) (p. 47)
}

07 Diploma of Library and Information Studies (DLIS)

09 Candidates who hold a recognised university degree will be considered for admission to the Diploma in Library and Information Studies. Experience of information or library work is considered an advantage

11 Applications should be made to the Department before April 30th of the year in which the course begins. Selection will be by interview.

12 The graduate diploma prepares students for professional careers in information or library work.

14 The following course units are compulsory: Information and Society; General Information Resources; Organization of Information and some of the following courses: Information and Society; Presentation of Information I+II; General Information Resources; Studies in Literacy and Literature I+II; Organization of Information; Introduction to Computers; Issues in Information Studies; Historical Bibliography; History of Information Science; Management of Information Agencies; Bibliographic Information Resources; Business and 
Financial Information; Online Searching; Electronic Information Resources; European Information Market; Literature for Children; Data Base Management Systems; Cataloguing; Classification; Microcomputers: Hard- and Software; Information Storage Technologie I; Information Policy; Information and Knowledge I; Rare Books Curatorship; Information Retrieval Theory; Electronic Library Systems; Research Methods.

17 The normal duration of the course is one academic year of full-time study (Oct-June).

18 Students can expect to find careers in Information Analysis, Information Consultancy and Management, Librarianship, Information Science and Research. The Department's programmes are recognised by Irish and overseas professional associations.

ACADEMIC SUBJECT: Library and Information Science

COUNTRY:

Latvia

CITY, INSTITUTION: Riga, Latvijas Universitate (p. 49)

07 Bachelor of Arts (BA), Master of Arts (MA) in Library and Information Studies; Diploma in Librarianship

09 An applicant should have a certificate of secondary education as well as pass exams before entering the University. There is a limited number (50) of places admission.

10 First of July of each year.

11 First September of each year.

12 To give a broad professional education, and training in basic professional skills, which will enable the student to be employed in all library professions. To initiate the student in the theory and practice of Library and Information Studies Research.

13 Studies include lectures, small group discussions and practical activities. One term is about 5-6 courses (basic and option). Four basic subjects and two option subject per term. Eight terms for BA and four terms for MA.

15 Practical studies are intended.

16 Exams in basic courses in January and June.

174 years (8 terms) for BA and 2 years (4 terms) for MA.

18 It is possible for our students to get jobs in libraries, information centres, archives and museums. 


$\begin{array}{ll}\text { ACADEMIC SUBJECT: } & \text { Library and Information Science } \\ \text { COUNTRY: } & \text { Lithuanian } \\ \text { CITY, INSTITUTION: } & \text { Vilnius, University of Vilnius (p. 50) }\end{array}$

07 Bachelor of Arts (BA), Master of Arts (MA) in Library and Information Science

09 College certificate or any university course

11 First September of each year.

12 Training librarians and information managers

132 years of academic studies of LIS and general courses plus 2 years for Bachelor of Librarianship or of Information Science plus 2 years for Master of Library Science 2 years for Master's degree after any other university course (optional).

14 Library Science, Bibliography, Book Science, Information Science, Information Retrieval

15 Practical studies are intended in laboratories, libraries and information services-there are possibilities to have practical studies in foreign countries.

163 entering exams, 23 semester exams and 2 graduate exams

17 Bachelor's degree (4 years) and/or Master's degree (2 years) or 6 years

18 librarians, information managers

\author{
ACADEMIC SUBJECT: Library and Information Science \\ COUNTRY: \\ The Netherlands \\ CITY, INSTITUTION: Amsterdam, Hogeschool van Amsterdam (p. 51)
}

07 Bachelor in Library and Information Science (Hogere beroepsopleiding voor bibliotheek en documentaire informatie)

$08 \quad 1$ st level

09 To qualify for admission to Hoger Beroepsonderwijs (HBO) in the Netherlands, students must have a diploma from one of several types of secondary-schools: "VWO" diploma (pre-university education: 6 years after 6 years of primary education), or the "HAVO" diploma (general secondary education, higher level: 5 years after 6 years of primary education), or an appropriate "MBO" diploma (secondary vocational education, intermediate level: 3 or 4 years after 6 years of primary education). Applicants over the age of 21 who do not possess one of the above diplomas may be granted admission on the 
basis of other evidence which proves that they have the background knowledge necessary for HBO study ("21 + entrance examination").

12 Training for professional functions in all types of libraries and documentation centres. These institutes have in common that they establish, arrange and manage information collections to serve their users.

13 There are two types or regular higher education in the Netherlands: university education, and HBO or higher professional education. HBO institutes prepare students for particular professions and occupations, and tend to be more practically oriented than universities, where the emphasis is on theory and the generation of knowledge through research. A full time HBO study programme has a formal course lenghth of four years, and students are allowed a maximum of six years to finish. Usually, at the end of the first year, students must take a preliminary examination ("propaedeuse"). The next three years are in most cases divided into a main part ("Hoofdfase"-2nd, 4th year) and an internship, or period of supervised work-study ("stage") which take up most of 3 rd year.

14 General Theory of Information Handling, Communication, Storage and Information Retrieval, Management, Orientation Areas in Knowledge and Society; additional courses: Aspects of New Media, Theory and Practice of Archives, Theory and Practice of Music Libraries, Theory and Practice of Children's Libraries and of School Media Centres; graduate subjects: Information Transfer and Services, Information Retrieval Systems and Technology, Administration and Information Management.

15 Practical studies are intended; practical studies can be carried out through working visits, excursions, guest speakers, a short practical training period in the first year (6 weeks) and a practical training period in the third year (12 weeks).

16 Exams are at the end of each period. The final year is concluded with a graduation project (thesis).

174 years

18 Professional functions (including management functions) in all types of libraries and information centres.

\author{
ACADEMIC SUBJECT: Library and Information Science \\ COUNTRY: \\ The Netherlands \\ CITY, INSTITUTION: \\ Maastricht, Rijkshogeschool Maastricht (p. 54)
}

07 Hoger Beroepsonderwijs (HBO) in Library and Information Science

08 1st level; full-time

09 To qualify for admission to Hoger Beroepsonderwijs (HBO) in the Netherlands, students must have a diploma from one of several types of secondary-schools: "VWO" diploma 
(pre-university education: 6 years after 6 years of primary education), or the "HAVO" diploma (general secondary education, higher level: 5 years after 6 years of primary education), or an appropriate "MBO" diploma (secondary vocational education, intermediate level: 3 or 4 years after 6 years of primary education). Applicants over the age of 21 who do not possess one of the above diplomas may be granted admission on the basis of other evidence which proves that they have the background knowledge necessary for HBO study ("21 + entrance examination").

11 September of each year.

12 Educating students for functions in Libraries and Information Centres.

14 The following modules are taught: Introduction in Library and Information Science, Introduction Information Processes, Information and Society, Institutions in the Field of Information Science, Management I-III, Userstudies, Classification and Cataloguing, European Market, Document Managment, Thesauri, Collections, Information Processes, Marketing, Public Relations

15 Practical studies are intended; practical studies can be carried out in a broad variety of organizations; practical studies can be possible in USA, UK, Germany and Belgium.

16 By the end of each module; several exams have to be passed.

174 years

18 A wide variety of jobs in the information field (Librarian, Documentalist, Information Manager, System Analyst, etc.).

$\begin{array}{ll}\text { ACADEMIC SUBJECT: } & \text { Library and Information Science } \\ \text { COUNTRY: } & \text { Poland } \\ \text { CITY, INSTITUTION: } & \text { Kraków, Uniwersytet Jagiellónski (p. 57) }\end{array}$

07 Masters Degree in Library and Information Science

08 2nd level; full-time; extra-mural

09 Mature Examination and competitive examination in University

11 Competitive examination is arranged on the beginning of July.

14 Basic Course of Librarianship and Information Science; New Trends in Librarianship and Information Science; Books; Libraries and Information Science in the Culture; Printing and Bookselling; Documents and Information Management; Information Sources; Reading and Readers; Introduction to Computer Science; History of Science; Polish Literature; World Literature; Russian; A second foreign language (English; German; French; Spanish, etc.); Latin; Philosophy, etc. 
15 In the time of 5 years study for day students there are 3 practical studies in libraries or information centres organized; mainly in the summer vacation but sometimes in the academic year; we have not many possibilities to have practical studies in foreign countries because of financial problems but we tried to do and we will try to do this form of practices.

16 Competitive exam before the study and ca. 20 exams including the final masters examination.

175 years full study for day-students; 5 years full-studies for extra-mural students

18 Mainly our students are librarians or information officers, but they are also teachers in primary schools or sometimes they are officers in administration.

! The same curriculum is set for extra-mural students. The number of classes that they have to attend is however, reduced to 1-2 of the hours planned for full-time students. The difference is to be made up by reading and individual work. In the course of his/her fiveyear studies the student has to pass 20 examinations, including the final master examination. In order to take the final examination the student has to submit his/her master thesis. - Students have to pay full tuition.

ACADEMIC SUBJECT: COUNTRY: CITY, INSTITUTION:

\author{
Library and Information Science \\ Poland \\ Kraków, Wyższa Szkoła Pedagogiczna im. KEN \\ (p. 58)
}

07 Dyplom Magistra Bibliotekoznawstwa i Informacji Naukowej

09 Kryteria przyjęcia: świadectwo maturalne, rozmowa kwalifikacyjna, wyniki nauczania (oceny) ze świadectwa maturalnego. Studia podyplomowe: dyplom wyższej uczelni, podanie i ewentualnie inne dokumenty.

10 Oddawanie dokumentacji na studia stacjonarne do 9 czerwca. Limit przyjęć wynosi od 30 do 45 osób.

11 Studia stacjonarne: 1 październik; Studia zaoczne: połowa lipca.

12 Uzyskanie komptencji fachowych do pracy w bibliotekach różnego typu.

13 Studia podzielone są z regóły na roczne kursy. Każdy rok dzieli się na semestr zimowy i letni.

14 Każdego roku publikuje się nowy informator przedmiotów studiów.

15 Praktyki są przewidziane tylko na studiach stacjonarnych i zaocznych. 
16 Większość kursów kończy się egzaminem (ok. 20).

175 lat

18 Bibliotekarz, dokumentalista $w$ centrach informacji naukowej, redaktor $w$ wydawnictwach naukowych.

! Od 1993;94 możliwość uzyskania tytułu licencjanta po 3 roku.

\author{
ACADEMIC SUBJECT: Library and Information Science \\ COUNTRY: Poland \\ CITY, INSTITUTION: Torun, Uniwersytet Mikolaja Kopernika (p. 59)
}

07 Master's Degree in Library and Information Science (Bibliotekoznawstwa i Informacji Naukowej)

09 Świadectwo maturalne i egzamin wstępny.

10 Studia stacjonarne: składanie świadectw do 15.06. Egzaminy wstępne-począ tek lipca. Rospoczęcie studiów-początek października; Studia zaoczne: składanie świadectw do 15.05. Egzaminy wstępne-pochątek czerwca. Rozpoczęcie studiów-październik.

12 Nabycie szerokiej wiedzy do pracy w bibliotekach różnego typu.

13 Całość studiów jest rozłożona na trzy rodzaje przedmiotów: przedmioty obowiązkowe, przedmioty specjalizacyjne (do wyboru) i przedmioty uzupełniające (do wyboru).

14 Podstawy bibliologii i bibliotekoznawstwa; Organizacja i funkcje bibliotek; Gromadzenie zbiorów; Katalogowanie zbiorów (kurs podstawowy)'; Klasyfikacja rzeczowa; Czytelnictwo; Informacja naukowa (kurs podstawowy); Działalność informacyjna bibliotek; Pracownia komputerowa podstawowa; Historia dawnej książki i bibliotek (kurs podstawowy); Książka w komunikacji społecznej XIX i XX w.; Bibliografia (kurs podstawowy); Praktyka.

Bibliografia (kurs wyższy); Historia dawnej książki i bibliotek (kurs wyższy); Książka w komunikacji społecznej XIX i XX w. (kurs wyższy); Katalogowanie zbiorów (kurs wyższy); Katalogowanie zbiorów specjalnych; Czytelnictwo; Historia nauki; Naukoznawstwo; Informacja naukowa (kurs wyższy); Pracownia komputerowa specjalna (programy bazowe); Biblioteki publiczne -organizacja i funkcje; Biblioteki szkolne-organizacja i funkcje; Edytorstwo; Księgarstwo; Konserwacja zbiorów bibliotecznych; Teoria komunikacji społecznej ; Zajęcia specjalizacyjne o zmiennej tematyce;

15 Praktyka jest przewidziana w różnych miastach Polski w bibliotekach różnego typu.

17 Studia trwają 5 lat.

18 Bibliotekarze na różnych stanowiskach w bibliotekach różnego typu. 


$\begin{array}{ll}\text { ACADEMIC SUBJECT: } & \text { Library and Information Science } \\ \text { COUNTRY: } & \text { Poland } \\ \text { CITY, INSTITUTION: } & \text { Warszaw, Uniwersytet Warszawski (p. 60) }\end{array}$

07 Magister Artium (MA), Diploma in Information Science for Teachers (post-graduate)

09 Der Bewerber muß ein Abitur oder vergleichbares nachweisen und an einem Qualifikationsgespräch teilnehmen. Für den postgraduierten Studiengang ist ein Qualifikationsgespräch obligatorisch. - Pro Semester können für das Tagesstudium 100, das Fernstudium 50 und das postgraduierte Studium 30 Studenten aufgenommen werden.

10 Die Bewerbungsfrist ist für das Tages- und das Fernstudium der 10. Juni, für das postgraduierte Studium der 15. August eines jeden Jahres.

11 Immatrikulation für das Tages- und Fernstudium ist der 1. Oktober, für das postgraduierte Studium der 1. September.

12 Von Beginn an orientierte sich dieses Institut an moderner Bibliothekswissenschaft mit einem speziellen Schwerpunkt in Informationswissenschaft. Mit der Zeit wurde diese Methode konsequent weiterverfolgt. Wir arbeiten mit der Annahme, daß die Bibliotheken heute und morgen davon abhängen, wie sie moderne Methoden des Informationstransfers in konventioneller Weise, aber auch in neuer, elektronischer Weise in ihre Arbeit integrieren. Informationswissenschaft wird von uns verstanden als Organisation von den sozialen Prozessen der Kommunikation über Quellen, die den ganzen Bereich des "geisteswissenschaftlichen" und sozialen Wissens wie die technischen Möglichkeiten berühren. Ziel der Ausbildung am Institut ist die Vorbereitung qualifizierter Personen zur Arbeit in Einrichtungen, die dem Buch oder Dokument verbunden sind. Das postgraduierte Studium ist für Hochschulabsolventen gedacht, die ihre Qualifikationen in der Informationswissenschaft erwerben wollen. Besonderer Schwerpunkt bilden die modernen Methoden der Informationsvermittlung.

13 Die ersten zwei Jahre des Tages- und Fernstudiums dienen der allgemeinen Ausbildung. Im dritten Jahr wählen die Studenten den Fachunterricht und die Seminare. Im postgraduierten Studium werden nur Vorlesungen und Prüfungen, aber keine Seminare durchgeführt.

14 Studieninhalte im Tagesstudium: Einführung in Bibliotheks- und Informationswissenschaft; Bibliographie und andere Informationsquellen; Regeln der Dokumentenkatalogisierung; Katalogisierung und Klassifikation; Computertools in der wissenschaftlichen Information; Bibliothekssammlungen; Lesestudien; Publizieren und Buchhandel; Statistik; Elemente der Mathematik; Logik; Geschichte des Lernens der Wissenschaft; Geschichte der polnischen Literatur; Geschichte des Buches, der Bibliotheken und der Informationswissenschaft; Theorie der Kultur; Geschichte der Kultur; Soziologie; Ökonomie; Proseminar in Methodik; Fremdsprachen; ausgewählte Probleme der vergleichenden Bibliothekswissenschaft; Geschichte der Bibliographie; Geschichte der Kunst; Probleme in Kinderbibliotheken; Rolle des Schreibens in der Kultur; Softwareanwendungen; Bibliotheken und 
Bibliotheksmanagement; gegenwärtige Entwicklungen in Bibliotheks- und Informationswissenschaft.

Im Schwerpunkt Informationswissenschaft (nach 5 Semestern) werden folgende Veranstaltungen abgeboten: Indexieren und Abstracting von Dokumenten; Datenbanken; Elemente des Information Retrieval, Systemanalyse und Systemdesign; Heuristik von Information; Sprachen des Information Retrieval; Bibliotheksautomation; linguistische Grundlagen in Informationssystemen; Organisation und Management von Bibliotheken und Informationszentren; Informationsbenutzer; Vorlesung (1991/92) "Information and social systems. A review of reference publications".

15 Praktika sind im Tages- und Fernstudium vorgesehen. Praktika können in zwei Wochen im ersten und zweiten Studienjahr durchgeführt werden. Auslandspraktika können in Deutschland und den Niederlanden durchgeführt werden.

16 Zahlreiche Prüfungen nach jedem Semester im Zeitbereich von zwei Wochen.

17 Tages- und Fernstudium: 5 Jahre; postgraduiertes Studium: 1,5 Jahre

18 Absolventen finden Berufe in Bibliotheken, Informationszentren, Buchhandlungen, Rechenzentren, Verlagsanstalten.

! Für das Fernstudium und den postgraduierten Studiengang werden Studiengebühren erhoben.

ACADEMIC SUBJECT:

\section{COUNTRY:}

CITY, INSTITUTION:

\author{
Library and Information Science \\ Poland \\ Wrocław, Uniwersytet Wrocławski (p. 61)
}

07 Master of Arts (MA) in Library and Information Science Study

09 For Polish students: secondary school certificate and passing the initial exams (Polish Literature, history and foreign language). For foreigners: please consult Uniwersytet Wrocławski, Dział Nauczania, Wrocław, Pl. Uniwersytecki 1 (Tel: +48(0)71-40.22.37). Limitations concerning admission for full-time students age below 25 years old. 40 students can start studies each term.

10 June 15 th of each year.

11 First of October

1313 basic subjects; 9 supplementary subjects; 3 specialization seminars

14 The course of studies is the same for all students (constant scheme).

15 Practical studies are intended. 
16 All exams are obligatory on each year level. The final university examination must be passed within 2 years after finishing the study.

175 years

18 Librarian (in school, public, special library) Information Services staff, editors.

$\begin{array}{ll}\text { ACADEMIC SUBJECT: } & \text { Library and Information Science } \\ \text { COUNTRY: } & \text { Romania } \\ \text { CITY, INSTITUTION: } & \text { Bucureşti, Universitatea Bucureşti (p. 65) }\end{array}$

07 Diplômé en Bibliothéconomie et Sciences de l'Information

08 2ème cycle; temps plein

09 Sur examens (sans conditions spéciales).

1050 étudiants sont admis chaque année.

11 1er octobre

12 Bibliothécaire et Documentaliste

13 Il y a des cours, des séminaires et des travaux pratiques (chaque semestre 3 semaines).

15 Chaque année 3 semaines (en juin); chaque année des opérations de plus en plus compliquées; un stage ou un séjour à l'étranger ne sont pas encore possibles.

16 Il y a des examens de culture générale et des examens de spécialité.

$17 \quad 4$ ans

18 Bibliothécaire, Documentaliste

! Changements de l'emploi du temps possibles avec l'avis du ministère de l'enseignement. Notre section a été créée en 1990.

ACADEMIC SUBJECT: COUNTRY: CITY, INSTITUTION:
Library and Information Science

Slovakia

Bratislava, Univerzita Komenského Bratislava (p. 69)

07 Master of Arts (MA), Doctor of Philosophy (PhD) in Library and Information Science 
08 2nd level; full-time

09 Graduation diploma from a grammar school or an equivalent school and pass admission examinations.

10 End of February of each year.

11 First of September

12 To prepare experts for management and organization of libraries, all kind of library services, projection and utilization of computerized systems, data processing.

13 The study is divided into 10 terms. In every term are obligatory and optional lectures, seminars or proseminars.

14 After the second year the study is divided into studying orientations: work with children and young users, Library and Information Services, Library Information Technologies, Information Analysis. According to general needs and interest may be installed some other specialization.

Examples: Introduction to Library and Information Science, Information Resources, Organization and Utilisation of Information Resources, Theory of Librarianship Background, Library and Information Systems, Research Methodology in Library and Information Science, Library an Information Services, Social Science Information, International Library and Information Associations and Programmes, State Information Policy.

15 Practical studies are intended

16 Exams have to be taken on the end of every term.

175 years $(=10$ terms $)$

18 Librarians, information specialists at information institutions, teachers at library schools of all kinds.

ACADEMIC SUBJECT:

COUNTRY:

Library and Information Science

CITY, INSTITUTION:

$$
1 \text { Spain }
$$

Barcelona, Escola Universitària Jordi Rubió i Balaguer (p. 70)

07 Diplomats Universitaris en Biblioteconomia i Documentació

08 Graduaran els primers diplomats universitaris.

09 Actualment sélabora un nou pla d'estudis d'acord amb les noves directrius establertes en el pla indicatiu publicat recentment. 
12 Els estudis estan enfocats a la formació de professionals polivalents que puguin treballer en bibliotheques, centres de documentación i arxius. La seva funció en aquests centres serà posar la informació a l'abast dels usuaris. La preparació dels professionals de la informació demana uns estudis de caràcter general i instrumental que els proporcioni recursos per satifer tota mena de necessitats informatives.

13 Les classes es fan de dilluns a divendres en torns de matí o tarda.

14 Primer curs: Anàlisi documental I, Bibliografia I, Biblioteconomia I, Història (mètodes i font de la recerca històrica), Història del llibre i des les biblioteques, Idiomes moderns (anglès o francès), Literatura universal contemporània, Metodologia de le recerca, terminologia.

Segon curs: Anàlisi documental II, Arxivística I, Bibliografia II, Biblioteconomia II, Classificació i indexació, Documentació, Idiomes moderns (anglès o francès), Paleografia Tercer curs: Assignatures quadrimestrals obligatòries: Documentació II, Informàtica i automatització de biblioteques, Restauració i enquadernació. Assignatures quadrimestrals opcionals: Arxius administratius, Arxivística II, Bases de dades, Cultura i novas tecnologies, Documents musicals, Formats bibliogràfics, Gestio de biblioteques, Llibre antic, Llbre infantil, Materials no-llibres, Paquets de gestió documental, Patalogia del paper, Publicacions en sèrie.

173 curs

! Els recursos actuals de l'escola per donar suport a 1 tasca docent són: una biblioteca especialitzada, un labaratori d'informàtica i teledocumentació i un taller de restauració i enquadernació.

\author{
ACADEMIC SUBJECT: \\ Library and Information Science \\ COUNTRY: \\ CITY, INSTITUTION: \\ Spain \\ Madrid, Universidad Carlos III de Madrid (p. 72)
}

07 Diplomado en Biblioteconomía y Documentación; Master en Información y Documentación

09 Para la Diplomatura: Prueba de selectividad superada, o matrícula en otra carrera universitaria; En la Diplomatura, las que marque el Ministrio de Educación. Para el Master: Título de Licenciado y superación de la prueba de acceso; existe "numerus clausus".

12 Preparan especialistas en Información y documentación.

13 Undergraduate degree programme: Students must complete 208 credits out of which 154 are made up of compulsory courses. The remaining credits are distributed between optional courses offered within the department, and courses offered interdepartmentally by the Business Administration Department, the Economics Department, the Computer Science Department, the Humanities Department or the Law Department. In addition, 
students must complete two months of practical work experience at designated libraries or information centres.

Graduate programme: In addition to the 8 core competence modules, there are 7 seminars, which address specific issues in Library Automation, Networks for Interlibrary Loan, etc. The student must complete all 8 modules, and present an independent research project supervised by department faculty. In addition, students are encouraged to complete a 3 month work experience at selected libraries or information centres.

14 The undergraduate degree programme has the following main areas of competence: Information Technologies, Information Control and Retrieval, Reference, Management, Records Management.

The graduate programme has the following areas of competence: Information Theory, Information Management, Information Resources, Information Retrieval, Information Technologies, Information Services, Information Production, Information Polices

15 Se realizan prácticas; existe la posibilidad de realizar prácticas en el extranjero.

17 Tres años para la Diplomatura, uno para el Master

! As a pre-requiste for graduation, students must also satisfactorily fulfill the englisch Language requirement set internally by the University.

The graduate programme has the academic support of the Consejo Superior de Investigaciones Científicas, the Spanish Science Research Council, and the financial support of private institutions in the Spanish Information Industry.

ACADEMIC SUBJECT:

COUNTRY:

Library and Information Science

CITY, INSTITUTION:

Sweden

Borås, Högskolan i Borås (p. 75)

07 Master in Library and Information Science

09 Normal university entry requirements and at least 2 year's university studies; total number: 480 ; number of students of each intake: 120

11 Last day for submitting applications: First of April (for Autum semester), first October (for Spring semester)

12 The programme is required to prepare for professional work in all kinds of libraries and in related cultural and information institutions; more specifically, its aims are a) to prepare students for the library and information profession by introducing them to the media, activities and tools relevant to institutions encompassing the profession; b) to provide students with a sound and all-round understanding of the role in society of both libraries and information centres as well as of librarians and information workers; c) to develop in students the ability to view critically the aims and objectives of libraries and information centres and their different activities; d) to give students such prerequisites so that as professionals, they may actively participate in the influence the management and dissemination of information in the broad sense of the term. 
14 First semester: Libraries and Society, Libraries and Information Technology, Reference and Bibliography, Types of Catalogues, Classification; semester 2-3 (academic and special libraries option, ASL), Cataloguing, Classification and Indexing, Sources of Information, Information Technology, Collection Management, Administration, Fieldwork (practicum); Semester 4: Automated Library Systems; Three Electives of Information Provision in Corporate and Public-service Organizations, The Economics and Politics of Information, History of Books and Libraries, Technical and Scientific Library and Information Services

15 Practical work is in curriculum intended.

172 years

! Students do not have to pay any tuition

$\begin{array}{ll}\text { ACADEMIC SUBJECT: } & \text { Library and Information Science } \\ \text { COUNTRY: } & \text { United Kingdom } \\ \text { CITY, INSTITUTION: } & \text { Aberdeen, Robert Gordon University (p. 80) }\end{array}$

07 Bachelor of Arts (BA (Hons)), Master of Arts (MA Hons)), Doctor of Philososphie (PhD) in Library and Information Studies

08 1st, 2nd and 3rd level; full-time, part-time

09 The minimum qualifications are: SEC 5 (No. of Subjects), $3 \mathrm{H}-$ levels and English $\mathrm{H}$ (Subject Requirements) or GCE 5 (No. of Subject), 2 H-levels (Subject Requirements). In addition to these minimum requirements, the equivalent of 2 " $B$ " passes at Higher Grade or " $\mathrm{D}$ " passes at Advenced Level is normally required. For mature students (i.e., over 21 ), other equivalent qualifications may be accepted.

11 All applications for RGU undergraduate courses should be made to the University Central Admissions System (CAS). If you are not at school or college you may obtain them directly from CAS, PO Box 67, Chettenham, UK-Gloucestershire, GL50 3SF. Applications should reach CAS between 1 September and 15 December of the year before entry.

12 The aim of the course is to provide an educational programme in preparation for a career as librarian or information officer in a rapidly changing society. These vocational and broadly-based courses concentrate on the role of librarians and information services in the provision of information directly relevant to the needs of their users and, in addition, consider the social and technological context in which they operate.

14 Bibliographic and Information Studies, Information Retrieval and Management, Information Technology

15 Projects and practical work form an integral part of all subject areas. 
$17 \quad \mathrm{BA}=3$ years; $\mathrm{BA}($ Hons $)=4$ years

18 A wide variety of libraries and information centres, and positions outwith information work.

! UK \& EC domicil self-financing: $£ 666$ p.a. UK \& EC domiciled sponsored students, e.g., SOED, LEA Empolyer: $£ 1775$ p.a.

\begin{tabular}{ll} 
ACADEMIC SUBJECT: & \multicolumn{2}{l}{ Library and Information Science (postgraduate) } \\
COUNTRY: & United Kingdom \\
CITY, INSTITUTION: & Aberdeen, Robert Gordon University (p. 80)
\end{tabular}

07 Postgraduate Diploma, Master of Arts (MA), Master of Science (MSc) in Library and Information Studies

08 2nd and 3rd level, part-time

09 A degree of a University of the United Kingdom or a degree of the Council for National Academic Awards or a degree from an Overseas University, or degree equivalent qualifications, subject to the approval of this Institute.

11 Application forms are available from and should be returned to the Admissions Office, RGU, Schoolhill, UK-Aberdeen, AB9 1FR (Tel: +44(0)224-63.36.11)

12 The aim of the course is to prepare students for a professional career in a rapidly changing society. It concentrates on the provision of information through library and information services, and on the technological context in which they operate. It seeks to develop the intellectual rigour necessary to make informed, critical judgements on theoretical and practical matters.

13 The first part of the course is full-time for one session, consisting of three eleven week terms. Students who successfully complete this part of the course and who do not wish to proceed a Masters degree will be awarded the postgraduate Diploma. Students who proceed to the Masters degree will continue on a part-time basis for 4 months whilst preparing their dissertation. In the first part of the course, studies are arranged so that staff; student contact time is concentrated in the first term to afford the student time to complete project work and also prepare for written examinations. The timetable allows for a flexible pattern of smallgroup teaching, lectures, individual tutorials and practical work.

14 Bibliographic and Information Studies, Information Retrieval, Information Technology, Management, Research Methodology, Dissertation.

15 A four week placement in a suitable library or information unit is undertaken as an integral and compulsory part of the course.

$17 \quad 11 / 2$ years 
18 A wide variety of libraries and information centres, and positions outwith information work.

! UK \& EC domiciled self-financing: $£ 666$ p.a. UK \& EC domiciled sponsored students, e.g., SOED, Employer: $£ 2650$ p.a . CNAA Registration Fee: $£ 25$

\author{
ACADEMIC SUBJECT: Library and Information Science \\ COUNTRY: \\ CITY, INSTITUTION: Birmingham, University of Central England (UCE) in \\ Birmingham (p. 82)
}

07 Postgraduate Diploma, Master of Arts (MA), Master of Science (MSc) in Librarianship and Information Studies

08 2nd level; full-time, part-time

09 Honours degree; 30 Students can start full-time course per annum; 20 Students can start part-time course per cohort and per annum.

10 No deadline for enrolment, but course may fill up.

11 September/October of each year.

12 The overall aim is to provide the student with the opportunity to undertake an investigation of existing knowledge within a specified and agreed subject area, and to present a critical discussion based upon that investigation. Within this overall aim, to provide the student with the opportunity to a) apply analytical skills developed in the Diploma to a detailed study of a selected subject, b) gain an understanding at first hand of the importance of objectivity in research and c) produce a significant contribution to the literature of a selected subject.

13 Induction programme (3 days), foundation course (2 weeks), core papers (23 teaching weeks), core modules ( 3 weeks) optional papers ( 25 teching weeks), award of diploma, dissertation.

14 Information Resources; Information Retrieval; Management and Organizational Studies; The Information Society; Professional Issues; The Research Process; Community Librarianship; Local Studies; Young People; Arts and Media Promotion; Information Networks; Information Design; Science; Technology and Industry; Business Information

15 Practical studies are intended.

16 The assessement will be based entirely on the dissertation.

17 1 year 
ACADEMIC SUBJECT: COUNTRY: CITY, INSTITUTION:

\author{
Library and Information Science \\ United Kingdom \\ Brighton, University of Brighton (p. 83)
}

07 Bachelor of Arts (BA (Hons)), Master of Arts (MA) in Library and Information Studies

08 1st and 2nd level; full-time, sandwich

09 Five GCSE, too at A-level or four at AS-level; English or Mathematics at O-level or the equivalent; maximum number of students decided each year (currently 45).

10 At the beginning of the autumn term of each academic year, all full-time students (and those sandwich course students not in industry) are required to go through a process of enrolment. Full detail of this process are posted to new students.

12 This course focusses on information transfer-or where information comes from, how it is organized, distributed and used it. It aims to provide knowledge and skills for graduates to work in the wide and growing range of contemporary information and communication industries. In addition to knowledge and skills particular to information work, the course seeks to promote competences related to the interpersonal and problem-solving dimension which are to be found in any work situation.

14 The course is designed around a group of core components, supported by areas of advanced specialist study of which two are choosen: core components: Information Science, Information Environment, Management; specialist studies: Book Studies, Computer Systems Studies, Media Studies.

15 A one month placement in the summer term of the first year allows students to draw together all aspects of the first year courses in an applied environment.

16 The second year is entirely course-assessed, and the first and third year are a mixture of course-assessed work (taking $40 \%$ of the marks) and examinations (taking 60\%). Largescale individual and group projects form a major part of the course-assessed work, and all students must complete a third-year dissertation on a topic of relevance to Library and Information Studies.

173 years (full-time)

18 Future information professionals may work in any of the 93.000 libraries in Europe, or in voluntary information and advice centres, or in some part of the newspaper, magazine and book publishing and audio-visual industries, or in information services based on applications of computing and telecommunications. The course is accredited by the Library Association and by the Institute of Information Scientists, but it has been designed to provide graduates with a broad base knowledge and transferable skills from which a variety of career opportunities may develop. We also visualize opportunities for our graduates in rewarding and interesting jobs in the EC and further afield. 
! Students who have competed three years' ordinary residence within the EC will be assessed at the EC rate for fees purposes.

\author{
ACADEMIC SUBJECT: Library and Information Science \\ COUNTRY: $\quad$ United Kingdom \\ CITY, INSTITUTION: London, University College of London (p. 88)
}

07 Diploma, Master of Arts (MA), Master (MPhi) and Doctor (PhD) of Philosophy in Arts in Library and Information Studies

08 2nd and 3rd level; full-time, part-time

09 Normal entrance requirements are a good first degree and an acceptable professional qualification.

10 Deadline for enrolment is last of March of each year.

11 Studies start in October.

12 This course aims to provide an understanding of a full range of professional knowledge and an appreciation of the skills and techniques relevant to library and information work.

13 The Diploma course consists of lectures, group work, tutorials and seminars, demonstrations and visits to libraries, presses and other professional and commercial organizations.

14 Introduction to Automation; subject study: Documentary and Information Sources; Cataloguing, Classification, Indexing and Retrieval of Information; Management of Libraries and Information Services; options: Historical Bibliography; Oriental and African Bibliography; The Communication of Research Information; Business Information; Modern Printing and Book Trade; Manuscript Studies; Special Materials and Techniques in Libraries and Archives; Studies in Educational Librarianship; Advanced Studies in Automation.

15 Practical work is intended.

16 Candidates are required to take three written papers, contributing to the assessment.

17 For full-time students: one year; for part-time students: two years

! Composition fees in any session become payable. 
ACADEMIC SUBJECT:

COUNTRY:

CITY, INSTITUTION:

\section{Learning Resource Centre Management}

United Kingdom

Newcastle upon Tyne, University of Northumbria at Newcastle (p. 92)

07 Diploma in Learning Resource Centre Management

08 2nd level; full-time, part-time

09 Diploma: 48 full-time, 10 part-time

10 The deadline for enrolment is the first day of course. Applications should be submitted as soon as possible in previous academic year.

11 The studies start September annually.

12 To prepare graduates for employment, particulary in information and library environments. To provide students with a learning experience which will enable them to think critically and to apply their knowledge and abilities.

13 Currently 3 term year; moving to $2 \times 15$ week semesters in 1994. Average 15 hours per week; $50 \%$ lecture and $50 \%$ practical; seminars.

15 Practical studies are compulsory. Practical studies can be carried out; possibilities to have practical studies in foreign countries.

16 No exams; All have continuous assessment of course work.

172 years (4 hours per week / 60 weeks)

18 Information officers and Librarians in wide range of institutions. IT related posts in business and industry.

! Unitisation across institutions to allow wider choice of options. PG Diploma Information and Records Management to be offered from September 1992. BSc Communication analysis with Languages and Information Technology from September 1994. 


$\begin{array}{ll}\text { ACADEMIC SUBJECT: } & \text { Library and Information Management } \\ \text { COUNTRY: } & \text { United Kingdom } \\ \text { CITY, INSTITUTION: } & \text { Sheffield, University of Sheffield (p. 93) }\end{array}$

07 Master of Arts (MA) in Library and Information Management

08 2nd level; full-time, part-time

09 The Programme is open to applicants with either 2 years relevant operational experience in library and information work.

11 Early applicants are advised but in any case should be received by 31 th March.

12 The Professional Development Programme is designed to provide those who already have experience in librarianship or information work with an opportunity to study for a higher degree at Master's level by a combination of course work and dissertation.

13 The exact form of each students' pattern of study will be determined in consultation with staff.

14 These studies will be take place within the following broad framework: Library and Information Systems and Services (including Management); Computer Applications in Library and Information Work; Information Resources; Information Retrieval.

16 The programme includes an opportunity to visit a number of library and information organizations during the terms.

171 year (full-time); 2 years (part-time).

ACADEMIC SUBJECT:

COUNTRY:

CITY, INSTITUTION:

\author{
Library Science \\ Croatia \\ Zagreb, Sveučilišta u Zagrebu (p. 5)
}

07 Diploma in Librarianship; Informatology-Stream Libarianship

08 2nd level

09 Librarianship: 2 years of basic faculty programme completed; Informatology-Stream Librarianship: high school final examination (matura) completed

11 Beginning of Autumn term.

12 To enable students to master the necessary skills and techniques required for successful performance of library tasks in all types of libraries. To allow them to acquire the basic 
knowledge of the theory of Librarianship and Information Science and understanding of it's purpose, functions and services.

14 First year: Foundation of Librarianship; Library Administration; Bibliographic Organization and Control; History of Libraries and Book; Theory of Information and Communication, Information Services; second year: Book Protection and Conservation; Classification and Classification Systems; Creation of Databases; an elective course: University Libraries, Public Libraries, School Libraries, Special Libraries, Slavic Written Systems, Publishing and Book Trade, two foreign languages.

15 During the winter holidays after the 2 nd term

16 All previously quoted courses finish with an exam, the final exam is a piece of written text on a library subject chosen at a recommendation of a student's tutor.

18 Librarians' job in all types of libraries

\section{ACADEMIC SUBJECT: COUNTRY: \\ CITY, INSTITUTION:}

\author{
Library Science \\ Denmark \\ København, Danmarks Biblioteksskole (p. 7)
}

07 Librarian R.S.L. in Basic Library \& Information Studies

12 The objective of this new education was to establish a course of study characterized by: flexibility and freedom of choise, emphasis on theory and method, individual independent study effort.

13 The study course is organized in modules.

14 First term: Culture and Information and Society; second term: Basic Course of Library Science; third term: pratical period; fourth term: Material selection and Mediation; fifth and sixth term: compulsory course: economics and administration, basic information science focusing on the interacting between users and information systems; seventh term: two series of seminars; eight term: preparing a thesis

15 Pratical studies are intended.

178 semesters 


$\begin{array}{ll}\text { ACADEMIC SUBJECT: } & \text { Library Science } \\ \text { COUNTRY: } & \text { Germany } \\ \text { CITY, INSTITUTION: } & \text { Berlin, Freie Universität Berlin, IfBB (p. 31) }\end{array}$

07 Magister Artium (MA), Doktor der Philosophie (Dr. phil.) in Bibliothekswissenschaft

09 Allgemeine Hochschulreife oder fachgebundene Studienberechtigung (geeignete abgeschlossene Berufsausbildung und vierjährige Berufserfahrung)

10 1. Juni bis 15. Juli eines jeden Jahres.

11 Zum Wintersemester eines jeden Jahres.

12 Die Bibliothekswissenschaft hat die Aufgabe, die fachlichen Probleme in Bibliotheken und anderen Sammelstätten sowie informationsvermittelnden Einrichtungen mit wissenschaftlichen Methoden zu erfassen und zu analysieren.

13 Bibliothekswissenschaft kann als Nebenfach in Magisterstudiengängen gewählt werden. Das Studium besteht aus Grund- und Haupstudium.

14 1. Geschichte; Struktur und Typologie des Buch-, Bibliotheks- und Dokumentationswesens; 2. Organisation und Betrieb von Bibliotheks- und Informationseinrichtungen; 3. Erfassung; Erschließung und Präsentation von spezifischer Information; 4. Herstellung; Verbreitung und Rezeption von Publikationen und Informationsmedien; 5. Organisation der Wissenschaft, der Bildung, der Forschung; 6. Wissenschaftskunde: Überblick über Systematik und Inhalt der Wissenschaften; 7. Erforschung des Informationsbedarfs; Bibliotheks- und Informationsdidaktik; Zusatzstudium Fachinformation: Grundlagen; Bedarfsanalyse und Ressourcenmanagement; spezielle Informations- und Kommunikationssysteme; Informationsquellen; Inhaltliche Erschließung; Information Retrieval; Spezielle Fachinformationsdienste und -leistungen; Projektarbeit

15 Praktika sind nicht vorgeschrieben, aber erwünscht.

16 Während des Studiums sind Leistungsnachweise zu erwerben, am Ende steht die Magisterprüfung.

17 Regelstudienzeit 8 Semester, durchschnittliche Studiendauer 10 Semester.

18 Tätigkeiten in Bibliotheks-, Informations- und Dokumentationseinrichtungen, bei der Presse, in Verlagen, etc. 


$\begin{array}{ll}\text { ACADEMIC SUBJECT: } & \text { Library Science } \\ \text { COUNTRY: } & \text { Germany } \\ \text { CITY, INSTITUTION: } & \text { Berlin, Freie Universität Berlin, IfBB (p. 31) }\end{array}$

07 Diplombibliothekar an Öffentlichen Bibliotheken

08 1. Ebene; Vollzeitstudium

09 Allgemeine Hochschulreife oder fachgebundene Studienberechtigung (geeignete abgeschlossene Berufsausbildung und vierjährige Berufserfahrung). Es gibt universitätsinterne Zulassungsbeschränkungen.

10 1. Juni - 15. Juli eines jeden Jahres.

11 Zum Wintersemester eines jeden Jahres.

12 Der Studierende soll auf die vielfältigen Aufgaben an öffentlichen Bibliotheken vorbereitet werden. Dazu gehören u.a. Beurteilung und Auswahl der Medien, Umgang mit elektronischen Datenbanken, Orientierung an Benutzerinteressen.

13 Das Studium gliedert sich in ein Grund- und ein Wahlpflichtstudium.

14 Geschichte, Struktur und Typologie des Buch-, Bibliotheks- und Dokumentationswesens, Organisation und Betrieb von Bibliotheks- und Informationseinrichtungen, Erfassung, Erschließung und Präsentation von spezifischer Information, Herstellung, Verbreitung und Rezeption von Publikationen und Informationsmedien, Organisation der Wissenschaft, der Bildung, der Forschung, Wissenschaftskunde: Überblick über Systematik und Inhalt der Wissenschaften, Erforschung des Informationsbedarfs, Bibliotheks- und Informationsdidaktik.

15 Praktika sind vorgesehen.

16 Leistungsnachweise während des Studiums, am Ende steht die Diplomprüfung.

176 Semester

18 Bibliotheken, Informationsmanagement der Wirtschaft und Verwaltung, Kulturmanagement

$\begin{array}{ll}\text { ACADEMIC SUBJECT: } & \text { Library Science } \\ \text { COUNTRY: } & \text { Germany } \\ \text { CITY, INSTITUTION: } & \text { Berlin, Freie Universität Berlin, IfBB (p. 31) }\end{array}$

07 Diplombibliothekar in Wissenschaftlichen Bibliotheken 
09 Allgemeine Hochschulreife. Es gibt eine universitätsinterne Zulassungsbeschränkung.

10 Bewerbungsfrist vom ca. 1. Juni bis 15. Juli. Unterlagen sind beim Zulassungsbüro der Freien Universität Berlin, Boltzmannstr. 3, D-14195 Berlin anzufordern.

11 Beginn des Studiums ist jeweils das Wintersemester (Mitte Oktober).

12 Allgemeines Ziel der Ausbildung ist die Heranbildung von Bibliothekaren, die in ihrem zukünftigen Arbeitsbereich in fachlicher und gesellschaftlicher Hinsicht verantwortungsbewußt und zu innovativem Verhalten befähigt ihren Beruf ausüben. Als besonders fachspezifische Ausbildungsziele sind zu nennen: Kenntnis der Betriebsorganisation von Bibliotheken und Informationseinrichtungen; Fähigkeit, verschiedene bibliothekarische, bibliographische, betriebswirtschaftliche und technische Arbeitsmethoden anzuwenden; Kenntnis der Literatur und Wissenschaft im Überblick; Fähigkeit, neue Wege in der Bibliotheksarbeit zu beschreiten und alte kritisch zu bewerten.

13 Das Studium beginnt mit einem einjährigen Praktikum mit studienbegleitendem Unterricht an einer Ausbildungsbibliothek. Es folgen vier Semester theoretischen Studiums. Praktikumsplätze werden vom Institut vergeben.

14 Geschichte, Struktur und Typologie des Buch-, Bibliotheks- und Dokumentationswesens, Organisation und Betrieb von Bibliotheks- und Informationseinrichtungen, Erfassung, Erschließung und Präsentation von spezifischer Information, Herstellung, Verbreitung und Rezeption von Publikationen und Informationsmedien, Organisation der Wissenschaft, der Bildung, der Forschung, Wissenschaftskunde: Überblick über Systematik und Inhalt der Wissenschaften, Erforschung des Informationsbedarfs, Bibliotheks- und Informationsdidaktik.

15 Praktika sind vorgesehen.

16 Die Leistungsnachweise während des theoretischen Teils des Studiums müssen in den Lehrveranstaltungen des Grundstudiums wie in denen des Wahlpflichtstudiums (Seminare und Übungen) erbracht werden.

17 Drei Jahre (6 Semester)

18 Die Tätigkeiten der Diplombibliothekare an wissenschaftlichen Bibliotheken (z. B. Hochschul- Forschungs-, Firmenbibliotheken, wissenschaftlichen Stadtbibliotheken) umfassen Aufgaben in der Bibliotheksverwaltung, bei bibliographischen Recherchen, in der Formalkatalogisierung, dem Informationsdienst in Auskunft und Lesesaal und bei der Leitung kleiner Instituts- und Spezialbibliotheken. 


\section{ACADEMIC SUBJECT: COUNTRY: CITY, INSTITUTION:}

\author{
Library Science \\ Germany \\ Berlin, Humboldt-Universität, Institut für Bibliotheks- \\ wissenschaft (p. 34)
}

07 Magister Artium (MA), Doktor der Philosophie (Dr. phil.) der Bibliothekswissenschaft

08 2. und 3. Ebene; Vollzeitstudium; das Magisterstudium umfaßt die Ausbildung im Hauptfach Bibliothekswissenschaft sowie das Studium in einem weiteren Hauptfach oder zwei Nebenfächern. Als Zweit- oder Nebenfächer können Wirtschaftswissenschaft, Germanistik, Asienwissenschaft, Informatik, Kunstwissenschaft, Biologie, Philosophie, Geschichte und Geographie studiert werden.

09 Voraussetzung für die Zulassung ist die allgemeine Hochschulreife. Praktische Berufserfahrungen aus der Tätigkeit in Bibliotheken und Informationseinrichtungen sowie gute Fremdsprachenkenntnisse sind wünschenswert, aber keine Bedingung.

10 Bewerbungsschluß ist der Semesterbeginn.

11 Das Studium beginnt jeweils im Wintersemester.

12 Ziel des Studiums ist der Erwerb von theoretischen und praktischen Kenntnissen über Funktion und Arbeitsmethoden des Bibliothekswesens und der Information und Dokumentation, von Fähigkeiten und Fertigkeiten zur Organisation von Informationsprozessen, zur Führung von Bibliotheken und Informationseinrichtungen, zu konzeptioneller Arbeit und zur Realisierung eigener wissenschaftlicher Projekte.

13 Das Studium gliedert sich in vier Semester Grundstudium der Bibliothekswissenschaft und fünf Semester Hauptstudium, das entweder in der Fachrichtung Bibliothekswissenschaft oder in der Fachrichtung Dokumentationswissenschaft durchgeführt wird.

14 Im Grundstudium erfolgt die Ausbildung: a) in den allgemeinbildenden Fächern: Studium generale, Fremdsprachen, Methoden der geistigen Arbeit, b) in den Grundlagenfächern: Grundlagen der Informatik, Grundlagen der Mathematik; Statistik, Wissenschaftskunde, Wissenschaftsforschung, Technik und Technologie in Bibliotheken und Informationseinrichtungen, c) in den Vorlesungsreihen zur Einführung: in das Bibliothekswesen, in die wissenschaftliche Kommunikation/Information/Dokumentation, in das bibliographische Grundwissen, in die formale Erschließung, in die Geschichte des Bibliotheks- und Informationswesen.

Im Hauptstudium wird in der Fachrichtung Bibliothekswissenschaft in folgenden Lehrgebieten ausgebildet: Bibliothekstheorie, Bibliotheksverwaltung und -management, Bestandskunde, Katalogisierung, Bibliotheksbenutzung, Bibliotheksgeschichte, Bibliothekstechnik und -technologie, Bibliographiewissenschaft, Buchkunde.

Im Hauptstudium wird in der Fachrichtung Dokumentationswissenschaft in folgenden Lehrgebieten ausgebildet: Wissensaquisition, Wissensrepräsentation, Informationsmanagement, Informationsrecherche, Informationsvermittlung, Angewandte Informatik, Wissensverarbeitung. 
15 Praktika sind obligatorischer Teil des Grund- und Hauptstudiums.

179 Semester

18 Der Einsatz der Absolventen kann sowohl in allen Bereichen des Bibliothekswesens und der Information/Dokumentation erfolgen als auch in Bereichen des Informationsmanagements und des Informationsmarketings der privaten Wirtschaft. Die Entscheidung für ein bestimmtes Berufsfeld wird auch von den gewählten Zweit- bzw. Nebenfächern bestimmt.

! Die gegenwärtige Studienordnung ist noch nicht endgültig bestätigt. Bitte auf jeden Fall aktuelle Informationen anfordern.

\author{
ACADEMIC SUBJECT: Library Science \\ COUNTRY: \\ CITY, INSTITUTION: Bonn, Fachhochschule für das öffentliche Bibliotheks- \\ wesen (p. 34)
}

07 Diplombibliothekar für den Dienst an Öffentlichen Bibliotheken

08 1. Ebene; Vollzeitstudium

09 Abitur oder die allgemeine Fachhochschulreife (Fachabitur). In bestimmten Fällen besteht auch die Möglichkeit, ohne (Fach-) Abitur über eine Einstufungsprüfung zum Studium zugelassen zu werden. - Derzeit bestehen Zulassungsbeschränkungen.

10 Schriftliche Bewerbungen sind zwischen dem 1. Januar und dem 1. Juli des Jahres, in dem das Studium beginnen soll, direkt an die Fachhochschule zu richten.

11 Das Studium beginnt in einem dreijährigen Turnus jeweils zum Wintersemester (Oktober) 1995, 1998 usw.

12 Dem Studenten soll die für die Berufspraxis erforderlichen fachlichen Kenntnisse vermittelt werden. Er soll befähigt werden, auf der Grundlage wissenschaftlicher Erkenntnisse und Methoden bibliothekarische Probleme zu analysieren und zu lösen und in die Lage versetzt zu werden, den Wandel bibliothekarischer Berufs- und Tätigkeitsfelder zu erkennen, sowie bei deren Weiterentwicklung und zukünftigen Ausgestaltung mitzuwirken.

14 Das theoretische Studium gliedert sich in zahlreiche Fächer, die zu drei großen Blöcken zusammengefaßt werden können: Bibliothekswissenschaftliche Fächer, Literatur- und Medienkunde und Wissenschaftskunde.

15 Ein Schwerpunkt des Studiums liegt in der praktischen Anwendung der theoretischen Grundlagen und Kenntnisse im Bibliotheksalltag. Neben den Praktika bieten auch Bibliotheksbesichtigungen und projektbezogene Lehrveranstaltungen Gelegenheit dazu. 
16 Das Studium schließt ab mit dem Diplomexamen, bestehend aus fünf mündlichen Prüfungen, einer Klausur, der schriftlichen Hausarbeit und dem Kolloquium zur Hausarbeit.

176 Semester

18 Der Abschluß qualifiziert vorrangig für eine Tätigkeit in allen Bereichen des Öfentlichen Bibliothekswesen. Unter Umständen ist aber auch eine Anstellung in verwandten Bereichen des Bibliotheks- und Informationswesens möglich.

! Die geringe Zahl von ca. 35 Studienplätzen gewährleistet ein intensives Studium, wobei auch persönliche Interessen berücksichtigt werden können.

ACADEMIC SUBJECT:

COUNTRY:

CITY, INSTITUTION:

\author{
Library Science \\ Germany \\ Hannover, Fachhochschule Hannover (p. 38)
}

07 Diplombibliothekar (FH); zugleich erhalten die Absolventen die Laufbahnbefähigung für den gehobenen Dienst an wissenschaftlichen Bibliotheken.

08 1. Ebene; Vollzeitstudium

09 Allgemeine oder fachgebundene Hochschulreife, bestandene Immaturenprüfung oder einer beim Kultusminister als gleichwertig anerkannten Vorbildung.

10 Bewerbungsschluß ist der 15. Juli. Das Studium wird zum 21. September aufgenommen.

11 Wegen begrenzter Studienkapazität und hoher Bewerberzahlen ist die Zulassung in der Regel beschränkt. Sie erfolgt jeweils zum Wintersemester nach den für Numerus-claususFächern geltenden Rechtsvorschriften durch das Immatrikulationsamt der FH Hannover. Ausländische Interessenten erfahren die für sie geltenden Zulassungsbedingungen beim Institut für ausländische Fachhochschulbewerber.

12 Der Studiengang "Bibliothekswesen" bildet Studenten aus, deren Einsatzbereich die wissenschaftlichen Allgemeinbibliotheken und Spezialbibliotheken in Lehre, Forschung, Wirtschaft und öfentlicher Verwaltung sind.

13 Das Studium gliedert sich in ein zweisemestriges Grund- und ein sechssemestriges Hauptstudium.

14 Pflichtfächer im Grundstudium: Grundlagen des wissenschaftlichen Bibliothekswesen; Grundlagen des Informations- und Dokumentationswesens; Grundlagen der alphabetischen Katalogisierung; Grundlagen der inhaltlichen Erschließung; Grundlagen der Informationsvermittlung; Grundlagen der Informatik; DV-Anwendungen in Bibliotheken. Von den Wahlpflichtfächern muß eines gewählt werden: Grundlagen der Buch- und Bibliotheksgeschichte; Grundlagen des Rechts des Bibliotheks-, Informations- und Dokumentationswesens; Buchbinden, Druck- und Reprotechnik. Pflichtfächer im Hauptstudium: Struktur 
des BID-Wesens; Betriebswirtschaftslehre der wissenschaftlichen Bibliothek; Theorie und Praxis der alphabetischen Katalogisierung; Theorie und Praxis der Informationsvermittlung; Informationssoziologie und -psychologie; Staats- und Verwaltungsrecht; DVAnwendungen in Bibliotheken. Von den Wahlpflichtfächern müssen vier gewählt werden: Ausgewählte Fragen der inhaltlichen Erschließung; Kommunikationstechniken; Ausgewählte Fragen der Buch- und Bibliotheksgeschichte; Verwaltung historischer Bestände; Spezialbibliotheken; Wissenschaftskunde; Informationsrecht; Datenbankprogrammierung; Informatik (Programmiersprachen); Ausgewählte Fragen der Informatik; Bibliotheksbau; Ausgewählte Fragen der alphabetischen Katalogisierung; Informationsdienstleistungen; Öfentliches Bibliothekswesen.

15 Das vierte Semester ist als Praxissemester in einer Informations- und Dokumentationsstelle, einer Bibliothek oder der einer technischen Dokumentationsabteilung zu absolvieren.

16 Diplomvorprüfung am Ende des 2. Semesters. Diplomprüfung im 8. Semester.

178 Semester

18 Berufe im Bibliotheks- und Dokumentationswesen

\author{
ACADEMIC SUBJECT: Library Science \\ COUNTRY: \\ CITY, INSTITUTION: Köln, Fachhochschule für Bibliotheks- und Dokumenta- \\ tionswesen in Köln (p. 39)
}

07 Diplombibliothekar für öffentliches Bibliothekswesen

08 1. Ebene; Vollzeitstudium

09 Voraussetzung für die Aufnahme des Studiums ist die Fachhochschulreife. Da die Zahl der Bewerber die Zahl der zu vergebenden Studienplätze übersteigt, wird ein Zulassungsverfahren durchgeführt.

10 Anfragen nach Bewerbungsunterlagen sind ab Ende Mai an die Zentralstelle für die Vergabe von Studienplätzen (ZVS), Sonnenstraße 171, D-44137 Dortmund zu richten. Bewerbungsschluß ist der 15.7. eines jeden Jahres. Bewerber, die nicht die deutsche Staatsangehörigkeit besitzen und auch keine EG-Bürger sind, richten ihre Bewerbungsunterlagen direkt an die Fachhochschule.

11 Das Studium kann nur im Wintersemester begonnen werden.

12 Das Studium soll im Rahmen der allgemeinen Studienziele einer Fachhochschule dem Studenten die für die Berufspraxis erforderlichen Kenntnisse vermitteln und ihn befähigen, auf der Grundlage wissenschaftlicher Erkenntnisse und Methoden bibliothekarische Probleme zu analysieren und zu lösen. 
13 Der Gesamtumfang beträgt 130 SWS, die sich in Form von Pflicht- und Wahlpflichtveranstaltungen auf sechs Semester verteilen, sowie ein Mindestangebot von 10 SWS als Wahlveranstaltungen.

14 Zum Pflichtstudium gehören die Orientierungsphase, propädeutische Fächer, Grundlagenfächer und bibliothekarische Kernfächer.

Propädeutische Fächer sind: Praktikumsauswertung; Technik des wissenschaftlichen Arbeitens; Bibliothekarische Fachliteratur; Bildungswesen; System der Wissenschaft und Wissenschaftsorganisation. Grundlagenfächer sind: ADV in Bibliotheken; Anwendung der ADV; Formalkatalogisierung, Fachauskunft und Fachbibliographie; Verwaltungskunde und Bibliotheksrecht; Bibliotheksgeschichte; Bibliothekssoziologie; Angewandte Psychologie in Bibliotheken, Leserforschung; Buch- und Medienkunde; Unterhaltungsliteratur in öffentlichen Bibliotheken; Buchhandel; Information und Dokumentation; Bibliothekswesen des Auslandes; Bibliotheksbau, -einrichtung und -technik. Bibliothekarische Kernfächer sind: Bibliothekslehre; Bibliotheksverwaltung; Sacherschließung; Bibliographie und Informationsdienst; Lektoratsbereich (Belletristik oder Kinder- und Jugendliteratur oder Sachliteratur). Das Wahlpflichtstudium richtet sich nach dem Lehrangebot.

15 Jeder Student muß während des Studiums drei Praktika von insgesamt 16 Wochen Dauer in Bibliotheken ableisten.

16 Das Studium schließt mit der Diplomprüfung ab. Die Prüfung besteht aus den Teilen a) b) studienbegleitenden Fachprüfungen, c) der Diplomarbeit und d) dem Kolloquium.

17 Die Regelstudienzeit beträgt einschließlich der Praktika und der Prüfungszeit drei Jahre (=6 Semester).

18 Die Aufgaben des Diplombibliothekars an öffentlichen Bibliotheken liegen vor allem in den Bereichen a) Bestandsaufbau und Bestandserschließung. Dazu gehören Auswahl, Beschaffung und Erschließung der Bestände im Hinblick auf den jeweiligen Benutzerbedarf. b) Benutzerdienste. Hierzu gehören im wesentlichen Informations- und Beratungsdienst sowie Kontakt-, Öfentlichkeits- und Programmarbeit. c) Organisation, Verwaltung und Leitung der Bibliothek.

$\begin{array}{lll}\text { ACADEMIC SUBJECT: } & \text { Library Science } \\ \text { COUNTRY: } & \text { Germany } \\ \text { CITY, INSTITUTION: } & \quad \begin{array}{l}\text { Leipzig, Hochschule für Technik, Wirtschaft und Kultur } \\ \end{array} & \\ & & \text { Leipzig (FH) (p. 41) }\end{array}$

07 Diplombibliothekar

08 1. Ebene; Vollzeitstudium

09 Allgemeine Hochschulreife / Fachhochschulreife

10 Bis zum 15. 09. des jeweiligen Immatrikulationsjahres. 
11 Zum 1.10. eines jeden Jahres.

12 Vorbereitung für eine Tätigkeit als Diplombibliothekar in Öffentlichen und wissenschaftlichen Bibliotheken aller Art sowie verwandten Einrichtungen.

13 Gemeinsames Grundstudium für beide Studienrichtung. Hauptstudium 4. bis 8. Semester getrennt nach den Studieneinrichtungen Öffentlichen Bibliotheken und Wissenschaftliche Bibliotheken. Während des 6. und 7. Semesters Mitarbeit an einem praxisrelavanten Projekt. Im 8. Semester Anfertigung der Diplomarbeit.

14 Grundstudium mit den Schwerpunkten: Bibliothekstypologie, Bibliographie, Formalerschließung, Bestandsvermittlung, Grundlagen der Informationstechnologie, Bibliotheksgeschichte. Hauptstudium Öffentliche Bibliotheken: Bestandsaufbau und Erwerbung, Sacherschließung, Literaturbewertung und -vermittlung, Kinder- und Jugendbibliotheken, soziale Bibliotheksarbeit, Arbeit mit AV-Medien. Hauptstudium Wissenschaftliche Bibliotheken: Bestandsaufbau und Erwerbung, Sacherschließung, Formalerschließung, Bibliographie und Informationsvermittlung, Bibliotheksinformatik, Information und Dokumentation.

15 Praktika sind in beiden Studienrichtungen vorgeschrieben.

16 Diplomvorprüfung (bis zum Ende des 3. Semesters), Diplomprüfung und Diplomarbeit im 8. Semester.

178 Semester Regelstudienzeit (151 SWS)

18 Diplombibliothekare, Dokumentare, Buchhändler, Verlagsmitarbeiter, Berufsschullehre (für die Ausbildung von Bibliotheksassistenten)

ACADEMIC SUBJECT:

COUNTRY:

CITY, INSTITUTION:

\author{
Library Science \\ Germany \\ Stuttgart, Fachhochschule für Bibliothekswesen (p. 46)
}

07 Diplombibliothekar; Diplomdokumentar; Musikbibliothekar an öffentlichen Bibliotheken

08 1. Ebene; Vollzeitstudium

09 Allgemeine oder fachgebundene Hochschulreife

11 Mitte Oktober

12 Handlungskompetenz für alle Aufgaben an öffentlichen Bibliotheken, einschließlich Leitung.

13 Das Studium erstreckt sich auf 6 Semester, diese sind untergliedert in Grund- (1. und 2. Semester) und Hauptstudium (3. bis 6. Semester) 
14 Das Hauptfach ist Bibliothekswissenschaft, es wird aus einem allgemeinen Pflichtteil und drei Wahlprogrammen gebildet. Das Nebenfach besteht aus einer bibliotheksbezogenen Wahlwissenschaft.

15 Insgesamt 14 Wochen zwischen den Semestern in Bibliotheken und sonstigen bibliothekarischen Einrichtungen

16 In jedem Semester sind schriftliche und/oder mündliche Prüfungen abzulegen. Am Ende des Studiums ist eine Diplomarbeit anzufertigen.

176 Semester

18 Diplombibliothekar in öffentlichen und wissenschaftlichen Bibliotheken

\section{ACADEMIC SUBJECT: COUNTRY: CITY, INSTITUTION:}

\author{
Library Science \\ Italy \\ Roma, Università degli Studi di Roma "La Sapienza" \\ (p. 49)
}

07 Diploma per Bibliotecari

09 Essere già in possesso di una laurea.

105 novembre; Senza limitazione di numero

11 Secondo la data di inizio di ciascun corso di studi (novembre).

12 La Scuola si pone come l'unica struttura scientificio-educativa a livello universitario dentro la quale i bibliotecari italiani, gli attuali e i futuri, hanno la possibilità di conoscere, di dibattere, di approfondire e di far quindi progredire le discipline che competeno alla loro professione, e la cui conoscenza è indispensabile perché organismi complessi come le biblioteche possano funzionare in modo appropriato ed efficace.

14 Sono insegnamenti fondamentali del Corso di diploma per Bibliotecari: Bibliologia; Bibliographia; Biblioteconomia (biennale); Elementi di diretto per archivisti e bibliotecari; Paleografia latina; Tecnica dei cataloghi e classificazione

15 La formazionie teorica e altresi integrate con esperienze practiche ed applicative.

1610 esami di singole materi, più la discussione della tesi

1710 per ciascun diploma

18 Archivisti o Bibliotecari o altre 
! Della scuola speciale (=Facultà) per Archivisti e Bibliotecari:

Corso di diploma per Archivisti paleografi

Corso di diploma per Conservatori di Manoscritte

$\begin{array}{ll}\text { ACADEMIC SUBJECT: } & \text { Library Science } \\ \text { COUNTRY: } & \text { The Netherlands } \\ \text { CITY, INSTITUTION: } & \text { Deventer, Rijkshogeschool IJselland (p. 53) }\end{array}$

07 Diploma in Library Science/Documentation

08 1st level; full-time

09 A-level. No limitation.

10 First of December until first of June of each year.

11 First of September

12 To train students for professional functions in all types of libraries and documentation centres. Characteristic for the educational programme is the accent placed on professionalism and the attention paid to increasing knowledge of and interest in scientific and cultural aspects.

13 The curriculum is divided into subject areas which are further sub-divided into modules. These are complete subject units which are concluded with a test. Every modul has a study load of 40 hours or a multiplication thereof; most are 80 hours.

14 General Theory of Information Provision; Communication; Storage and Retrieval; Management; Cultural Knowledge; Information Science; Practical Training in the field (Museums, Archives, Documentation, Public Information)

15 Practical studies are intended.

16 Exams at the end of each term.

17 Four years (eight terms)

18 Working environments also in large and medium businesses, corporate industrial organizations and organizational advisory bureaus and chambers of commerce. 


\begin{tabular}{ll} 
ACADEMIC SUBJECT: & \multicolumn{2}{l}{ Library Science } \\
COUNTRY: & Poland \\
CITY, INSTITUTION: & $\quad$ Kraków, Uniwersytet Jagiellónski (p. 57)
\end{tabular}

07 Diploma in Librarianship

11 Competitive examination is arranged on the beginning of July.

14 Information Source, Libraries Management, Readership and Reader, Books and Librarians in Culture, Cataloguing, Methodology of Librarianship, Information Systems, Librarianship, Sources of Librarianship Studies, Contemporary Literature, Seminar

16 To complete the postgraduate school the student are required to write a paper of ca. 15 20 pages and to pass five examinations.

171 year

! Participants of the Postgraduate School are charged a tuition fee.

ACADEMIC SUBJECT:

COUNTRY:

CITY, INSTITUTION:

\author{
Library Science \\ $\infty$ Spain \\ Madrid, Universidad Complutense de Madrid (p. 73)
}

07 Diplomatura en Biblioteconomía y Documentación

09 Diplôme de fin d'études secondaires et année préuniversitaire ou Formacion Profesional (F. P.)

12 L'objectif est d'apporter un enseignement archivistique aux étudiants en bibliothéconomie et;ou en sciences de l'information et de sensibiliser d'éventuels intéressés (ex: les historiens) aux problèmes des archives et de l'archivistique.

133 ans à temps plein soit 1800 heures dont $75 \%$ de conférences et $25 \%$ de travaux pratiques.

14 Sujets généraux: Histoire (100h), Droit et économie (50h), Archéologie et monuments historiques $(50 \mathrm{~h})$, Sciences de l'Information $(1100 \mathrm{~h})$, Bibliothéconomie $(450 \mathrm{~h})$, Littérature (50h)

$17 \quad 3$ ans 


\section{ACADEMIC SUBJECT: Library Science \\ COUNTRY: \\ CITY, INSTITUTION \\ Salamanca, Universidad de Salamanca (p. 74)}

07 Diplomado en Biblioteconomía y Documentación

08 Etudes secondaires; Graduate; full-time

09 Etudes secondaires et cours pré-universitaire (4 ans).

12 L'objectif est de former des archivistes professionnels appelés à travailler dans le secteur public ou dans le secteur privé, de former des gestionnaires de documents et du personnel de conservation.

133 ans à plein temps soit 1400 heures dont $60 \%$ de conférences et $40 \%$ de travaux pratiques.

14 Sujets généraux: Histoire (80h), Droit et Economie (80h), Sciences de l'Information (80h), Bibliothéconomie $(80 \mathrm{~h})$, Informatique $(80 \mathrm{~h})$, Langages Documentaires $(80 \mathrm{~h})$, Bibliographie $(80 \mathrm{~h})$

$17 \quad 3$ ans

ACADEMIC SUBJECT: COUNTRY:

CITY, INSTITUTION:

\author{
Library Science \\ Switzerland \\ Genève, Ecole Supérieure d'Information Documentaire \\ (p. 78)
}

07 Diplôme en Bibliothéconomie, Documentation et Archivistique

09 Être porteur d'un certificat de maturité suisse ou d'un titre jugé équivalent obtenu, au minimum, après 12 ans de scolarité. Candidature sur dossier: être âgé de 23 ans; avoir exercé une activité professionelle pendant au moins 3 ans; attester de la connaissance d'une langue étrangère autre que la langue maternelle, par un résultat officiel (Cambridge First certificate, Goethe Institut, etc.) Une des deux langues doit être le français; rédiger une biographie manuscrite de motivation.

$1015 \mathrm{Mai}$

11 Début Octobre de chaque année.

12 Le bibliothécaire-documentaliste-archiviste (BDA), professional de l'information documentaire, est un médiateur, un intermédiaire privilégié, entre le document, ou l'information contenue dans le document, et l'usager qui a besoin de cette information. 
Le BDA est formé à gérer l'information contenue dans les documents, à assurer son transfert. Il ne la crée généralement pas, mais l'organise pour la rendre accessible à ceux qui l'utiliseront.

14 Approche Globale; Bibliologie; Acquisition et Développement des Fonds; Description Bibliographique; Analyse Documentaire; Communication; Bibliographie et Référence; Diffusion de l'Information; Marketing/Promotion; Dactylographie et Secrétariat; Informatique et Informatique Documentaire; Gestion; Synthèse.

154 stages (7 mois) sont prévus; les stages sont organisés par l'école. Travail dans un service d'information documentaire.

16 Examens sont intégrés à l'enseignement. Les dates sont variables.

$17 \quad 3$ ans

18 Bibliothécaires dans toutes les institutions; documentalistes dans entreprises privées.

! Les étudiants répondant aux conditions fixées par la loi sur l'encouragement aux études bénéficient de l'exemption de la taxe d'écolage, pour autant que leur demande de remboursement soit remplie correctement.

\author{
ACADEMIC SUBJECT: Library Science \\ COUNTRY: \\ CITY, INSTITUTION: Sheffield, University of Sheffield (p. 93)
}

07 Master of Arts (MA) in Librarianship

08 2nd level; full-time

09 Applicants for this programme will be normally expected to have a good Honours degree (Class 2 or higher) in any discipline, and to have had a year of practical experience in a library or information unit before joining the Department.

10 Early application is advised, preferably before 31 st December for a place on the programme starting in October of the following year.

11 October of each year.

12 The MA in Librarianship Programme prepares graduates for a wide range of careers in the libraries of universities and other institutions of higher education, the public library service, government libraries, special libraries and research. The programme introduces students to the principles, disciplines and skills essential for the successful practice of Librarianship and Information Handling. 
14 Term 1: non-elective courses: Libraries, Information and Society I; Computers and Information I; Information Resources I; Information Storage and Retrieval; Management I; Term 2: non-elective courses: Computers and Information II; Library Automation; Information Resources II; Libraries, Information and Society II; Management II (Human Resource Management); Term 2: elective courses: Advanced PASCAL; Aspects of Collection Management; Business Information; Community Information; Database Design; Graphical Art and Visual Communication; Health Care Information Service; Historical Bibliography; Information Storage and Retrieval; Marketing, Promotion and Public Relations for Library and Information Services; People Skills; Term 3: An intensive, unexamined, one week course in statistical methods and survey is offered to assist students with dissertation projects requiring statistical skills.

15 Visits are organized to important libraries, information services and similar institutions. Students are required to attend all visits.

16 Work on each course is subject to an appropriate form of assessment which include continuous assessement. Great importance is attached to coursework and a satisfactory standard in this is an essential requirement for the award of this degree. There is no general formal examination. Each student is required to complete a dissertation in the period from end of April to September first.

$17 \quad 1,5$ years

18 In addition students are finding work in the increasing number of posts requiring similar skills outside the established library and information services sector.

ACADEMIC SUBJECT:

COUNTRY:

Strategic Library Management

CITY, INSTITUTION:

10 United Kingdom

Manchester, Manchester Metropolitan University (p. 91)

07 Master of Arts (MA) in Strategic Library Management

08 2nd level; part-time

11 Because of limitations on resources, the next intake being in October 1994.

12 The course aims, therefore, to provide a management development programme that will enable librarians and related professionals to cope with change and to design and implement changes. The course has two broad aims: a) to provide an appropriate management development programme for librarians and related professionals, leading to a higher degree; b) to make a contribution to the more effective management of libraries and information systems, through student projects.

14 In the first year the course aims to provide a theoretical basis of organization studies and research methods. The second year comprises two double modules presenting a series of 
case studies. These case examine technological and other changes affecting libraries, such as new information technologies, income generation, new library and information needs in the community, and so on.

16 There are no written examinations.

172 years

! At the time of writing, the fees are $£ 182$ per year, including tuition fee and CNAA registration fee. 